Portland State University

PDXScholar

\title{
John Chrysostom, On the statues : a study in crisis rhetoric
}

Douglas B. Radke

Portland State University

Follow this and additional works at: https://pdxscholar.library.pdx.edu/open_access_etds

Part of the Speech and Rhetorical Studies Commons

Let us know how access to this document benefits you.

\section{Recommended Citation}

Radke, Douglas B., "John Chrysostom, On the statues : a study in crisis rhetoric" (1988). Dissertations and Theses. Paper 4051.

https://doi.org/10.15760/etd.5935

This Thesis is brought to you for free and open access. It has been accepted for inclusion in Dissertations and Theses by an authorized administrator of PDXScholar. Please contact us if we can make this document more accessible: pdxscholar@pdx.edu. 
AN ABSTRACT OF THE THESIS OF Douglas B. Radke for the Master of Arts in Speech Communication presented April 29, 1988.

Title: John Chrysostom: on The statues

A study in Crisis Rhetoric.

APPROVED BY MEMBERS OF THE THESIS COMMITTEE:
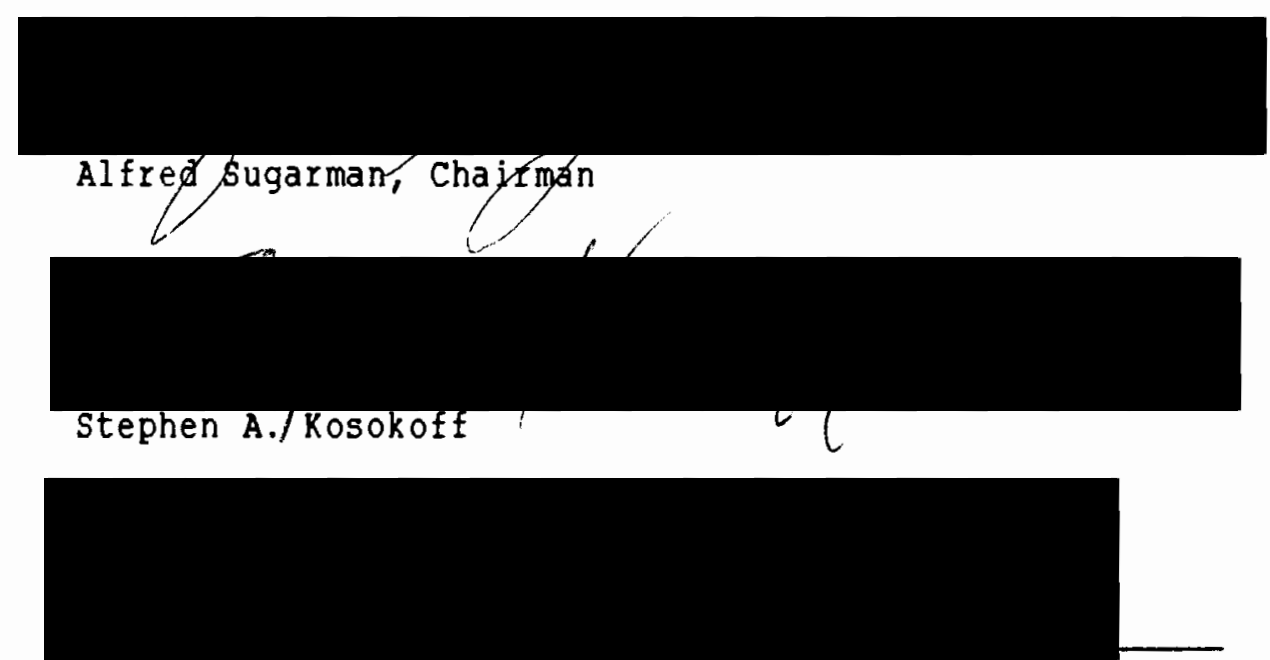

Peter Ehrenhaus

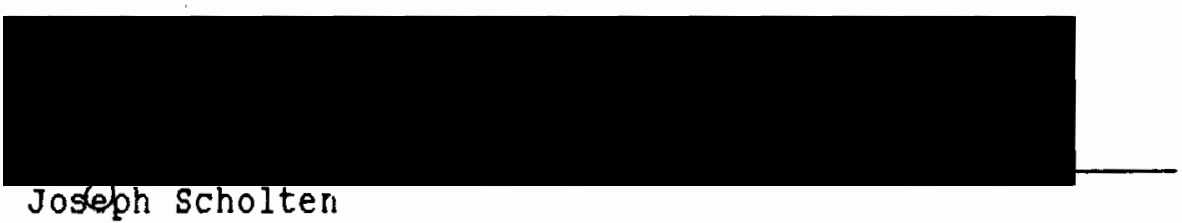

The name of John Chrysostom has historically been held in high esteem by the Christian Church. John was born, circa A.D. 350, in the syrian city of Antioch. His rhetorical career led him to the apex of religious power as bishop of Constantinople. As a result of his verbal harangues of the political and religlous leaders, he was sent 
into exile, where he died in A.D. 407. During his life time he was recognized both for his eloquence and his controversial style. Since the fifth century he has been remembered by the epitaph "Chrysostom," a tribute to his oratorical abilities, which translated means "the golden mouthed."

A significant factor in John's escalating career was his preaching response to a major political and social crisis at Antioch in A.D. 387. Revolting over an increase in taxes, the citizens of the city had committed an act of open treason by pulling down the statues of the Emperor Theodosius and his family. Many fled the city to escape the impending wrath of the Emperor. Others packed the church, hoping to hear words of guidance and comfort.

During the weeks of uncertainty, John delivered twenty-one homilies entitled on The statues in which he directly dealt with the circumstances of the crisis. The research task of this thesis was to analyze the characteristics of Chrysostom's crisis rhetoric as found in these sermons.

The writer consulted both primary and secondary sources in investigating the life, times, and rhetoric of the Antiochene priest. since many of the secondary sources exhibit a definitely favorable bias toward the ancient orator, the major focus of the writer's research centered on John's own homilies as translated from the Greek.

In this analysis, attention was given to understanding the various political, social, economic, religious, and rhetorical factors which combined to provide a uniquely turbulent context for John's preaching. 
The writer examined ten selected homilies from the series, on The statues. Drawing from a dramatistic perspective of rhetorical criticism, the author applied the framework of Ernest Bormann's Fantasy Theme Analysis to John's crisis rhetoric. In this study five recurring themes were identified as being significant components in John's rhetorical vision. Through his highly dramatized messages complete with heroes and villians, John communicated his view of "social reality" by interpreting to his audience the spiritual meaning he saw in the events of the crisis. His rhetoric was characterized by the use of dichotomies such as God and satan, good and evil, heaven and hell, Christian and pagan, and rich and poor. The crisis was a time for genuine repentance and social and spiritual reformation. He was convinced that if God's people responded appropriately then the evil of the crisis would be transformed into great spiritual blessing. In John's mind, the church was responsible for preventing crises by aggressively attacking, even with physical violence, the evil blasphemers who were threatening society.

The writer concluded that John, in the light of the rhetorical ethics of the fourth century, was a skilled communicator. The author also discovered that the ancient rhetor was highly inconsistent when evaluated by his own belief system. Tle volatile messages of the "Golden mouthed" certainly nurtured prejudice and divisiveness, leading this writer to conclude that John may have even been partially responsible for precipitating, or at least fueling, the very crisis he sought to resolve through his homilies. 


\title{
JOHN CHRYSOSTOM: ON THE STATUES
}

\section{A STUDY IN CRISIS RHETORIC}

by

DOUGLAS B. RADKE

A thesis submitted in partial fulfillment of the requirements for the degree of

\author{
MASTER OF ARTS \\ in \\ SPEECH COMMUNICATION
}

Portland State University 
TO THE OFFICE OF GRADUATE STUDIES:

The members of the Committee approve the thesis of Douglas

B. Radke presented April 29, 1988.

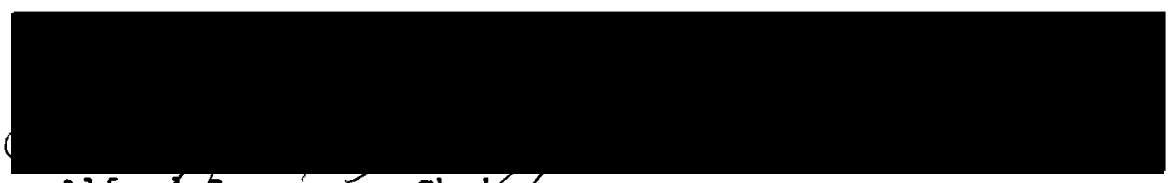

Alered sugarman, chajrman

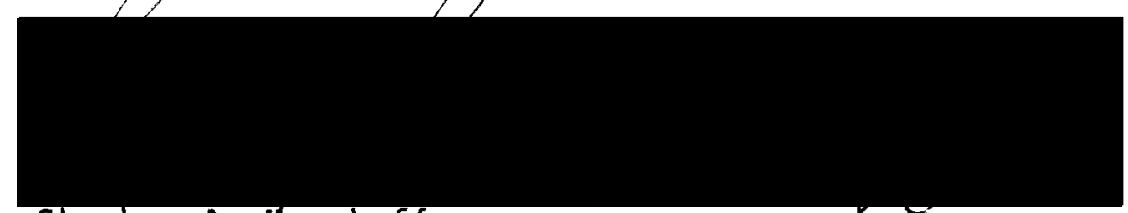

Stephen A. Kosokoft

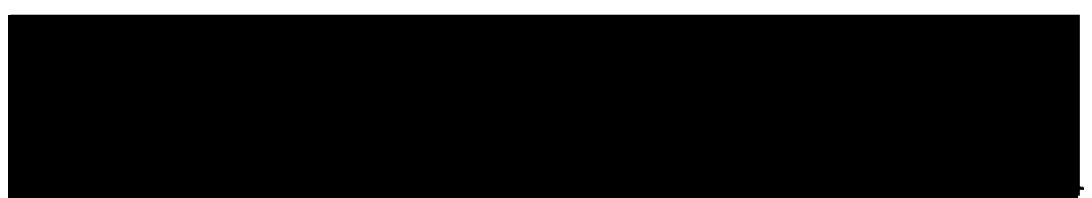

Peter Ehrenhaus

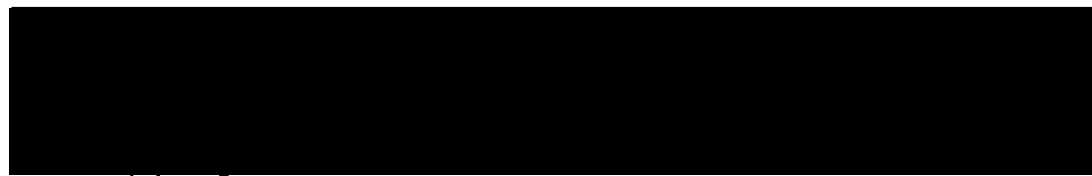

Josegb Scholten

APPROVE :

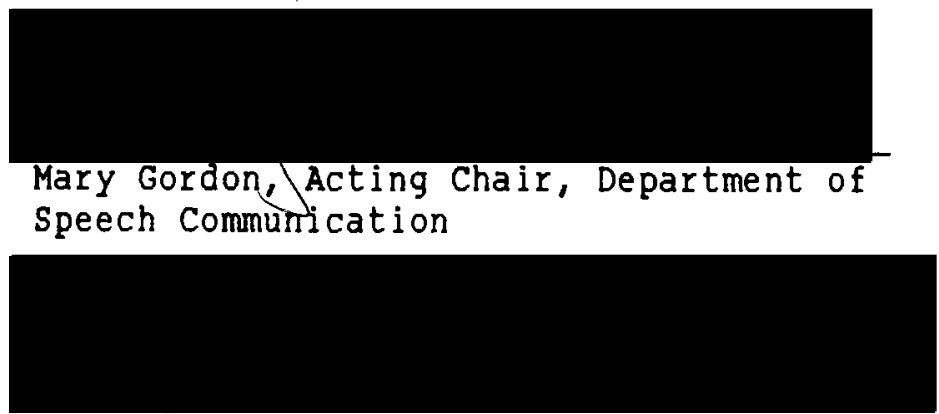

Bernard Ross, Vice Provost for Graduate

studies 


\section{ACKNOWLEDGEMENTS}

There are many people who have helped to make this thesis a reality and who are deserving of a few words of appreciation. The members of my advisory committee have all played significant roles in the process of this endeavor. Thank you, Dr. Kosokoff, for afflrming my thesis topic. Thank you, Dr. Ehrenhaus, for challenging me to critically examine my methods of research. Thank you, Dr. Scholten, for reviving my interest in the tools of historical study. Most of all, thank you, Dr. Sugarman for your constant encouragement and that sense of accountability to keep me on schedule.

This year of study and writing has been a unique and sometimes draining experience for my family. I am keenly appreciative of your patience, forgiveness, and motivating encouragement that have made this step possible. Thank you, Betty Rae for all the sacrifices you have made and all the help you have provided. To Dan, Lisa, Trisa, and Erin, I love you and I am grateful for your understanding and your supportive curiosity concerning my academic pursuits.

Th1s thesis is dedicated to the memory of my father, Merlin E. Radke, whose eloquence was displayed not in flowery words of rhetoric, but in visible and lasting expressions of love. 
TABLE OF CONTENTS

PAGE

ACKNOWLEDGEMENTS .

\section{CHAPTER}

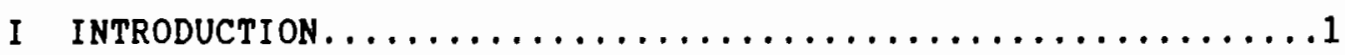

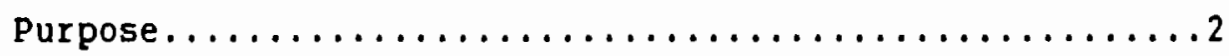

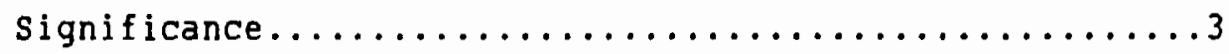

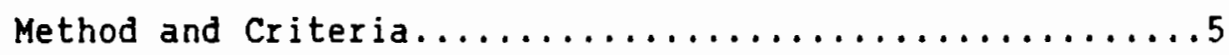

Sources.................................

Literature Review...........................

Procedure...............................

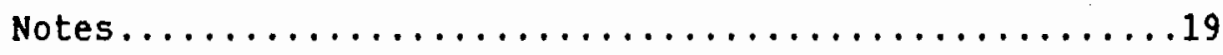

II JOHN CHRYSOSTOM: THE SPEAKER $\ldots \ldots \ldots \ldots \ldots \ldots \ldots \ldots \ldots \ldots \ldots$

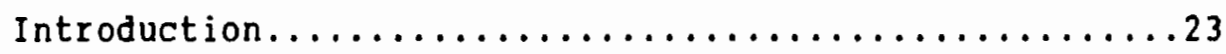

His Early Years................................

His Ascetic--Monastic Quest.................... 32

His Public Life in Antioch.................... 55

His Leadership as Bishop of Constantinople...........36

His Exile and Death........................ 40

His Character...........................

Notes............................... 45

II JOHN CHRYSOSTOM: HIS RHETORICAL IMPERATIVES $\ldots \ldots \ldots \ldots \ldots 48$

Introduction. . . . . . . . . . . . . . . . . . . 
The Changing Roman Empire..................50

The Cosmopolitan City of Antioch...............60

The Church in Antioch....................69

The Riot of A.D. $387 \ldots \ldots \ldots \ldots \ldots \ldots \ldots \ldots \ldots \ldots \ldots$

Notes................................

IV JOHN CHRYSOSTOM: HIS RHETORICAL PURPOSES $\ldots \ldots \ldots \ldots \ldots \ldots . \ldots 82$

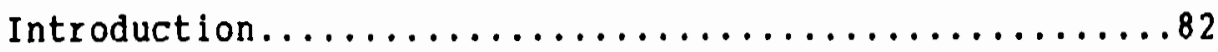

Homilies...........................84

summary.............................

Notes...................................

V JOHN CHRYSOSTOM: HIS RHETORICAL VISION............112

Introduction. ..........................

Crisis: A Supernatural Drama.................115

Crisis: A Transformational Drama.................119

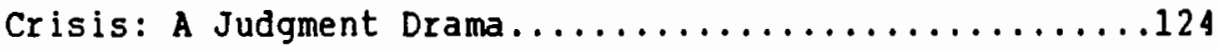

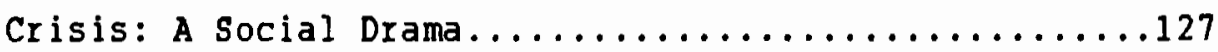

Crisis: An Evangelistic Drama......................

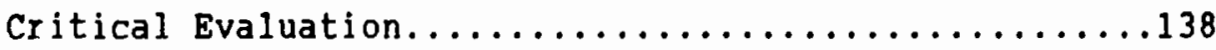

Summary...............................

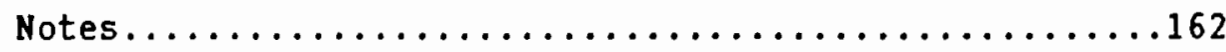

VI JOHN CHRYSOSTOM: CONCLUSIONS ON HIS CRISIS RHETORIC.....167

summary................................ 167

Implications of study...................181

Suggestions for Further study...............186

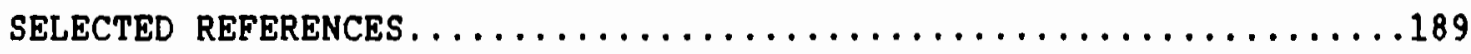

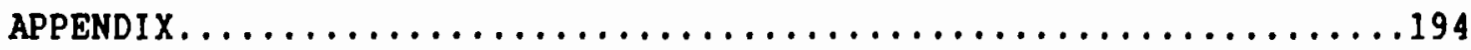


CHAPTER I

\section{INTRODUCTION}

In February, A.D. 387, the Syrian city of Antloch was rocked by a serles of events that created a unique rhetorical climate for a young priest by the name of John. Certain citizens of the city, upon hearing news that extra taxes were to be levied against them, had reacted by rioting in the streets. They further vented their anger and frustration by pulling down the statues of the Emperor Theodosius and his recently deceased wife Flacilla and dragging them through the streets of Antioch.

Government troops moved quickly against the mob, killing some and arresting others. In a few hours the riot was quelled. Both the guilty and the innocent citizens of Antioch were paralyzed by the fear of what their insulted Emperor might do in retallation. In their panic many flooded into the church where John had recently been appointed as pastor. These crowds were a receptive audience for John's rhetorical response to the crisis.

John delivered a series of twenty-one Lenten homilies, entitled en The Statues, during the days of uncertainty as the people anxiously waited to see if Theodosius would react in anger or forgiveness. John's audience vacillated from hope to extreme despair as rumors circulated throughout the city. John sought to encourage and strengthen the troubled masses that packed the church. He also 
repeatedly attempted to persuade his listeners to change their life styles as he taught them what he felt were the important spiritual lessons inherent in the tragic crisis. Even after the news arrived that Bishop Flavlan had successfully appealed to the Emperor to respond with mercy, John continued to challenge the citizens of Antioch to overcome the moral and spiritual apathy that he belleved had precipitated the calamity.

John's homilies, on the Statues, provided an excellent display of his oratorical ability and the apparent success of his sermons gave impetus to his escalating career. Among his contemporaries John earned a reputation as a gifted, sometimes controversial, communicator. Some 150 years after his death he received the surname "Chrysostom," a tribute to his rhetorical eloquence, which translated from the Greek means: "the golden-mouthed." Church historians over the centuries have praised his speaking skills. For example, according to Phillp Schaff, John became "the greatest pulpit orator and commentator of the Greek Church, and still deservedly enjoys the highest honor in the whole Christian world. ${ }^{2}$

\section{PURPOSE}

It is the purpose of this thesis to analyze the characteristics of the crisis rhetoric of John Chrysostom in his homilies, on The statues.

This study does not attempt to cover all of the rhetorical dimensions of John's homilies. I have chosen primarily those materials from the entire series of homilies which best reflect John's 
rhetorical vision of the crisis itself. Attention is focused on the specific rhetorical themes and devices employed by John in both interpreting the crisis to his audence and persuading them to respond to his appeals.

\section{SIGNIFICANCE}

The character and rhetoric of John Chrysostom provide ample material for a significant chapter in the history of the Christian Church. His influence was certainly felt in the turbulent religious, political, and social context of his own lifetime. Because of his reputed communication skills many of his homilies, commentarles, and other treatises were preserved in written form. Through these materials his ideas and the mystique of his personality have been kept allve. At varlous times in history, especially the Middle Ages, his words have been admired, studied, and emulated.

The mafority of the writers on the life of Chrysostom do not apply the principles of rhetorical criticism to his homilies. In general the works are inspirational in tone and portray John in saintly terms. They do not seek to evaluate how John may have precipitated or fueled the crisis by his sermons. A critical analysis of his rhetorical vision of crisis is needed. This study will fill an important gap in the research and writings on John's preaching.

Tucker emphasizes the value of historical-critlcal research by stating that such research expands one's world experience by "providing a deeper appreciation and more thorough insight into the essential nature and uniqueness of people and events." ${ }^{3}$ Th1s thes is 
explores the unique factors that shaped John's rhetorical vision. This study also examines the context of John's crisis rhetoric in order to understand his audience and their apparent enthusiastic response to his preaching. An historical-crltical study of John's homilies will, also, prove instructive in understanding the dynamics of crisis rhetoric in both the fourth century and the contemporary scene.

Studies in rhetorical criticism emphasize the important role crises have played in producing great oratory. In describing this interrelationship of distinguished oratory and social crisis, Thonssen, Baird, and Braden quote the words of Ralph Waldo Emerson: "Times of eloquence are times of terror." They also write:

The stress of events assoclated with man's quest for freedom in civil and political life, the upsurges of patriotic fervor occasioned by man's deslre to preserve his rights or to extend the influence of his power--these and other manifestations of the human will have always dominated the scene during those periods most productive in public address.

Andrews observes that "great oratory often grows out of a series of events that either precipitate a crisis which calls for immediate action or delineates [sic] a serlous problem which demands a solution." ${ }^{5}$ The research that has been done to examine this crisis influence upon religious rhetoric is very limited. The situation in Antioch and John's rhetoric before, during and after the crisis provide a clear historical context for studying this concept.

The historical role of John Chrysostom, the limited critical studies on his rhetoric, the value of historical-critical research, and the significant link between crisis and rhetoric together provide important justification for this thesis. 
METHOD AND CRITERIA

This thesis utilizes an historical-critical framework in analyzing the crisis rhetoric of John Chrysostom presented in the homilies, on The statues. That framework includes an analysis of: 1) the speaker, 2) the rhetorical imperatives that provided a context for the speeches, 3) the speaker's rhetorical purposes, 4) the themes he developed in relationship to the crisis, and 5) a critique of $h$ is strengths and weaknesses as an orator.

\section{The speaker}

A blographical sketch of Chrysostom's life provides a number of insights into both his ethos and effectiveness as a speaker. In order to understand his rhetorical response to the Antiochene crisis, it is vital to identify key elements in his family background, rhetorical training, religious development, and personal temperament. This thes is explores these elements in some detail.

\section{Rhetorical Imperatives}

Thonssen, Baird, and Braden emphasize the importance of studying the rhetorical context critically. They write:

...public address functions within the framework of a social and political milieu...the criticism of it must be soundly based upon a full and penetrating understanding of the meaning of the events from which it igsues and of the listeners who pause to consider what is said.

$$
\text { Andrews coins the term "rhetorical imperatives" in describing }
$$

the historical, political, social, and cultural events and values which demand a response from the speaker. He writes: 
...rhetoric grows out of events that a speaker wants us to see as important. Historical and political events and trends can force certain issues into our consciousness; the situation can 7 make it imperative that we somehow come to grips with issues.

One cannot begin to understand John's response to the riot without identifying the various forces at work in the city of Antioch. The political, social, and religious tensions created the very imperative Andrews describes. The urgency of the situation opened the ears of the audience to hear and respond to words they may have otherwise ignored. The changing relationship of church and state at the end of the fourth century also gave John a new platform of power and influence from which to speak. These imperatives are discussed in detail in this thesis.

\section{Rhetorical Purposes}

A rhetorical message is a purposive message; its goal is to bring about a certain response from an audience. In discovering this purpose, the critic needs to examine the events behind the speech, the speaker's own position and background that caused him or her to speak out, what the speaker actually states concerning his or her purpose, and what comes through the speech as an unstated purpose. 8 John had definite purposes in mind as he spoke to his audience. These purposes, clearly expressed or subtly implied, strongly influenced the way John chose to construct and deliver his sermons. This thesis probes these purposes in analyzing John's rhetoric. 


\section{Rhetorical Themes}

This study applies a dramatistic framework of rhetorical analysis to John's homilies. The proposition that "life is like a drama" is especially applicable in evaluating John's sermons. The dramatistic model visualizes persons as actively involved in creating and communicating their views of social reality. The dramatistic model generally focuses on: 1) the actor who communicates through verbal and nonverbal symbols, 2) the spectators/actors who seek to interpret and respond to the message, and 3) the meanings and actions that are produced in cultural and subcultural settings. ${ }^{9}$ In the context of this study, John the actor, delivered his dramatic scripts in the presence of spectators, who shared a common world view with their preacher and who also acted in response to familiar Biblical cues and imperatives. In this thesis I focus on these dramatized elements in John's rhetoric by applying the methodology of fantasy theme analysis to selected homilies from on The statues.

In his book, The Force of Fantasy, Ernest Bormann introduces the concept of fantasy theme analysis in discussing the "way members of a rhetorical community, who share the same consciousness and rhetorical vision, discuss their problems, concerns, delights, hopes, fears, and dreams." 10 Fantasy theme critics use a unique vocabulary in describing the process through which communitles develop and communicate their rhetorical dramatizations. Some of the key terms in their analytical taxonomy are fantasy, fantasy theme, symbolic cues, fantasy type, and rhetorical vision. Bormann defines these concepts as follows: 
Eantasy. "The creative and imaginative interpretation of events that fulfills a psychological or rhetorical need." 11

Fantasy Theme. "The content of the dramatizing message that sparks the fantasy chain." 12 Themes may be comprised of actual or fictlous scripts of characters and events in the group's written or oral history. In the religlous context, fantasy theme scenarios often include supernatural actors, personal testimonies of rellglous experience, vivid metaphors, and dramatized Biblical narratives.

Symbolic Cues. "When a group of people have shared a fantasy theme, they have charged their emotional and memory banks with meanings and emotions that can be set off by a commonly agreed upon cryptic symbolic cue." ${ }^{13}$ Key words, metaphors, or phrases serve as cues that trigger the recalling of the full-blown theme content.

\section{Eantasy Type. "A fantasy type is a stock scenario repeated} again and again by the same characters or by similar characters." 14

Rhetorical Vision. "A rhetorical vision is a unified puttingtogether of the various scripts which gives the participants a broader view of things." 15

Bormann lllustrates his analytical framework by identifying a number of recurring themes in the sacred-secular rhetoric of early American history. He discusses how the rhetorical portrayal of a time of national crisis may be used by the speaker to foster a sense of unity and purpose in the midst of impending trouble. For example, he analyzes and compares the rhetorical vision of the Puritan preachers during the time of the revolution with that of Abraham Lincoln during the civil War years. He concludes that in both settings of crisis, 
speakers developed and communicated the theme that God would bring good out of the present evil if people would repent and reform their ways. $^{16}$ I utilize Bormann's concept of theme analysis in analyzing the varlous themes developed by Chrysostom in his homllies, on.The statues. Chrysostom consistently emphasized a pattern of themes which reflected his own rhetorical vision and which reinforced the vision of the sacred community to which he and his audience belonged.

\section{Rhetorical critique}

In addition to describing the characteristics of John's crisis themes, I am concerned in this thesis with questlons regarding the quality, effectiveness and appropriateness of his rhetoric and the possible impact of his words upon the Antiochene audience. I focus attention on these issues by examining the possible strengths and weaknesses of John's communicative response to crisis.

As a part of this critique the following classical canons of rhetorical criticism: 1) invention, 2) arrangement, 3) style, and 4) delivery, are specifically applied to the crisis material found in selected homilies from on the statues. It is beyond the scope of this study to apply these canons to all that John said in his twenty-one homilies. However, the following four questions are of significant concern in analyzing John's effectiveness as a rhetorician: 1) What modes of proof did John use in framing his arguments and appeals when speaking about the crisis? 2) How did John arrange his materials in order to capture and hold the attention of his audience? What might have been the impact on his audience of his selective placement of 
references to the crisis within the overall context of his homllles? 3) What words, figures of speech, metaphors, and comparisons did John use in describing the crisis and developing his themes? 4) How did John's manner of dellvery relate to his crisis material?

To summarize: this thesis critically analyzes the characteristics of John's crisis rhetoric as found in on The statues by examining John the speaker, his rhetorical context, his rhetorical purposes, and his rhetorical themes and devices.

\section{SOURCES}

\section{Primary Source Material}

The English translation of On The Statues, by W.R.W. Stephens, is used in studying John Chrysostom's homilies. ${ }^{17}$ There is some debate as to the actual order of the recorded homilies. ${ }^{18}$ This minor textual concern, however, has little bearing on this particular study. The texts of the twenty-one homllies have been well preserved through history. It is believed that John delivered his homilies extemporaneously. They were probably preserved in shorthand by the reporters of his time, revised by him, and later published with his consent. ${ }^{19}$ Church historlans have preserved much of the material attributed to Chrysostom and it is avallable in English translation. Some of these additional writings, taken from Schaff's Nicene and PostNicene Fathers, are referred to in this thesis. ${ }^{20}$ 


\section{Selected Homilies}

From the twenty-one homilies, ten have been specifically selected for careful analysis. These ten homilles were chosen because: 1) they contained a greater percentage of crisis material, 2) they were delivered at critical times during the crisis, and 3) they best represented the themes repeatedly developed by John throughout the other homilies. In brief, the ten selected homllies are as follows:

Homily I. Delivered about a week before the rlot. Tensions were beginning to build over the tax situation. Chrysostom graphically instructed his audience regarding what they should do in response to those causing the dissent.

Homily II. Delivered about one week after the riot. Chrysostom kept silent for a number of days following the riot while the city grieved over its predicament. With tensions at a fever pitch, John broke the silence and spoke for the first time about the calamity.

Homily III. Delivered the day after Homily II. John dealt with the death of those who were killed as a result of their participation in the riot. He instructed the people how they should behave while they were waiting to see if the Bishop would be successsful in persuading the Emperor to be merciful.

Homily $v$. Delivered a few days later. John emphasized perseverance in response to the impending wrath of the Emperor.

Homily VI. Delivered the day following $V$. John spoke about an appropriate fear of magistrates, suffering, and martyrdom. He used a 
number of Biblical examples to stress the importance of falthfulness in crisis.

Homily XIII. Delivered about two weeks after VI. A climax to three homilies on thanksgiving after the crisis seemed to be over.

Homily XV. Delivered two days later, after fears were renewed. Rumors were circulating that soldiers were coming to punish the citizens of Antioch.

Homily XVI. Delivered the next day, after the chief official of the city had entered the church to quiet the anxious crowds about the rumors of impending destruction. John was incensed that the people had so little faith that it was necessary for the pagan official to address them and chastise them for their fears.

Homily XVII. Delivered two days later in response to the arrival of commissioners from the Emperor who were sent to investigate the insurrection. John reviewed the details of the overturning of the statues.

Homily XXI. Delivered on Easter Sunday, about three weeks after XVII. The Bishop had returned with the good news of forgiveness and the reconciliation of the Emperor with the city of Antioch. John celebrated the deliverance and reaffirmed the lessons he felt they had learned during the crisis. 


\section{LITERATURE REVIEW}

\section{Ancient sources}

In addition to John's own words the following materials provide essential data concerning the life and times of John Chrysostom.

secular. In the later part of the fourth century, Ammianus Marcelilinus ${ }^{21}$ wrote a history of the Roman Emplre from A.D. 98-378. of his original thirty-one books only Books XIV-XXXI have survived. These documents focus on the period from A.D. 353-378. Ammianus does not mention John. His writings end before the time of the crisis in Antioch. He does provide critical historical material from the time period. He was also a close friend of Libanius who was responsible for teaching rhetoric to Chrysostom. Ammianus demonstrated care in preserving an accurate account of events and of the personalities involved. He was a pagan. His religious convictions, however, did not highly color his accounts. His praise of the pagan Emperor Julian was balanced with criticism when appropriate. His criticisms of Christians focused on their fallure to live up to their own codes of morality.

Writing in the fifth century, zosimus ${ }^{22}$ recorded a history of the decline of Rome from Augustus to A.D. 410 in six books, all of which have survived. He utilized a wide variety of sources including Dexippus, Eunapius, and 0lympiodorus. His knowledge of Eastern events was greater than his grasp of Western happenings. A number of criticisms have been leveled against zosimus concerning his style, carelessness, and prefudice. His bias against the Church was 
vehemently expressed in his writings. He was silent about John's role when describing the riot in Antioch. He later portrayed John Chrysostom as a demogogue bringing chaos and destruction to Constantinople in A.D. 104. His writings provide some balance to the overly favorable press given to the Christian Emperors and religious leaders of the time period. No doubt, the truth lies somewhere between the extreme position of zosimus and that of the ecclesiastical historians of the time period.

Libanlus ${ }^{23}$, John's teacher of rhetoric, also provides a wealth of materlal on the city of Antloch and the state of rhetorlc in the fourth century. A considerable number of his orations have survived which provide a unique commentary on the events surrounding the riot of A.D. 387. Llbaniug was an outspoken pagan and strong critic of the Church. His rhetoric is representative of the second Sophistic Perlod. Sozomen, quoting Libanius wrote: "When this sophist was on his death-bed he was asked by his friends who should take his place. 'It would have been John,' replied he, 'had not the Christians taken him from us. 124

Ecclesiastical. Early in the fifth century, Palladius ${ }^{25}$ wrote a dialogue on the life of John. As a close friend of the controversial priest he sought to set the record straight on the details of his life, especially the charges brought against him which led to his exile and death. Because of his deep loyalties to John he was somewhat biased in his evaluation of events.

Socrates Scholasticus ${ }^{26}$, writing in middle of the fifth century, devoted nearly a chapter to the life of John In his history of the 
Church from A.D. 305-439. He seemed to lack accurate information in some matters and is reliable only when he is supported by other sources. He was apparently not aware of the Dlaloque of Palladius. Sozomen ${ }^{27}$, who also wrote in the fifth century, depended considerably upon socrates in presenting his historical account of the Church from A.D. 323-425. He had some additional sources at his disposal when writing about Chrysostom, to whom he devoted a number of chapters. He was more accurate and better informed than Socrates Scholasticus.

\section{Hodern Literature}

Biographical Works on Chrysostom. The majorlty of writings on John are only rephrasings or expansions of the biographies of Palladius, Sozomen, and Socrates. Written in the 1800's or early 1900 's their purpose was to inspire the reader rather than critically analyze Chrysostom's rhetoric. The classic two volume work by Reverend Chrysostomus Baur 28 is by far the most comprehensive and helpful in constructing the background and details of John's life. Attwater's ${ }^{29}$ blography is also valuable, especially his discussion of John's experience as a desert monk.

critical studies of Chrysoston. The works of Ameringer, Sawhill, and Burns examine Chrysostom's homllies from a rhetorical perspective. The major concern of ameringer is to identify the Influences of the Second Sophistic Perlod upon John's rhetorical style. 30 Sawhlll focuses upon Chrysostom's use of athletic metaphors in his preaching. 31 Burns limits her analysis to the homllies, on the statues, giving speclal attention to the influences of the second 
Sophistic Pexiod upon the observed style of John in these selected homilies. ${ }^{32}$ While these materials are helpful in analyzing specific aspects of John's rhetoric, as described above, they do not give attention to the issues of crisis rhetoric raised by this thesis.

Wilken examines John's rhetoric in relation to the Jewish community in Antloch. In addition to providing a thorough overview of Chrysostom's historical context he critically evaluates John's preaching as a "rhetoric of abuse, ${ }^{33}$ particularly his outspoken attacks against Judaism. John was silent about the Jewish community in on The statues. He did, however, identify and attack those he perceived to be responsible for bringing evil upon the city. Wilken is a valuable resource in analyzing John's frequent use of invective in his rhetoric of crisis.

General Vorks. The work of Baldwin provides a clear presentation of the rhetorical characteristics of the second sophistic Period of which John Chrysostom was a part. He discusses such elements as virtuosity, pattern, elaboration of style, and imagery. ${ }^{34}$ since Chrysostom recelved his rhetorical training in this school of oratory, this background material is essentlal for understanding his rhetorical mindset.

George Kennedy carefully analyzes the development of later Greek rhetorical theory, giving attention to such sophists as Libanius. He also traces the roots of rhetoric within Christianity and devotes one chapter to a discussion of Chrysostom. ${ }^{35}$ This is the most recent work on this perlod of rhetorical development. 
Vorks on Rhetorical Criticism. James Andrews ${ }^{36}$ presents a clear framework of analysis for the rhetorical critic. Special attention is given to the subjects of speaker, context, and audience. These topics, introduced in our discussion of methodology, apply directly to our study of the life and crisis rhetoric of Chrysostom. The classic work on rhetorical criticism by Thonnsen, Baird, and Braden 37 is, also, a helpful tool, especlally in its emphasis upon the relationship of crisis and rhetoric. Likewise, Bormann's fantasy theme perspective ${ }^{38}$ is especially valuable in identifying, cataloging, and analyzing the varlous themes that comprised John's rhetorical vision.

\section{PROCEDURE}

The purpose of this thesis is to analyze the characteristics of the crisis rhetoric of the fourth century priest, John chrysostom, as expressed in selected homilies from his series entitled, on The Statues. The thesis consists of six chapters. The first chapter introduced John and his rhetoric and contained sections on the significance of this study, the method employed, the sources utllized, and the relevant literature available. The following procedure is followed in presenting the results of this research:

\section{Chapter II--John Chrysostom: The Speaker}

This blographical chapter Includes a survey of John's childhood influences, rhetorical training, religlous conversion, and ascetic life. His career as priest in Antloch, his elevation to the position of Bishop of Constantinople and hls final days of conflict, exile, and 
death are discussed. This chapter also draws some conclusions about his personality and character traits.

Chapter IL --John Chrysostom: His Rhetorical Imperatives

This chapter examines the historical context of the crisis in Antloch. It includes a portrait of the Roman world of John's day, an analysis of the polltical, rellgious, soclal, and rhetorical climate of Antloch, a look at John's Church, and the detalls of the rlot itself.

Chapter IV--John Chrysostom: His Rhetorical Purposes

This chapter focuses on John's rhetorical purposes before, during, and after the actual riot. Stated and implied purposes are discussed.

Chapter V--John Chrysostom: His Rhetorical Vision

This chapter analyzes John's rhetorical vision by examining the various themes he developed in interpreting the crisis to his audience. The second part of the chapter is a criticial evaluation of the strengths and weaknesses of John's crisis rhetoric.

Chapter VI--John Chrysostom: Conclusions on His Cris is Rhetoric

This chapter summarizes the results of this research. Implications of this study and suggestions for further research are presented. 
CHAPTER I NOTES

1 pope Vigilius first applied the surname "Chrysostom" to John in 553. Cassian and Cassiodorus later introduced the term to the West.

2 Philip Schaff, "Prolegomena," The Nicene and Post-Nicene Fathers, 14 vols. (Grand Rapids, Michigan: Eerdmans Publishing Company, 1978) 9:5.

3 Raymond K. Tucker, Richard L Weaver II, and Cynthia BerrymanFink, Research in Speech Communication (New Jersey: Prentice Hall, 1981) 67.

4 Lester Thonssen, A Craig Balrd, and valdo w. Braden, speech Criticism, 2nd ed. (New York: The Ronald Press Company, 1970) 348. 5 James R. Andrews, The Practice of Rhetorical Criticism (New York: Macmillan Publishing Company, 1983) 7.

6 Thonssen, et al., 349 .

7 Andrews, 18.

8 Andrews, 7.

9 Bruce E. Gronbech, "Dramaturgical Theory and Criticism: The state of the Art (or Science?)," Western Journal of Speech

Communication 44 (Fall 1980): 315-336.

10 Ernest G. Bormann, The Eorce of Fantasy (Carbondale: Southern Illinols University Press, 1985) 3.

11 Borman, 5.

12 Borman, 5. 
13 Borman, 6.

14 Borman, 7.

15 Borman, 8.

16 Ernest G. Bormann, "Fetching Good Out of Evil: A Rhetorical Use of Calamity," Quarterly Journal of Speech 63 (April 1977): 130139.

17 John Chrysostom, on The statues, translated by W.R.w. Stephens in The Nicene and Post-Nicene Fathers, 14 vols. (Grand Rapids, Michigan: Eerdmans Publishing Company, 1978) vol. 9.

18 For a discussion of this textual concern refer to schaff's preface to the Homllies found on pages $317-327$ in The Nicene and PostNicene Fathers, vol. 9.

19 Albert Currier, Nine Great Preachers (Boston: Pllgrim Press, 1912) 52 .

${ }^{20}$ Chrysostom, The Nicene and Post-Nicene Fathers.

21 Ammianus Marcellinus, The Surviving Books of the History of Ammianus Marcellinus, translated by John C. Rolfe in Ammianus Marcellinus, 3 vols. (Cambridge, Massachusetts: Harvard University Press, 1935).

22 Zosimus, Historia Nova, translated by James Buchanan and Harold T Davis (Texas: Trinity University Press, 1967).

23 Libanius, Selected orations, translated by A.F. Norman in Libanius: Selected Vorks, (Cambridge, Massachusetts: Harvard University Press, 1977). 
24 Sozomen, Ecclesiastical History, translated by A.Z. Zenos in The Nicene and Post-Nicene Fathers, 14 vols. (New York: Christian Literature Company, 18901 vol. 2.

25 palladius, Dialogue on the Life of st, John chrysostom, translated by Robert T. Meyer in Ancient Christlan Vriters 46 vols. (New York: Newman Press, 1985) vol. 45.

26 Socrates Scholasticus, Ecclesiastical History, translated by A.C. Zenos in The Nicene and Post-Nicene Fathers, 14 vols. (New York: Christian Literature Company, 1890) vol. 2 .

27 sozomen, Ecclesiastical History.

28 Chrysostomus Baur, John Chrysostom and His Time, 2 vols. (Westminster, Maryland: Newman Press, 1959)

29 Donald Attwater, st John Chrysostom: Pastor and Preacher (London: Harvill press, 1959).

30 T.E. Ameringer, "The stylistic Influence of the second Sophistic on the Panegyrical Sermons of st. John Chrysostom," diss., Catholic University, 1921.

31 J.A. Sawhill, "The Use of Athletic Metaphors in the Biblical Homllies of st. John Chrysostom," diss., Princeton University, 1928.

32 Mary Albania Burns, Saint John Chrysostom's Homilies on The statues (Washington D.C.: Cathollc Unlversity, 1930).

33 Robert L. Wilken, John Chrysostom and the Jews (Berkeley: University of Callfornla Press, 1983).

34 Charles Sears Baldwin, Mecleval Rhetoric and Poetic (Gloucester, Massachusetts: Peter Smith, 1959). 
35 George Kennedy, Greek Rhetoric Under Christian Emperors (New Jersey: Princeton University Press, 1983).

36 Andrews, The Practice of Rhetorical Criticism.

37 Thonnsen, et al., speech Criticism.

38 Bormann, The Force of Pantasy. 
CHAPTER II

JOHN CHRYSOSTOM: THE SPEAKER

INTRODUCTION "One man inflamed with zeal is sufficient to reform a whole
community."

This statement was delivered by John to the troubled citizens of Antioch in A.D. 387. In one important sense it provided an approprlate epitaph for John' life and rhetoric. One might legltimately question aspects of John's rhetorical vision and the reformation he so desperately sought. One could not, however, fault this prlest for his lack of personal or rhetorical zeal. It was that sense of Imperative and enthuslasm that set John apart from the secular rhetoricians of his day whose focus was more on oratorical display than persuasive effect. The combination of his rhetorical skill and rellgious conviction produced an eloguence that deeply Impressed his supporters and agltated his critics.

The varied influences that gave shape and direction to John's natural gifts are traced in this biographical chapter. His home environment, early rhetorical training, and Initial vocational uncertainty, blended together with his religlous conversion, monastic experlence, and leadership role in the church provided the sklll and substance for the rhetorical vision that dominated his life. It was his compulsion to address the moral and splritual issues of his day 
that catapulted John to the peak of popularity. That same outspoken compulsion also brought him into direct conflict with the political and religious hlerarchy, a conflict which eventually led to his exile and death.

Secular and ecclesiastical historians, contemporary with John, provide limited information on his background and career. John's own biographical references, in certain of his writings, help to expand the account. The key events of his life roughly divide into five distinct perlods. They are presented as follows:

1) HIS EARLY YEARS (A.D. 344?-370)

2) HIS ASCETIC--MONASTIC YEARS $(370-381)$

3) HIS PUBLIC LIFE IN THE CHURCH OF ANTIOCH (381-398)

4) HIS LEADERSHIP AS BISHOP OF CONSTANTINOPLE (398-404)

5) HIS FINAL EXILE AND DEATH (404-407)

This chapter concludes with a brief critique of John's personal strengths and weaknesses based on his own self analys is and the comments of his contemporarles.

\section{HIS EARLY YEARS (A.D. 344?-370)}

\section{Chlldhood Influences}

John was born in the cosmopolitan city of antioch some time between A.D. 344 and $354 .^{2}$ According to socrates scholasticus he was "the son of Secundus and Anthusa, and scion of a noble family." John's father, secundus, was an offlcer in the syrian army who died whlle John was still a child. Baur concludes that secundus was probably a Roman, statloned in Antloch. He apparently left an 
inheritance sufficient to provide for his family as well as for the future education of his son.

Anthusa, widowed at the age of twenty, never remarrled but instead devoted her full energies to the nurture of John and his older sister. of pure Greek descent, she secured for her son the best classical Greek education Antioch had to offer. ${ }^{5}$ As a devout Christian she taught young John the moral and spiritual principles of the church. Although John did not publicly embrace the faith of his mother until some years later, he did adopt her moral convictions and would one day echo them in his own rhetoric.

John did not mention his family members by name in his sermons or writings. However, a number of tributes to his mother do surface in his writings which reflect her deep impact upon his character. He wrote that his pagan teacher, Llbanlus, was so impressed with her exemplary Ilfe that he exclaimed: "Bless me! What wonderful women there are among the Christians. ${ }^{6}$ John pointed to her as a supreme example of virtuous widowhood, pralsed even by the "heathen. ${ }^{7}$ He also provided some glimpses into hls chlldhood home by putting these words on the lips of Anthusa as she descrlbed the "iron furnace" of her widowhood:

For no words are adequate to describe the tempest-tossed condition of a young woman who, having but lately left her paternal home, and being inexperienced in business, is suddenly racked by an over-whelming sorrow, and compelled to support a load of care too great for her age and sex. For she has to correct the laziness of servants, and to be on the watch for their roguerles, to repel the designs of relations, to bear bravely the threats of those who collect the public taxes, and harshness in the imposition of rates...a boy fllls her with ten thousand alarms and many anxieties every day, to say nothing of the great expense which one is compelled to incur if she wishes to bring him up in a liberal way.... My foremost help was the 
grace from above; but it was no small consolation to me under those terrible trials to look continually on thy face and to preserve in thee a living image of him who had gone, an image indeed which was a falrly exact likeness.... I do everything to provide lelsure for thy journey through this life.... For couldst thou say that ten thousand loved thee, yet no one will afford thee the enjoyment of so much liberty, seeing there is no one who is equally anxious for thy welfare.

Having been born Into the well-educated upper class of Antloch, John was exposed to unique educational opportunities not avallable to a11. His mother's verbal and Einancial support were essential factors in his first steps toward rhetorical greatness.

\section{Bhetorical Education}

Concerning John's education, Socrates Scholasticus wrote: "he studied rhetoric under Libanius the sophist and phllosophy under Andragathius the phllosopher. ${ }^{9}$ Palladlus did not mention any of his teachers by name, but with disdain commented that: "when he was eighteen, a mere boy In years, he revolted against the sophists of word-mongering." (see page 25$)^{10}$ Nothing is known concerning the character or curriculum of Andragathius. In contrast, more material Is avallable about the career and personality of the sophist Libanius than any other Greek of antiquity. ${ }^{11}$ From that information, plus additional data concerning schooling in the fourth century, one can gain an understanding of the type of education John received.

John probably began his elementary training in the Greek language at the age of seven. Under the tutelage of the "grammarian," he learned to read and write. From there he progressed to a middle school where more ambitious students were taught such subjects as Greek literature, history, poetry, geometry and geography. John may 
have been fourteen or fifteen years of age when this phase of his instruction was completed. His final educational step was to enroll in the school of the noted rhetorician, Libanius. This course of study extended over about four years. The major focus of the curriculum was learning and mastering the art of oratory. Especiallygifted graduates looked forward to lucrative careers in law or politics. 12

Libanius was born at Antioch in A.D. 314. His rhetorical skills were forged in Athens, the classical center of sophistry. He taught in Athens and Constantinople before returning to his home city. of his works fifty-one declamations, ninety-six progymnasmata, sixty-four orations, and approximately sixteen hundred letters have survived. Kennedy describes $\mathrm{hIm}$ as follows:

Much can be said in his favor: He writes excellent classical Greek, strongly influenced by Demosthenes, Isocrates, Plato, Aristides, and other classic writers. He represents the fading tradition of pagan classical culture of his age in its purest form. His long life, spanning the Fourth Century, was a time of many significant events, especially conflicts between pagans and Christians....His works are mines of political, social, economic, prosopographical, and intellectual Information.... But for all his 1 gुchievements he can be tiresome, repetitive, and unimaginative.

Libanlus was an outspoken critic of Christianity who frequently lamented over the growing influence of the Church. He blamed the Church for all that was wrong in the Empire. His hero was the pagan Emperor Jullan (361-363) who had temporarily restored the ancient gods and traditions to a position of honor. Libanius, grieving over the death of his saint, wrote this tribute in his funeral oration for Julian:

He [Julian] gathered together wisdom of every kind and displayed it--poetry, oratory, the various schools of philosophy... on the lips of every man of sense was the prayer that the lad should 
become the ruler of the empire, that an end be put to the ruin of civilization, and that there be put in chajge of the troubled world one who knew how to cure such ills.

Because they afforded the best educational opportunities of the day, it was not unusual for christian parents to send their children to secular instructors like Libanius. John learned the art of rhetoric from his teacher, but was apparently never enamored with his philosophy of l1fe.

Under Libanius, John was exposed to the type of rhetoric characteristic of the Second Sophistic Period. This renaissance of Greek rhetorical training lacked the depth and intensity of the classlcal period. In discussing the rhetorical schools of John's day Baldwin writes:

For sophistic is the historic demonstration of what oratory becomes when it is removed from urgency of subject matter. Seeking some inspiration for public occasions, it revives over and over again a dead past. Thus becoming conventionalized in method, It turns from cogency of movement to the cultivation of style. Cogency presupposes a message. It is intellectual ordering for persuasion, the means toward making men believe and act. Style, no longer controlled by such urgencles of subject, tends toward decoration and virtuosity. Sophistic practically reduces rhetoric to style....style and delivery, becoming the main reliance, are elaborated info a systematic technique to a degree almost incredible today.

As a preacher, John did not refraln from utilizing the tools of oratory he had learned from Libanius. However, in Christlanity he found the "urgency" that was missing in the rhetoric of his teacher. For John, Burns writes, "ornate and figurative language was a means to obtain a very serious and practical end." 16 In Christian preaching the ancient skills of public speaking found a new motive.

John occaslonally drew examples from his classical background, usually to make a negative comparison. For example he wrote: 
The unskilled person in men's estimation is not only one who is unpracticed in the tricks of profane oratory, but the man who is incapable of contending for the defense of the right faith, and they are right. But st. Paul did not say that he was unskilled in both these respects, but in one only; and in support of this he makes a careful distinction, saying that he was "rude in speech, but not in knowledge." Now were I to insist upon the polish of Isocrates the welght of Demosthenes, the dignity of Thucydides, and the sublimity of Plato, in any one bishop, st. Paul would be strong evidence against me. But I pass by all such matters and the elaborate ornaments of profane oratory; yea let a man's diction be poor and his composition simple and unadorned, but let him not be unskilled in the knowledge and accurate statement of doctrine; nor in order to screen his own sloth, deprive that holy appstle of the greatest of his gifts, and the sum of his praises.

John acquired from his secular professor a love for the Greek language and the necessary skills for a career in rhetoric. The time spent with Libanius provided a critical chapter in Chrysostom's rhetorical pilgrimage. But it was not the final chapter.

Vocational Uncertalnty

Following the completion of hls studies with Libanlus, John wavered regarding his future career cholce. Apparently it was assumed by those who had heard his early attempts at persuasive speech that he would put his eloquence to work in the legal profession or imperlal service. Jones suggests that John was prepared to enter a branch of the government responsible for writing official edicts. ${ }^{18}$ The acceptance of such an important position would have enhanced his own personal reputation and improved the social standing of his family. Concerning this decision Socrates wrote: "Being on the point of entering the practice of civil law, and reflecting on the restless and unfust course of those who devote themselves to the practice of the forensic courts, he was turned to the more tranqull mode of 11 fe." 19 
John's friend, Basil, who had been a fellow student in the school of Libanius, urged him to pursue "the blessed life of monks, and the true philosophy." 20 John was interested, but hesitant to pull away from the pleasures of soclety. John described his Inner tension:

Our balance was no longer even, but his scale mounted high, while $I$, still entangled in the lusts of this world, dragged mine down and kept it low, weighing it with those fancies in which youths are apt to indulge.... For it was impossible for a man who attended the law-courts, and was in a flutter of excitement about the pleasures of the stage, to be often in the company of one whi, was nalled to his books, and never set foot in the market place.

John finally resolved to leave behind the opportunities of a secular profession. Nearly twenty years passed before he embraced a new rhetorical opportunity as a priest in Antioch. Those years of public silence were formative years of religious training which impacted his rhetorical vision in ways vastly different from the training he had received from Libanius.

\section{Religious Conversion}

The example of his mother, his study of the scriptures, his acquaintance with Bishop Meletius of Antioch, and the impact of his friendship with Basil were all important factors in John's decision to turn to the Church. According to Palladius, Bishop Meletius took special Interest in John. He wrote: "impressed by the beauty of his character he had him almost constantly near him. He observed him with prophetic eye as it were, and he could envisage the young man's brilliant future." 22 John was baptized into the faith and continued to study under the care of the bishop for a perlod of three years. 
Following this time of instruction he was appointed reader, a position which involved John in calling the congregation to prayer and reading the scripture lesson. ${ }^{23}$

John gave his full attention to his new responsibilities. He also convinced his former classmates under Libanius, Theodore and Maximus, to leave their legal careers, "a professlon whose primary obfect was gain, to embrace a 11 fe of greater simplicity. ${ }^{21}$

wilken suggests that another factor may have also played a part in John's determination to turn from a legal career to a religious one. By the end of the fourth century the Church was able to offer vocational opportunities for the educated upper class that rivaled those in the secular arena. Influential eccleslastical offices were open only to those who had received a classical education. Being a member of the clergy often provided financial security and social status. Wilken writes:

In casting his lot with the Church, John turned his back on neither his social class nor his education. His family and friends all belonged to the world from which the hlgher clergy were drawn.... In choosing to join the Church, John was selecting a socially acceptable career with as much, if not greater, potentlal for success as law or the civil service.... In an eccleslastical career his rhetorlcal education would find ample opportunity for expression in preaching and writing.... In deciding to be baptized and to study the Christian Scriptures, John made a career cholce that was, if not coquentional, at least not unusual, and one that had its own rewards.

Throughout his religious career, John was very austere in his life style and he was an outspoken critic of the financial abuses of his fellow clergy. In the light of John's personal piety and stormy relations with the ecclesiastical hiearchy, one might question Wilken's explanation for why John chose the Church. It is impossible 
to accurately discern John's motives over the centurles. However, wilken's theory balances the overly simplistic explanations of the church historians. The "truth" probably lies somewhere between the two extremes.

John's rhetorical vision was given birth and nurtured by the various factors surveyed in this section. Before he preached his first homily another set of experiences was added. The next phase in John's preparation as a speaker was spent as a monk, in solltude and self-denial.

\section{HIS ASCETIC--MONASTIC QUEST $(370-381)$}

John's first desire after baptism was to retreat from society, flee to the desert, and assume the role of a monk. His mother's tearful intervention persuaded him to postpone his plans for some years. John remembered her arguments and slightly embellished them when he wrote:

I ask only one favor from you: do not make me a widow a second time; wait at least $t 111$ I die. Perhaps I shall soon leave this world. When you have buried me and jolned my ashes with those of your father, nothing will then prevent you from returning into monastic life. But as long as I breathe, support me by your presence, and do not draw down upon you the wrath of God by bringing such evils upon me who have given you no offense.?

Convinced by her appeals, John stayed and turned his home into a monastic study. According to schaff, John "practiced a rigid asceticism. He ate little and seldom, slept on the bare floor, and kept almost unbroken silence to prevent a relapse into the habit of slander."27 John's preoccupation with the "sins" of the tongue would surface repeatedly during his rhetorical career.

Together with his frlends John studied under the guidance of the 
ascetic philosophers, Carterius and Diodorus. Diodorus taught John to interpret the scriptures literally, rather than employing the allegorical method that had been proposed by orlgen and was used in Alexandria. ${ }^{28}$ This method became synonymous with the city of Antioch and was reflected in John's preaching.

John's earllest treatise was written to one of his friends, Theodore, to persuade him not to leave the ascetic life and marry. In the letter he employed a wide range of emotional appeals, arguments, warnings, and even harsh reproaches in an attempt to convince Theodore that it would be a terrible sin to forsake his vows and marry. For example, John wrote: "it is not the overthrow of a city which I mourn, nor the captivity of wicked men, but the desolation of a sacred soul, the destruction and effacement of a christ-bearing temple." 29 such words mirrored John's devotion to the ascetic principles of celibacy while also casting a little blame toward the woman for arousing such passions in a man. One of the reasons John wanted to escape the city was to remove himself from the temptations and lusts he felt lurked around every corner. His appeal to Theodore was successful and his friend reaffirmed his monastic pledges.

During this perlod of his life John purposely escaped appointment to the position of bishop. Convinced that he lacked the qualifications, he devised a scheme whereby he tricked his friend, Basil, into accepting the position, while he hinself avoided the appointment. In a letter to his friend, John defended his dishonesty with an "end justifies the means" type of argument. He wrote: "For great is the value of deceit, provided it be not introduced with a 
mischievous intention. In fact action of this kind ought not to be called deceit, but rather a kind of good management, cleverness and sk111." ${ }^{30}$ such reasoning, reminiscent of the logic of ouintillan, was characteristic of the ethical thinking of the fourth century.

Following the death of his mother, John left the city for the solitude of the mountains. Of his experiences in the wllderness Palladius wrote:

There he met up with an old man, syrus, who exercised great self-disclpline, and John strove earnestly to imitate his austere lifestyle. He spent four years battling it out with the crags of voluptuousness.... He retlred to a cave all alone, eager to dwell in obscurity.... He never relaxed for a two-year period, not in the days nor at night, and his gastric organs became lifeless and the proper functions of the kidneys were impaired by the cold. Since he could no longer take care of himself alone, he went back once more to the haven of the church. And this is a proof of the Savior's providence that he was taken away from the ascetic life by his sickness brought on by such strict habiths, forcing him to leave his caves for the benefit of the Church.

It is difficult to understand the type of monastic fanaticism that existed in the fourth century and so dominated the $11 \mathrm{fe}$ of John. For most Christians in the churches these hermits represented the ultimate in devotion to Christ. In addition to his lessons learned in solitude, John greatly enhanced his credibility in the minds of his listeners by having battled evil in the wilderness. Throughout his public career John continued to follow an ascetic life style. He frequently expressed his admiration for those who had chosen the way of monasticism above a public career in the Church and was convinced that: "the hermit makes progress in virtue more easily than he who is charged with the care of souls." 32 
HIS PUBLIC LIFE IN THE CHURCH OF ANTIOCH (381-398)

Bishop Meletius, who had previously admired John's rhetorical gifts, ordalned him to the position of deacon following John's return to Antloch. 33 John's ministry, in this capacity, acquainted him firsthand with the practical daily needs and pressures of the citizens of Antioch, especially the poor and the sick. This experience influenced him deeply. As a result, throughout his later years as priest and preacher, he often developed themes dealing with social injustice and the plight of the poor.

John's popularity spread. In the words of Palladius: "He had already become famous for his teaching and the people were sweetened from the bitterness of life when they met up with him. ${ }^{34}$ Having served flve years as a deacon he was ordained to the priesthood, in 386, by Antioch's new blshop, Flavian.

John preached his first sermon on the occasion of his ordination to the priesthood. It was filled with the ornate stylistic touches of sophistry he had learned from Libanius. The content of his sermon consisted of a humble confession of his own sense of unworthiness along with exaggerated praise for his tutors in the faith, Meletius and Flavian. 35

John spent the next twelve years at Antioch, teaching and preaching. His eloguent style was tempered by practical, down-toearth, challenges to the members of his congregation. Many in his audiences had only nominally embraced Christianity and their spiritual indifference soon became a target for his pulpit rhetoric. sunday after Sunday, and more frequently during Lent, John addressed his 
congregation on the duties and responsibilities of being Christian in the environment of Antioch. He also railed against the theatre, circus, and charlot-racing as examples of immoral behavior. His audiences were so packed together that he occasionally had to warn his hearers about the danger of pickpockets. 36

His twenty-one homilies, on The statues, were delivered only about a year after his ordination. John's decisive rhetorical response to the political and social crisis in Antioch greatly enhanced his reputation. The characteristics of his crisis rhetoric are presented later in this thesis.

Sozomen described John's effectiveness during these years in Antioch with these words:

John attracted the admiration of the people; while he strenuously convicted sinners even in the churches, and antagonized with boldness all acts of injustice, as if they had been perpetrated against himself. The boldness pleased the people, but grieved the wealthy and the powerful, who were guilty of most of the vices which he denounced.

HIS LEADERSHIP AS BISHOP OF CONSTANTINOPLE (398-403)

In 398, Nectarius, Bishop of Constantinople died. Eutropius, who exercised conslderable influence over the young and weak Emperor Arcadius, proposed John for the high office. He was aware of John's reputation from his visits to Antioch on officlal business. He persuaded Arcadius to write a letter to the governor of antioch summoning John to the capital city of Constantinople. 38

Theophilus, Bishop of Alexandria, opposed John's ordination. According to sozomen, Theophilus wanted to place his own candidate in the position. 39 Palladius attributed the opposition of Theophilus to 
his observation of John's character Including his "blameless outspoken language." 40 Under pressure from Eutropius he reluctantly agreed to consecrate John as Bishop. His strong opposition to John resurfaced later and was a significant factor in John's exile.

At first, John, by his eloquent sermons, galned the admiration not only of the congregation but of the Emperor Arcadius and hls wife Eudoxia. Secure in his authority he turned his attention to the reformation of a variety of abuses. In the words of Sozomen:

He was naturally disposed to reprehend the misconduct of others, and to antagonlze righteously those who acted unjustly; and he gave way to these characteristics still more in the episcopate; for his nature, having attained power, led his tongue $\ell_{1}$ to reproof, and nerved his wrath more readily against the enemy.

John soon came into conflict with both the clergy and the aristocracy. HIs rhetorical attacks were directed agalnst a variety of groups, concerns, and individuals: ${ }^{42}$

The clergy: He denounced members of the clergy for Immoral behavior. He condemned the practice of priests and women living together as brother and sister saying "the brothel-keeper was a better man. 43

The lalty: John spoke strongly agalnst injustice, avarice, Intemperance, flattery, gluttony, and lying.

The Church/finances: He checked into the financial practices of the Church and stopped what he thought was unnecessary and extravagant spending. He redirected the monies to the hospital.

Vidows: Investigating the order of widows, John criticized the sensuallty of some, advised them to fast, and demanded they display greater modesty. 
The rich: John repeatedly leveled his rhetoric against those who trusted in uncertain riches.

The Empress Eudoxia: In one of his homilies, John insulted Eudoxia by comparing her to the wicked old Testament character, Jezebel.

Bishop Theophilus, aided by Eudoxia and the disenchanted clergy, seized upon the opportunity to remove John from the office of bishop by accusing him of a variety of crimes and indiscretions. Some of the charges, such as immorality and treason, seemed to have no substance. other indictments were supported by greater evidence as stated by Young:

Most of the charges were comparatively trivial, though they added up to a severe treatment of his clergy, misuse of church property, an unfortunately sarcastic, almost libellous, tongue toward those who expected respect, and a refusal to practice the traditions of hospitality.

Refusing to defend himself, John was sentenced to exile, escorted to the harbor and put on a ship. The secular historian zosimus recorded the event:

When a trial was proposed, John, realizing that his case would be processed to a vote not at all equitably, left Constantinople of his own accord. The people were quite upset about this (for the man $45^{\text {was }}$ clever at demagogueryi and the city was full of tumult.

John's supporters reacted vlolently and stormed the palace demanding the return of their bishop. This was followed by "a calamity in the royal bedroom, ${ }^{46}$ possibly an earthquake, which was percelved by Eudoxia as a divine omen of disfavor. A few days later John was summoned back to the city.

His triumph was short-lived. Two months later the 
reconclliation between Eudoxla and John was shattered when John spoke out against the dedication of her silver statue, erected on the forum In front of the church. Eudoxia moved to convene another council to try John. Rather than back down, John angered her even more by openly denouncing her from the pulpit. According to Sozomen:

It was at this period that he pronounced the memorable discourse commencing with the words, "Herodias is again enraged; again she dances; again she seeks to have the head of John in a

Eudoxia was obviously not pleased with John's comparison of her with the Bible character who had had John the Baptist beheaded. Together again with Theophilus, she took action, persuading her husband to issue an order removing John from leadershlp. This time he refused to leave the church, Instead he continued to preach until taken prisoner by force.

John was sent into final exile by edict of Arcadius on June 5, 404. Zosimus reported that John's followers set fire to the church in protest of John's banishment. The fire spread and caused considerable damage, including the destruction of the Senate House. ${ }^{48}$ Palladius interpreted the events from a very different perspective. He saw the fire as evidence of divine displeasure concerning the treatment of John. ${ }^{49}$

In the west, Pope Innocent sought to intervene by calling for a church council Investlgation into the whole affair. He was unsuccessful. John expressed his reaction to his exile in a letter to Blshop Cyr lacus:

Then I was driven from the city, I felt no anxiety, but said to myself: If the empress wishes to banish me, let her do so; 'the 
earth is the Lord's.' If she wants to have me sawn asunder, I have Isaiah for an example. If she wants me to be drowned in the ocean, I think of Jonah. If I am to be thrown in the fire, the three men in the furnace suffered the same. If cast before wild beasts, I remember Daniel in the 1 ion's den. If she wants me to be stoned, I have before me stephen, the first martyr. If she demands my head, let her do so: John the Baptist shines before me. Naked I came from my mother's womb, naked shall I leave this world. Paul reminds me, 'If I still pleased men, I would not be the servant of Christ.'

John's perlod of leadership in Constantinople was marked by considerable conflict. The ancient historlans viewed the events from different perspectives, pointing the finger of blame at various participants in the drama. Many of the positive aspects of John's reform initiatives were overshadowed by the intense power struggle that developed between John, Theophllus, and Eudoxia. In this struggle John's rhetorical behavior, rather than promoting peace, added fuel to the fires.

\section{EXILE AND DEATH (404-407)}

Following an initial perlod of very poor health, resulting from the hardships of his journey into exile, John recovered and through extensive correspondence with his friends and church leaders exerted a more powerful influence than he had in Constantinople. Some 242 of his letters have survived from these years he spent in exile. 51

Purther incensed by his power, even at a distance, Eudoxia banned all correspondence and ordered John transported to Pityus, a more severe location. John died at Comana, while enroute, September 14, 407.

In 438 , his body was returned and enshrined at Constantinople. The Emperor Theodosius II and his sister Pulcherla met the procession 
and according to willey they: "kneeled down before the coffin, and in the name of their guilty parents implored the forgiveness of heaven for the grlevous injustice done to John." 52

The story of John's life and rhetoric is a fascinating account of the interplay of critical events, intriguing personalities, eloquent and sometimes abusive rhetoric, power struggles, religious devotion, and unusual fanaticism. John's strong rhetorlc lifted him to the heights and plummeted him to the depths. He was a product of his times. He had an impact on history.

Before turning to an analys is of John's rhetorical context in the next chapter, this section concludes with a brief summary evaluation of John's personality taken from the ancient ecclesiastical and secular sources and John's own words.

\section{JOHN'S CHARACTER}

The historians who were John's contemporaries, and who chronicled the biographical details of his life, were divided in their assessment of the controversial priest. Their observations and critical comments are essential in gaining an accurate picture of John's character traits. The following selective evaluations seem most valuable for our study:

Zosimus (Secular Historian--Wrote about the mid-fifth century)

From his perspective John continually used his rhetorical abilities to "agitate" the people, "stirring up incidents inside the city." He accused John of demagoguery: appealing to the emotions and 
prejudices of his audiences. He called John a "clever" man who used his position destructively. ${ }^{53}$

Socrates Scholasticus (Ecclesiastical Historian--urote about the midEIfth century)

Socrates presented a more balanced portrait of John than did 2osimus. Affirming the rhetorical skill of John he also emphasized that his "liberty of speech... was offensive to very many." Socrates commended John for his zeal, his simplicity of lifestyle, his powerful teaching, his passion for justice, his indignation concerning falsehood, and his eloquent and persuasive sermons. He criticized the priest for his abusive language, "immoderate vehemence," and his severe sternness of character. He quoted one of John's friends as saying: "that in his youth he manifested a proneness to irritability." He also reported that although John was powerful before his audience he was often considered, by those who did not know him, to appear to be arrogant in private conversation. 54

Sozomen (Eccleslastical Historian--Urote about the mid-fifth century)

To Sozomen, John had "wonderful powers of eloquence and persuasion." John excited many to a life of virtue by both his words and the model of his "divine life." He wrote of John: "He produced convictions simllar to his own because he did not enforce them by rhetorical art and strength, but expounded the sacred books with truth and sincerity. ${ }^{55}$ Like socrates, he also pointed out John's tendency to allenate his audience with abusive rhetoric. He seemed to feel that this aspect of John's personality became more visible as his power and influence grew. 
Palladius (Dlalogue on the Llfe of John--Wrote about (08)

At the opposite end of the continuum from zosimus, Palladius wrote to defend the memory of his friend. His praise of John was excessive. For every criticism or charge leveled against John he had an explanation or reproof. He commented on the charge that John was too bold in his speech by answering that John was just following the pattern displayed by the great characters of the Bible who were not afraid to reprove sinners openly. 56

\section{John (Commenting on himself)}

The two passages below were selected to provide some insight into how John viewed himself and his world. These quotations reveal something of John's own "battle of the soul" in dealing with the expectations of his listeners and in living in a world filled with conflicting values.

Thus then must the priest behave towards those in his charge, as a father would behave to his very young chlldren; and as such are not disturbed either by their insults or their blows, or their lamentations, nor even if they laugh and rejoice with us, do we take account of it; so should we neither be puffed up by the promises of of these persons nor cast down at thelr censure, when it comes from them unseasonably. But this 5 ;s hard, my good frlend; and perhaps, methinks, even imposslble.

of vainglory, indeed, it is honors and applause; of pride, abundance of authority and power; of envy, the reputation of one's neighbors; of avarice... and the constant society of women; and other passions...all these things will sorely attack me if I come forth into the world, and will tear my soul to pieces.... For these reasons I keep to this cell, and am inaccessible, selfcontalned, and unsoclable.... Therefore I beseech thee, too, to plty rather than to censure one beset with such great difficulty.

These brlef comments and evaluatlons provide a little more flesh for the skeleton of the historical John. In order to analyze his 
rhetoric one must seek to understand John, for his enigmatic blend of strengths and weaknesses were reflected in his sermons and writings. John preferred the solitude of the wllderness to the pressures of the crowds. Thrust into the spotlight of public acclaim he was both successful and uncomfortable. His Inability to translate the tranquility of the hermitage to the pluralistic culture of Antioch frustrated the priest. At the same time the eloquence that could soothe the masses could also be employed to stir up prejudices and incite less than holy passions. John's critics saw the tension. John, also, volced the anxiety and inner conflict of a rhetorician caught in the web of mixed motives and "ungodly" feelings. These glimpses of the ambiguous character of John help to demythologize the ancient saint of the Church, making him both human and approachable. This blographical sketch of John has Identifled key elements in his family background, education, religious experience, and personal character. Having introduced the speaker, it is now approprlate to examine John's historical context and rhetorlcal imperatives. 


\section{CHAPTER II NOTES}

1

Chrysostom, on The statues, I.33.

2 For a discussion of John's date of birth see Chrysostomos Baur, John Chrysostom and His Time, vol I: 3 .

$$
3
$$

6 Chrysostom, viduam juniorem, as quoted in The Nicene and Post-Nicene Fathers, vol. $9: 5$.

7 Chrysostom, $9: 5$.

8 Chrysostom, on The Priesthood, in The Nicene and Post-Nicene

Eathers, vol. 9: I.5.

9 socrates, IV. 3.

10 Palladius, 5.1 .

11 Kennedy, 151.

12 Baur, I :11.

13 Kennedy, 151-152.

14 Libanius, selected orations XVIII.21.

15 Baldwin, 7.

16 Burns, 119.

17 Chrysostom, on The Priesthood IV.6.

18 A.H.M. Jones, "St. Juhn Chrysostom's Parentage and

Education," Haryard Theologlcal Revley 46 (1953): 171-173.

19 socrates, VI.3.

20 Chrysostom, on The Priestheod I. 3.

21 chrysostom, I. 4. 
22 Palladius, 5.1.

23 Palladius, 5.1.

24 Socrates, VI. 3.

25 wilken, 7.

26 Chrysostom, on The Priesthood I.5.

27 phillp schaff, 5.

28 sozomen, VIII.2.

29 Chrysostom, To Theodore, In The Nicene and Post-Nicene

Fathers, 9: I.1.

30 Chrysostom, on The Priesthood I.8.

31 Palladius, 5.2.

32 Chrysostom, on The Priesthood VI.8.

33 Palladius, 5.2.

34 Palladius, 5.2.

35 schaff, 10.

36 schaff, 11.

37 sozomen, VIII. 2 .

38 Palladius, 5.4.

39 sozomen, VIII.2.

40 Palladius, 5.5.

41 sozomen, VIII. 3

42 Palladius provides an expanded treatment of John's attempted reforms. See 5.6-10.

43 Palladius, 5.6 .

44 Frances Young, From Nicaea to Chalcedon (Philadelphia:

Fortress Press, 1983) 154. 
45 Zosimus, V.23.

46 Palladius, 9.1 .

47 Sozomen, VIII.20.

48 Zosimus, V.24.

49 Palladius, 10.6 .

50 Chrysostom, quoted by schaff in The Nicene and Post Nicene

Eathers, vol.9: 14 .

51 schaff, 15 .

52 John Willey, Chrysostom: The orator (Cincinnati: Jennings and Graham, 1906) 156.

53 zosimus, V.22, 23 .

54 socrates, VI.3-21.

55 sozomen, VIII. 2.

56 Palladius, 18.9.

57 Chrysostom, on The Priesthood V.4.

58 Chrysostom, on The Priesthood VI.12. 
CHAPTER II I

JOHN CHRYSOSTOM: HIS RHETORICAL IMPERATIVES

\section{INTRODUCTION}

In order to understand the unique elements of John's cris is rhetoric one must grapple with the historical milleu which shaped his world and influenced his preaching. This essential task of the rhetorical critic is accurately described by Andrews:

One of the first factors to be considered... is the events that made it possible or necessary for a speaker to address an audience at all. People speak in order to solve problems, to gain adherents, to rouse interest and sympathy, or to compel action because there is something going on in the world around them that is in need of modification or is threatened and must be defended.

The turbulent setting of the fourth century provided a slgnlflcant rhetorlcal climate for John. He spoke because he was convinced his church, city, and world were in serlous danger. In John's mind a radical transformation of society was desperately needed. The same events that motivated John to stand and speak also swelled the slze of his audience. His llsteners, gripped by uncertainty and fear regarding thelr futures, were eager to hear his proposed solutions to their dilemma. Speaker and audience were drawn together by circunstances that demanded a rhetorical response. The concept, "rhetorical imperatives, ${ }^{2}$ is used in this chapter in descrlbing those historical, political, social, and cultural circumstances of the fourth century which moved John to speak and 
motivated his audience to listen.

John's homilies, on The statues, were delivered in response to a specific crisis event in 387 A.D. The tax riot and the resulting turmoil in Antioch certainly provided an Immediate and urgent context for John's rhetoric. On the surface that would seem to be the obvious rhetorical imperative that prompted John to address the terrorstrlcken crowds. However, behind the scenes of that explosion of public sentiment a variety of powerful political, social, economic, and religious forces fermented in conflict. The secular historians, Ammianus Marcellinus and zosimus, documented those changes in the Roman Empire from a pagan perspective. In contrast, the eccleslastical sources, Socrates and sozomen, viewed the same interplay of events through the lens of their faith. This clash of forces was vividly represented in Antioch by the competing volces of the pagan rhetorician, Libanius, and his former student turned prlest, John Chrysostom. Both John and Libanius were compelled to speak because of the events of the crisis. However, the changing state of the Church and the Roman Emplre provided John with additional significant reasons to speak. Those changes were also reflected in the audience that entered John's church. In this chapter I examine John's historical context in detail in order to understand these rhetorical imperatives.

In reconstructing the occasion of John's homilies, on The Statues, it is essential to first examine the unfolding drama of events within the larger setting of the Roman Emplre from fust prior to John's birth until the eruption of the crisis in A.D. 387. With 
this historical foundation in place one can better understand the audience that filled John's church in Antioch. This analysis of John's rhetorical context focuses on the following concerns:

1) THE CHANGING ROMAN EMPIRE FROM CONSTANTINE TO THEODOSIUS

2) THE COSMOPOLITAN CITY OF ANTIOCH

3) THE CHURCH IN ANTIOCH

4) THE RIOT IN A.D. 387

THE CHANGING ROMAN EMPIRE FROM CONSTANTINE TO THEODOSIUS

\section{Constantine}

The reign of Constantine (A.D. 306-337) was a pivotal point in the history of the Roman Empire. Constantine introduced a number of new elements into the turbulent political climate that continued to stir animosity and generate problems long after his death. On october 28, 312, Constantine won a decisive battle over his rival, Maxentius, which gave him control of the western portion of the Empire. He believed that his victory was the direct result of the intervention of the Chrlstian God and from that time on he enthuslastically sought to establish and promote the new faith as the accepted religion of the Empire. However, he continued to use pagan symbols on his coins and retained the title of Pontifex Maximus, symbolizing his role as head of the imperial cult. In 323, approximately twenty-five years before John's birth, Constantine became the sole ruler of the Bmpire. Under his relgn Christianity was freed from the threat of persecution, given equal standing with other accepted religions of the Roman world, and brought under the protecting influence of the emperor. This marriage 
of church and state, within a religiously pluralistic empire, created a whole new set of concerns for the emperors who followed Constantine. This tension was clearly reflected in the history of zosimus $^{3}$, the comments of Eunapius ${ }^{4}$, and the flery rhetoric of Libanius. 5

The passion of Constantine to build a new Rome in the east also angered his critics. They felt that his extravagant memorial to himself was built at the expense of the common citizen who was already overburdened with high taxes. 6 The establishment of Constantinople further served to polarize the Empire into eastern and western segments. The increased imperial presence in the east also served to enhance the reputation and political significance of John's city of Antioch in Syria. During Constantine's relgn the Great Golden Church was built in Antioch. This beautiful ediflce was to be the setting of many of John's persuasive addresses to his fellow citizens.

Zosimus condemned Constantine on a number of accounts: 1) his division of the Empire into four prefects, 2) his withdrawal of troops from the frontier which "planted the first seeds of our present devastated state of affairs," and 3) his luxurious 11 festyle and unnecessary gifts which impoverished the cities. He concluded his evaluation of Constantine's life with the statement: "Having grieved the state in all these ways, Constantine died." 7 Although zosimus wrote with a definite ant1-Christian bias which colored his perceptions, he did put his finger on Constantine's reckless financial policles which continued to undermine the economic stability of the Empire following his death. 
The political and religious changes that Constantine introduced to the Empire dramatically influenced the unfolding history of the Church. The impact of Constantine's decislons was still being felt some fifty years after his death, providing John with the rellgious freedom to speak openly and authoritatively to his fellow Antiochenes.

At the death of Constantine, control of the Empire was divided between his three sons, a brother, and two nephews. Constantius was given control of the eastern part of the Empire. According to Zosimus, Constantius acted quickly, following in the footsteps of his impious father, by plotting the deaths of his uncle, cousins, and a few other possible rivals. ${ }^{9}$ outliving his two brothers, constantius eventually became the sole ruler of the Empire in 353.

\section{Constantius}

While Constantius was struggling with internal and external threats to his Empire, young John was probably beginning to learn Greek in an elementary school in Antioch. On the eastern frontier Constantius faced a number of enemies who periodically engaged $h 1 m$ in battle. Ammianus identifed the Isaurians, Persians, and Saracens as sources of continued Irritation to constantlus. The Isaurians were located in the mountains of Asia Minor. Their frequent raids and guerilla style of warfare were a thorn in the flesh of the Emperor. ${ }^{10}$ The Perslans, under the leadership of sapor, continued to be a primary threat in the east, particularly for the city of Antloch which served as a base for military operations against them. Future emperors also 
had to contend with this eastern foe. Roving Saracen warriors complicated the situation with thelr perlodic raids. ${ }^{11}$

Constantius also had to contend with problems in the west. In response to growing opposition on the frontier, Constantius appointed his cousin Julian as Caesar in 355, giving him charge of the forces fighting in Gaul. 12

Throughtout his years of imperial leadership, Constantius faced a series of potential usurpers to the throne. He was successful in counteracting the threats of all but his cousin Julian. He was moving against Julian when he died of a fever in $361 .{ }^{13}$

While John was growing up in Antioch, Constantius was playing a crucial role in the theological battles of the Christian Church. Debate over the nature of Christ's divinity, known as the Arian controversy, was dividing the Christian community. Taking a creedal position opposite that of his orthodox father, Constantius proclaimed himself an Arian. He instituted persecution against orthodox believers and sought to establish himself as head of an Arian state church. ${ }^{14}$ This dispute was still fragmenting the church in antioch when John began his public career as priest.

Ammianus observed that although Constantius made pretensions to learning, he was dull of mind and falled in rhetoric. The savage bloodbath at the beginning of his reign rivaled that of any of the emperors that preceded him. His constant suspicions resulted in the investigations of those he perceived as a threat to his power and he responded to real and imagined threats with severe and often unjust retribution. He met with loss in foreign wars but rejoiced in his 
success in civil conflicts. His financial policies were oppressive and hated by the citizens of the Empire. His superstitious approach to Christianity fueled controversy and overshadowed what Ammianus called "the plain and simple religion of the Christians." ${ }^{15}$ Following his death, the church was faced with a new challenge: the Emperor Julian.

Julian

Born in Constantinople in 331, Julian escaped the terrorism of his cousin Constantius. He received a thorough education in Hellenic culture and rhetoric, both in Constantinople and later in Athens. Libanius, in his funeral oration for his hero Julian, described how their relationship began:

He discovered a method whereby he could share in my oratory without perfuring himself. He got someone, at considerable expense, to convey to him my lectures each day. And here he proved the power of his genius in the highest degree, for with no personal association with me, he imitated my style better than any of my regular pupils. By this more obscure path he surpassed the brilliance of their approach in the fruitfulness of his labours, and this is surely the reason why, in the orations he afterwords composed, there is some affinity $b^{i t h}$ my own and he was thought to have been one of my students.

Their friendship was later personalized when the Emperor Julian took up residence in Antioch.

Through his neo-Platonist studies, Julian was converted to a mystical form of paganism. He kept his conversion a secret for ten years.

Zosimus credited the wife of Constantius for suggesting that Julian be appointed as Caesar and given charge of the troops in Gaul. He quoted her appeal as follows: "He's young and of artless 
character. His entire IIfe he has devoted to the pursuits of knowledge and thus is totally unfamiliar with practical affairs."17 It was her contention that if Julian succeeded it would only make her husband look like a wise administrator, and if he falled, Constantius would no longer have to worry about any threats from a remaining member of the imperial family of constantine.

Assuming his new command in Gaul, Julian immediately distinguished himself as a military leader by winning important victories and securing needed treaties. He was crowned Emperor, in open defiance of Constantius, by his Gallic legions at paris in $360 .^{18}$ After the death of Constantius, Jullan turned his attention to the east where the Persian threat continued. He lived in Antioch while preparing to launch his offenslve against the Persians. Julian died in 363 as a result of injuries sustained In battle. ${ }^{19}$ He was thirty-two years old.

As sole Emperor, Julian openly professed his secret paganism. Ammianus wrote:

When he saw that the time had come when he could do as he wished, he revealed the secrets of his heart and by plain and formal decrees ordered the temples to be opened, victims brought to the altars, and the worship of the gods restored.

Reversing the trend of his immediate predecessors, Julian promoted a new standard of rellgious tolerance. However, he made it lllegal for followers of the Christlan religion to teach rhetoric or literature and in some cases looked the other way when Christians were

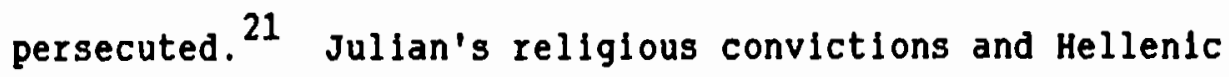
perspectives brought great joy to educated pagans like Libanius. 
Those within the Church, who had enjoyed special imperial favor since Constantine, now found themselves on the other side of the power struggle.

John was in his teens, maybe even a student of Libanius, when Julian resided in Antioch. He must have seen the revival of pagan sacrifices and have felt the impact of Julian's attempted renaissance of classical pagan culture. He may have heard his teacher lavish great praise on the young Emperor. John also must have witnessed the reaction of the Christian community in Antioch as they first faced an uncertain future and then rejoiced over the death of the apostate Emperor. John did not convert to Christianity until some years later. However, his memory of Jullan must have been vivid. John was faced with the possibility that another Julian might come to power and again overturn the security, freedom, and authority he possessed as a priest. Concerning Julian, John spoke:

For when Julian who surpassed all in impiety, ascended the imperial throne, and grasped the despotic sceptre, straightway he lifted up his hands against God... he promised that he would tear the nation of Galileans, out of the midst of the world; for thus he was wont to call us; and yet if he thought the names of the Christians an abomination, and Christianity itself to be full of much shame, for what reason did he not desire to put us to shame by that means, but with a strange name? Yea because he knew clearly, that to be called by what belongs to christ, is a great ornament..... on this account he set everything in motion, so as to strip us of this ornament, and put a stop to the preaching of 152 But this was impossible, 0 wretched and miserable man! 22

Jovian, a Christian, was elevated to the position of Bmperor following the sudden death of Jullan. After experiencing heavy losses Jovian managed to sign a peace treaty with the dangerous Persians. He reversed the policy of Jullan concerning the church. 
However, Jovian was unsuccessful in bringing theological peace to the Church. The death of Julian brought an end to the external threat to the Church, but the clergy renewed the battle within their own ranks. ${ }^{23}$ Jovian's relgn lasted a brief elght months before he died of either overeating or an accidental case of charcoal poisoning. ${ }^{24}$

\section{Valens}

Valens was appointed Emperor of the eastern provinces by his older brother, the western Emperor, Valentinian, in 364 . He spent a good portion of his reign stationed in Antioch. It was during these years that Chrysostom converted to Christianity, began his religious studies, and left the city to live as a monk. Valens provided for the building of a new forum in Antioch, which he named after himself. His construction generosity, however, was outweighed by his cruelty and he was strongly disliked by the citizens of Antloch. He was, wrote Ammlanus, "ready to gain advantage and profit at the expense of other's sufferings." 25 He was uneducated and untrained both in the art of war and liberal studies. ${ }^{26}$ A militant Arlan, like Constantius, he persecuted the orthodox Christians. His presence in Antloch only accentuated the intense religious conflict that already existed between various Christian clergy and their respective groups of followers.

After the death of his brother, Valentinian, Valens faced a host of invading tribes along the northern frontier of the Empire. Instead of waiting for help from Emperor Gratian in the west, Valens decided to engage the invaders in battle at Adrianople in 378 . The result was 
disastrous. Valens was killed and barely a third of his army escaped. Ammianus wrote that "the annals record no such massacre of a battle except at Cannae." 27

Following the devastating defeat of the Roman forces at Adrianople, Gratian appointed Theodosius as eastern Emperor in 379. Theodosius was Emperor when John began his rhetorical career from the pulpit of the Golden Church in Antioch.

\section{Theodosius}

A native from the town of Cauca in Spain, Theodosius had served as a frontier general in the west. His father played a crucial role in military campajgns in Britain, on the Rhine, and in Africa before being executed for political reasons in 375 . Theodosius retired from military service and returned to his home in spain following his father's execution. From there he was called to lead the government in the east. 28

Historical opinions on the leadership of Theodosius varied considerably. Zosimus viewed the ardent Christian Emperor with contempt and was extremely critical of his foreign policy, crediting his generals for winning the victorles that prevented the barbarlans from conquering the cities of the east. 29 Ecclesiastical historlans volced more admiration than criticism.

During the reign of Theodosius, imperial involvement in the affalrs of the Church increased. Leglslation was passed forbidding pagan rites and sacriflces. 30 The merging of Church and state, Inaugurated by the Emperor Constantine, was solidifled and expanded under Theodosius. Those in positions of religlous authority were able 
to influence political leaders and affect social, political, and economic issues as never before. John's rhetoric was set squarely in the context of this alliance of the sacred and the secular.

\section{Summary}

This historical synopsis of the eastern empire provides an essential foundation for understanding the rhetorical mood of antioch in 387. John's life and rhetoric were deeply imprinted with the contributions and controversies of these key political leaders. As we have seen, the late fourth century was marked by considerable insecurity and unrest. Barbarians were crossing the borders of the Empire, threatening the safety of the cities. Emperors faced rivals and would-be sovereigns who wished to seize power. Citizens were burdened with the weight of oppressive taxes that strained the social system. Advocates of the ancient religions and classical cultural values fought for survival as the influence of Christianity increased. The Church, torn by debate and theological controversy, struggled to find an elusive unity. The stage was set. The combination of these historical factors provided John with a strong incentive to speak out. The times seemed to demand a clear and forceful volce. John was prepared to answer the challenge of this rhetorical imperative. 
THE COSMOPOLITAN CITY OF ANTIOCH

Located on the orontes River in the northwestern corner of Syria, the city of Antloch stood alongside of Alexandria, Constantinople, and Rome in importance. The city was founded by Seleucus Nicator, one of Alexander the Great's generals, in 300 B.C.. The Greek colonists who first settled in the area utilized their classical city-planning skills in developing the city. The site they selected was eighteen miles from the Mediterranean Sea, a fertile, well-watered area of great natural beauty. By the time John walked on the paved streets, enjoying the shade of the covered walkways, the city was home for perhaps as many as 500,000 residents. $^{31}$

Ammianus Marcellinus, a native Antiochene, spoke of the city as the "fair crown of the orient." 32 The rhetorician Libanius wrote of his home: "I have heard people expressing envy for our city, because of its streams, Its breezes, its size and beauty, its inhabitants, the instruction in oratory...its willing students and able teachers." ${ }^{33}$ According to Ammianus, the brightness of the city lights made Antioch shine in the night with the same splendor it displayed in the sunlight. 34

Various emperors had made their contributions to the development of Antioch's beauty and architecture. On an 1sland, in the midst of the orontes, stood the imperial palace which had been bullt by Diocletian. Constantine added the Great Golden Church, the Basilica of Rufinus, the law courts, the Praetorlum, and a palace for the governor. As a young man, John must have looked on as the Emperor Valens provided a new Forum and great public baths. Nealthy cltizens, 
hoping to be remembered by future generations for their generosity, also contributed palaces, baths, porticoes, and promenades to Antioch's skyline. 35

The seaport of Seleucla, at the mouth of the Orontes River, gave Antioch a valuable harbor and an essential communication link to the rest of the Mediterranean. Located on a major trade route the city experfenced an influx of prosperity along with a blending of diverse cultures.

The unique cosmopolitan atmosphere of Antioch helped to produce a rich climate for John's rhetoric. This section briefly examines the social, economic, political, religious, and rhetorical elements of the Antiochene world of the fourth century.

\section{The Social Climate}

The city of Antioch had been established by its GraecoMacedonian founders to be a center of Hellenic culture In the eastern territory conquered by Alexander the Great. They brought a distinctive Greek mindset to the developing culture of Antloch by emphasizing the language, educational framework, and social customs of their homeland. Antloch was an Island of Greece transplanted in the soll of Syria. The Greek residents of John's time, with great pride, traced their ancestory back to the original Macedonian soldiers and Athenian settlers who had built the city centuries earlier. ${ }^{36}$ Therefore John's mother, Anthusa, who was of Greek descent made sure that her son shared in the educational blessings of the clty. An Indigenous Syrian community made their contribution to the 
city, spicing the Greek culture of the west with an eastern flavor. On the streets of Antioch, John saw representatives from a host of eastern cultures including Persians, Armenians, Arabians, Hindus and other peoples from beyond the frontier borders of the Roman Empire. ${ }^{37}$

A large and significant Jewish community also thrived in Antioch. They were the target of John's abusive rhetoric because of their strong influence on his congregation. The tendency of Christians to integrate Jewish practices into their lifestyles deeply incensed John. Wilken writes: "In reference to the Jews John uses the techniques of the psogos (invective) by employing half truths, innuendo, gullt by association, abusive and incendiary language, malacious comparisons, and In all excess and exaggeration." ${ }^{38}$ The international diversity of Antioch did not prevent the formation of deep undercurrents of prejudice and racial hatred.

The expansion of the Roman Empire introduced a fourth major ingredient to the social milieu of Antioch. The Romans respected the Greek culture of the city, but in making Antioch capital of the Roman province of syria, they quickly added their own cultural touch. The population of Antioch swelled with the presence of Roman troops, Roman businessmen, a Roman governor and his entourage, and frequently the emperor himself. Downey describes their impact on the city:

The emperors beginning with Augustus determined to transform the city physically and make it worthy of its new role. The main street was lined with the famous double colonnades; temples to the Roman gods were built; a statue of the she-wolf with Romulus and Remus, symbol of the origin of Rome, was set up. For the official state cult, a statue of the goddess Roma was provided. The theुgtre was enlarged, and aqueducts and basilicas were built. 
Christianity came to Antioch in the early days of the apostles. The city soon became a mission base for the spreading of the new religion. When John addressed the Christian community of Antioch in 387, nearly half of the residents professed to be Christian. The new faith added a final dynamic element to the social context of the great city.

The social climate of Antioch was enriched or degraded, depending on one's perspective, by a varlety of special events. Every four years the months of July and August were given over to the celebration of the Olympic Games. By the reign of Theodosius, the games in Antioch rivaled those of their namesake in Greece. 40 Tourists flocked to the city to enjoy the athletic contests, horse races, musical competions, speeches, and related events. Throughout the year the theatre and circus were alive with constant activity and charlot races stirred local passions. John frequently attacked such pleasures in his homilies. Antioch was well known in antiquity for its prevailing social vices. Gibbon described it vividly:

Fashion was the only law, pleasure the only pursuit...the arts of luxury were honored, the serlous and manly virtues were the subject of ridicule, and the contempt for female modesty and reverent age announced the universal corruption of the capital of the East. The love of spectacles was the taste, or rather the passion of the syrlans; a considerable share of her revenue was devoted to the public amusements, and the magnificence of the games, of the theatre, and the cirçus was considered as the happiness and as the glory of Antioch.

John was strongly influenced by every facet of the Antiochene culture. His rhetoric was delivered and heard in the midst of a very dynamic and diverse urban social setting. 
The Economic Climate

The area surrounding Antioch provided ample resources for a stable and prosperous economy. Downey illustrates this abundance: Orchards, fields, and forests provided an abundance of fruit and wheat; and there were vegetable gardens all about the city. Hunting was an important source of food, as well as a favorite sport. The forests provided timber for building, and stone could be quarried in the near-by mountains. One special source of enjoyment was the abundant supply of fish furnished by the Mediterranean, the Orontes, and the Lake of Antioch which lay in the plain north of the city.

The upper class of the city was composed of ex-officials, councillors, lawyers, veterans, prominent teachers, doctors, and clergy. ${ }^{43}$ Libanius modeled the life of the typical member of this economic strata. In addition to his role as a teacher, his energies were focused on managing his land holdings, engaging in business ventures, lending money, and supervising his numerous slaves. 44

Shopkeepers and craftsmen formed another class. Respected for the most part, they were nevertheless separated from the upper classes by a wide social gulf. ${ }^{45}$

At the bottom of the economic ladder were the peasants who farmed the land. Clustered in villages surrounding the metropolls of Antioch, they brought their goods to the city to trade.

Provided with rich natural resources, and enjoying the benefits of trade by land and water, Antioch's economy seemed stable. There were, however, some reoccuring problems. Libanius ldentifled a few when he wrote: "I would not consider her [Antloch] fortunate so much as the contrary, when I consider earthquakes and the ruin they have caused and invasions of the Persians with thelr pillaging, demolition and arson. ${ }^{46}$ These difficulties were compounded by periodic famines 
that ravaged the economy and forced large numbers of refugees into the city. The severe famines of 362 and $382-384$ were well remembered by the audiences that attended John's preaching. The heavy tax burden placed on the populace drained the economy further and fueled frustrations from the bottom to the top of the social ladder. 47

\section{The Political climate}

A succession of Roman Counts and governors were rhetorically attacked by Libanius for the ills they had brought upon the city. The material in his orations help to recreate the tensions of the times. His charges ranged from accusing the leadership of the region of cruelty and poor administration to indicting them for interfering with Antioch's cherished olympic Games. ${ }^{48}$ It is difficult to separate fact from rhetorlcal effect in Llbanius' orations. Apparently there were real problems in the administration of Justice in Antloch. Downey concludes: "Owing to a venal and inefficient judiciary, many men were committed to prison, but few left it. The judges often forgot or neglected the accused, and the senators did not dare interfere. ${ }^{49}$ Economic discontent magnifled the political unrest. In describing the tension, LIbanius recalled the rlot of 354 , when the enraged citizens of Antioch had lynched their governors and dragged their bodies around the city. 50 Antioch was a powder keg ready to explode.

\section{The Religious climate}

Antioch reflected a plurality of religious convictions and practices. The architecture and statues of the city witnessed to the powerful influence of classlcal Greek and Roman religlous thought. 
Great temples stood in honor of Jupiter, Mars, Apollo, Minerva, Ceres, and Fortuna. During the pagan revival of Jullan, John must have observed the slaughter of animals and seen the smoke rising from the burning sacrifices. Baur describes the scene as follows:

A multitude of small temples, sacred edifices and altars arose on all sides; these, in themselves alone, signified a whole school of Roman mythology, and reminded young John vividly of the recently vanished time of the bloody persecutions, the three-hundred-year struggle between paganism and Christianity; also of the bloody Caesars, whose statues stood in all the squares and ${ }_{1}$ street crossings, and looked down from all the monuments.

The forest grove of Daphne, with its temple to Apollo, was situated some five miles from the city. It was a favorite relaxation spot for the citizens of Antioch.

When John rose to preach in 387 , the devotees to these pagan deities were few in number compared to the swelling ranks of the Christians. However, John felt compelled to warn his audience of these temptations that surrounded them. He repeatedly attacked and denounced such groups as: pagans, Jews, heretics, upper class Christians, and apathetic fringe followers. He was not sure the Church might not be forced to again face an emperor like the pagan Julian. Wilken Interprets the mindset of John as he looked out on the religious diversity of Antioch and concludes:

John's ascetlc and unylelding plety, learned at the feet of the monks in the desert, only reinforced hls experiences as a young man growing up in antloch. Intemperance, obduracy, and impatience in the face of acculturated Christians set the tone of h1s early writings and preaching. As a young man, John felt himself beselged by foes, on the defensive. In his view, the Church had 5 but a fraglle hold on the alleglance of its followers. 
The Rhetorical climate

The rhetorician played an important role in the drama of the later Roman Empire. Nowhere was this more apparent than in the city of Antloch. For decades Libanius had given voice to the concerns and needs of the citizens of his cherished city. He had represented their case before local authorities and the imperial government. He became an important public figure and leaders listened to his counsel. Downey writes that, "his achievement was a tribute to the power which literary style and skill in oratory could command in those times. "53 The people of Antioch were accustomed to superb oratorical displays. The rhetorician, writes Wilken, was an "entertainer, a virtuoso, trained to dazzle the public no matter how grand the occasion or how trite his theme." 54

This fourth century fascination with rhetoric also influenced the developing pattern of Christian preaching. The imperial recognition of Christianity by Constantine drew masses into the Church who had little understanding of theology or spiritual ethics. Hubbell characterizes the situation as follows:

[These audiences]...demanded that the Christian priest should furnish them the same entertainment which they could receive from a Libanius or a Themistius. And the Christian priests, many of them trained under the best rhetoricians of the day, were not loath to accept the challenge. The contests in oratory in which itinerant sophists displayed their skill in encomia on Cynaegirus or Callimachus found a counterpart in the Christian Church when a succession of preachers used the same rhetorical tricks to glorify "The Forty Martyrs," and the audiences, crowding to hear thelr favorite preachers watghed for the "purple patches" and greeted them with applause. 
The pulpit became a new stage for performances of rhetorical art. According to wilken, "Christians began to idolize the Ir preachers the way pagans admired rhetors. ${ }^{56}$ John recognized this dilemma and complained: "a passion for oratory has taken hold of Christians." 57 Another great preacher of the period, Gregory of Nazianzus concluded in frustration, "It is orators they want, not priests." 58 preachers were critical of the sophistic tenor of the rhetorical skills they had learned in secular settings. However, they integrated many of those rhetorial techniques into their sermons. John was no exception. He condemned the cheering and applause of his audiences, but was unsuccessful in persuading them to stop. In the very middle of his rebuke the crowd was so impressed with his arguments that they applauded even more loudly than before. 59

The unique innovation of Christian preaching in the fourth century was not in technique but in rhetorical motivation. The Christian orator approached his task with an enthusiasm that had waned in the secular rhetorical arena. John definitely employed the stylistic tools of the sophist, but his purpose was altogether different. The priest directed his persuasive attacks against new religlous foes, rather than political enemies. His goal was to arouse church members from spiritual, rather than political, apathy.

In this section I have examined the historical setting of the city of Antioch in the later part of the fourth century. When John rose before his audience to speak, the mix of these social, economic, political, religious, and rhetorical elements affected both the speaker and the listener. These circumstances provided John with 
further reasons to communicate his message. Bullding on this contextual foundation, the next section focuses on the site where John delivered his homilies, the church in Antioch.

\section{THE CHURCH IN ANTIOCH}

Three subjects merlt discussion in reference to the rellglous organlzation that gave birth to John's rhetoric and whose members enthusiastically attended his services. These are: 1) the church's history, 2) the church's controversies, and 3) the church's buildings.

\section{History}

Christians in Antioch took great pride in their heritage as recorded in the Biblical book, The Acts of the Apostles.

Now those who had been scattered by the persecution...traveled as...far as Antioch, telling the message only to Jews. Some of them, however, men from Cyprus and Cyrene, went to Antioch and began to speak to Greeks also, telling them the good news about the Lord Jesus...a great number of people belleved and turned to the Lord.... The disciples were first called Christians at Antioch.

The Antiochene Christians revelled in the unique honor that came with being the birthplace of the name, Christian. Next to Jerusalem, the church in Antioch was the oldest Christian community. Peter, Paul, Mark, Luke and other early leaders had preached in the city. In Antioch the apostolic church had first penetrated the pagan Greek environment of the Empire. It had been from Antloch that the Apostle Paul first set out to evangelize Asia Minor and the rest of the Mediterranean world of the first century. St. Ignatius, one of their first bishops, had been taken to Rome and thrown to the lions. These 
memories became an essential part of their rhetorical vision. John frequently reminded his listeners of their valued past and its importance to their present situation. To John, no other city, not even Rome, had the credentials of Antloch. He said: "Our city is the head and mother of all that 1 ies in the East. $" 61$

\section{Controversy}

Theological conflict pervaded the Christian community in Antioch throughout the fourth century. The Arian debate over the divine nature of Christ was particularly divisive in the city. Also, the believers in Antioch seemed susceptible to splintering apart and following after certain more dynamic leaders. Arian emperors aggravated the situation by removing dissident bishops who professed the Nicene creed, and exiling them from the city. Sozomen described the turmoil in the church at Antioch about A.D. 360 when he wrote:

There were many aspirants to the see of Antioch; and as is frequently the case under such circumstances, contentions and seditions divided the clergy and the people of the church. Each party was anxious to commit the government of the church to a bishop of its own persuasion; for interminable disputes concerning doctrine were rampant among them, and they could not agree as to the mode of singing psalms; and, as has been stated, psalms were sung by eqch individual, in conformity with his own peculiar creed.

These controversies surfaced at varlous times during the fourth century, including the years that John pastored in Antioch. Bishop Plavian, who ordained John to the prlesthood, was a central figure in the conflict. According to socrates:

After the death of Paulinus, the people who had been under his superintendence refused to submit to the authority of Plavian, but caused Evagrius to be ordained bishop of their own pafty...those who disliked Flavian...held their assemblies apart. 
On some occasions the Christians in Antloch were divided into three camps. Refusing to meet together, they took control of various church buildings for their respective places of worship. At the time of the crisis in 387, things had settled down somewhat. In the words of Socrates: "the people of Antioch were in the course of a little while induced to acquiesce in the union secured. But the Arians of that city being ejected from the churches, were accustomed to hold their meetings in the suburbs." 64

John embraced the orthodox Nicene creed. In his preaching he focused on teaching the scriptures and exhorting Christians to careful living. He largely ignored the thorny doctrinal issues and refused to engage in the halr-splitting debate. Unity of the church community was an important theme in his rhetoric. The crisis of 387 overshadowed the internal conflicts of the church and gave John an opportunity to pull the ranks together.

\section{Buildings}

The main city of Antioch, and the surrounding suburbs, were filled with a varlety of chapels and martyrs' shrines. The major gatherings of worship were held, however, in the Great Golden Church or the old Apostolic Church. At the end of the fourth century an even larger church was under construction at the site of the martyrdoin of st. Babylas. Constantine had commissioned the building of the Golden Church in honor of Antioch's reputation as the place believers were first called Christians. The edifice was completed during the reign of Constantius. The church historian, Eusebius, described it in these words : 
He [Constantine] consecrated to the service of God a church of unparalleled size and beauty. The entire building was encompassed by an enclosure of great extent, within which the church itself rose to a vast elevation, being of an octagonal form, and surrounded on all sides by many chambers, courts, and upper and lower apartments; the whole richly adorned with a profusion 65 gold, brass, and other materials of the most costly kind.

The Great Church was located on the island in the center of the city, next to the imperial palace and the hippodrome. The golden dome of the church immediately captured the attention of visitors to the city. It was a dominant visible symbol to both Christians and pagans. It was the major stage for John's preaching.

At least the first three of his homilies, on The statues, were preached in the old Apostolic Church. Supposedly located on the site of the meeting place of the first Antiochene Christians, the Apostolic Church had a special significance for John. For him it was the "mother" church.

When it was time to speak, John stood on a small stand, located in the center of the church. There was no podium, reading desk or pulpit between John and his audience. People crowded around him. They were so close they could reach out and touch him. The congregation also stood throughout the entire homily which lasted about two hours. Wliken writes:

With nothing between himself and the audience, the sklllful preacher could move the emotions of his hears at wlll... The crowd was involved with cheering or booing as the case might be...they expected a top performance and the preache 66 was faced with constantly trying to top his last sermon.

It was in this setting that John preached his homilies concerning the crisis of 387 . The history of the Antlochane church, 
the problems of disunity, the splendor of the bulldings, and the urgency of the moment all imprinted their vivid marks on John's mind and soul and were reflected in his rhetorical response. Those in his audience were, also, deeply affected by these realities and were eager to hear an authoritative voice.

THB RIOT OF A.D. 387

The riot of $387^{67}$ was the immediate occasion for John's crisis rhetoric, on The statues. The cause of the riot and the unfolding sequence of events are of special importance to this study. The eyewitness accounts of John and Libanius provide considerable material about the circumstances of the riot.

\section{Cause}

The tax riot of 387 was not an isolated happening. Popular discontent was on the increase and was manifesting itself throughout the eastern part of the Empire. According to Libanius, "the governor's servants were scared that they (the mob) would break them down [the doors] and murder him, as has often occurred elsewhere on such occasions." ${ }^{68}$ Libanius mentioned disturbances in Alexandria and also referred to some outbreaks of support for Maximus, who was attempting to usurp control from Emperor Theodosius. Libanius identified one of the ringleaders of the Antioch rlot as having been involved earlier in a disturbance in Berytus. ${ }^{69}$ This evidence, writes Browning, "all points to a state of acute tension, which on the least excuse turned into open rebellion of large sections of the people against established authority. 70 
More is known of the crisis in Antioch than any of the other uprisings of the time. The riot was triggered by the contents of an imperial letter read before the court of Justice. The letter called for the establishment of an additional tax to be levied against the residents of Antioch. The purpose of the tax, according to Libanius, was as follows:

The emperor needed money for the maintenance of the empire, especially since his reign was approaching its tenth anniversary and his son's its fifth. Normally on such occasions 7 donative is handed by the rulers to their soldiery.

Whatever the specific nature of the tax, the immediate reaction of the city council was to protest. Browning suggests that their reaction may have resulted from the fact that the tax was directed primarily at the upper class of Antioch. ${ }^{72}$ John spoke of the tax affecting all of the inhabitants of Antioch. ${ }^{73}$ The tax may well have targeted the rich while also placing an additional burden on even the poorest of the city.

Sequence of Events $^{74}$

In the words of Libanlus, when the councll heard the contents of the letter they "lost control of themselves and behaved like lunatics." First they went to the governor and implored him with "dlsorderly and disobedient crles." Some "rowdles called upon thelr (Christian) god to plty them for reaching such a pitlable plight because of these decrees." The crowd went next to the home of Bishop Plavian to make their appeal to the religlous leader. Flavian could not be found. The lead was now taken by some "villainous fellows" who 
stirred up the rest of the populace outside the colonnade and "egged them on to participate in their own misconduct." Heading to the public bath they cut down the hanging lamps. The rioters then returned to the governor's residence. Libanius vividly descrlbed what transpired next:

They cast their eyes on the many portraits on the panels, and hurled at them first insults and then stones. They roared with laughter at those they shattered and lost their temper with those that stood up to this. Then they took it into their heads that bronze statues were of more account, and that misconduct towards them was more intolerable, and so they rushed upon them. They slung ropes around their necks, hauled them down and began to drag them along, some without chopping them up, others doing just that...they left the urchins to make sport with such revered objects, and themselves went with fire to attack the house of one who was guilty of no wrong-doing but yet was held to 75 e so by these people who refused to listen to the decrees.

Before the mob was able to ignite more bulldings the imperial archers arrived and the crowd fled in panic. The flre was extinguished and by midday the city was qulet. Soldiers arrested those who had participated in the arson and initial investigations began concerning the abuse of the statues. The governor immediately sent a messenger to the Emperor in Constantinople to inform him of what had taken place. Many of the upper class trled to flee the city of Antloch. The governor kept the council members sequestered with threats. The prisoners who appeared to be most guilty were quickly tried and condemned to death. Some were executed by the sword or fire. Others were thrown before wild animals and perished. ${ }^{76}$ John and Libanlus both blamed the riot on the actlvity of demons of differing origins. They also both indicted a group of strangers for inciting the mob to action. Browning identifies these 
"foreigners" as members of the theatre claque. He explores the changing influence of these claques in the fourth century and concludes:

What was in origin merely a claque, whose business it was to stimulate and maintain applause for theatrical performers, was now using its skill and its familiarity with the people to give the lead in political demonstrations in thg theatre, often expressing hostility to imperial officials.

He suggests that certain of the council may have recruited the help of the claque to organize a demonstration of the populace and to enlist the aid of the Bishop in the matter of the tax increase. The protest should have stopped when the Bishop was unavailable. Instead, the claque became a mouthpiece for the discontent of the average citizen and together with the mob they committed acts of open rebellion against the Emperor. ${ }^{78}$

The treasonous acts done, there was good reason to fear what might happen next. The church was full of multitudes seeking answers. In the light of the crisis John had a definite message to communicate.

\section{SUMMARY}

This chapter has explored the broad historlcal context for John's crisis rhetoric. The writer has sought to increasingly narrow that focus by also looking at John's city, his church, and the riot. In addition to the actual crisis, the combination of political, religlous, and social lssues, discussed in this chapter, provided John with a variety of important reasons to communicate. The Church's new sense of power and authority needed to be champloned in an Empire that 
now had a Christian emperor. Engaged in an ongoing struggle with paganism, the Church welcomed the preacher who would clearly identify and verbally attack the "enemy." Faced with its own internal factions, the Church needed strong charismatic speakers who could foster a sense of unity through their powerful rhetorical arguments. In examining the occasion for John's homilies, on The statues, these underlying rhetorical imperatives need to be recognized. John spoke, not only to calm a frightened audience, but to defend the truth as he saw it. John believed that the Christians of Antioch possessed the answer to the problem of the crisis. He felt he "must" call them to embrace their role in society. Keeping these rhetorical imperatives in mind, I now shift attention to John's response to the crisis. 
CHAPTER I I NOTES

1

Andrews, 18 .

2 Andrews, 18.

3 Zosimus, II.29.

4 Eunapius, The Lives of the Philosophers, translated by wilmer

C. Wright in Philostratus and Eunapius (Cambridge, Massachusetts:

Harvard University Press, 1921$) 379$.

5

Libanius, $X X X .37$.

6 Zosimus, II. 32 .

7 Zosimus, II.33-39.

8 A.H.M. Jones, The Later Roman Empire (Baltimore: Johns Hopkins University Press, 1986) 111.

9 Zosimus, II. 40 .

10 Ammianus Marcellinus, XIV. 2,1.

11 Ammianus, XIV. 4,1.

12 Ammianus, XV. 8, 1 .

13 Ammianus, XXI.15,5.

14 Glanville Downey, Antioch in the Age of Theodosius the Great

(Norman: University of Oklahoma Press, 1962) 49.

15 Ammianus, XXI .16,14-18.

16 Iibanius, Euneral oration over Julian, XVIII.15.

17 Zosimus, III.1.

18 Ammianus, $X X .4,1$.

19 Ammianus, XXV. 3, 23.

20 Ammianus, XXII. 5, 1.

21 Ammianus, XXII 10,7. 
22 Chrysostom, on The Holy Martyr, S. Babylas, IX:I.

23 Downey, 80.

24 Ammianus, XXV.10,13.

25 Ammianus, XXXI.14,5.

26 Ammianus, $X X X I .14,5$.

27 Ammianus, XXXI .13,19.

28 Zosimus, IV. 24.

29 Zosmius, IV. 26.

30 ZosImus, IV. 59.

31 Baur, I: 36 .

32 Ammianus, XXII. 9,14.

33 Libanius, XIX. 5.

34 Ammianus, XIV. 1,9.

35 Baur, I: 35 .

36 Downey, 12.

37 Baur, I: 38.

38 Wilken, 115.

39 Downey, 14.

40 Downey, 3.

41 Gibbon, Decline and Fall of the Roman Empire, as quoted in Schaff, p. 10 .

42 Downey, p. 11.

43 J.H.W.G. Liebeschuetz, Antioch (Oxford: Clarendon Press,

1972) 41 .

44 Liebeschutez, 44-47.

45 Lfebeschutez, 52. 
46 Libanius, XIX.6.

47 Libanius, XXVII.6.

48 Glanville Downey, Ancient Antioch (New Jersey: Princeton University Press, 1963) 186 .

49 Downey, Ancient Antioch 187.

50 Libanius, XIX.6.

51 Baur, I:29.

52 Wilken, 32 .

53 Downey, Ancient Antioch 194.

54 wilken, 95 .

55 Harry Hubbell, "Chrysostom and Rhetoric," Classical Philology

19 (July 1924): 263 .

56 Wilken, 95 .

57 Chrysostom, on The Priesthood V.8.

58 Gregory, "Oration XLIII.24," quoted by Hubbell in Classical

Philology 19 (July 1924): 263.

59 Chrysostom, To Those Who Had Not Attended The Assembly, IX:I.

60 Acts $11: 19-26$.

61 Chrysostom, on The statues III.1.

62 Sozomen, IV. 28 .

63 socrates, v.15.

64 socrates, v.15.

65 Eusebius, The Iife of constantine, translated by Arthur

Cushman MCGiffert in Nicene and Post-Nicene Fathers 2nd Serles, vol.

1 (Grand Rapids: Berdmans Publishing Company, 1952) III.50.

66 wiken, 105 
67 For a detalled account of the sedition see: Robert Browning, "The Riot of A.D. 387 in Antioch," Journal of Roman Studies XLII (1952) $13-20$.

68

69 Libanius, XIX.28.

70 Browning, 13 .

71 Libanius, XXII. 4.

72 Browning, 14.

73 Chrysostom, on The statues VIII. 4.

74 Libanius, XIX. 37.

75 Browning, 16.

76 Browning, 20 .

77 The most detailed account of the sedition is found in the Orations of Libanius. These selected quotes are taken from XXII.4-11. 78 Libanius, XXII. 7,8 . 
CHAPTER IV

JOHN CHRYSOSTOM: HIS RHETORICAL PURPOSES

\section{INTRODUCTION}

The riot in A.D. 387, discussed in detail in Chapter II, stunned the population of Antioch and left the citizens in a state of panic. Because of the slow nature of communications it took some weeks for the details of the insurrection to reach Emperor Theodosius in Constantinople. Further agonizing weeks of uncertainty passed before his response to the seditious acts was finally conveyed to the anxious citizens of Antloch. While the people waited for news, rumors of impending military action against the city were circulated, causing imaginations to run wild with fear. Many fled the city and sought refuge in the wilderness surrounding Antioch. Others stayed close to their homes, afraid to venture out on the streets because of the possiblity of arrest. Large numbers turned to the church for help in coping with the stress of the events. John preached throughout the weeks of the crisis. The majority of the twenty-one homllies, on The statues, were delivered during the days of greatest uncertainty and tension.

The weeks of the crisis paralleled the Christian season of Lent. This forty day period was a time of spiritual preparation that climaxed in the church's celebration of Christ's reputed resurrection 
from the dead. The Antiochene Christians traditionally observed Lent by fasting and acts of repentance. The painful reality of the emergency in the city, coupled with the sobering mood of Lent, provided John with an unusually powerful rhetorical opportunity. John described for his audience what he believed to be the positive ramifications of the entire crisis affair when he said:

The forum is indeed empty, but the church is filled; the former supplies material for melancholy, the latter is an occasion of joy and spiritual gladness! When therefore, beloved, you betake yourself to the forum, and the sight of the solitude calls forth a groan, fly back to thy Hother, and straightway she will console thee with the multitude of her offspring and will show thee the chorus of the Bretheren complete, and will drive away all thy despondency. For in the city we are as earnestly longing to see human beings, as those who inhabit the deserts; but when we take refuge in the church, we are straitened [sic] for room by the multitude. And as when the sea is in uproar, and rendered furlous by the violent tempest, fear compels all to fly for refuge from without into the harbour; so also now, the waves of the forum, and the tempest of the city, drives together every one from all sides into the church, and py the bond of love knits the members close to one another.

In the early weeks of the crisis John addressed his congregation on an almost dally basis. His homilies were based on a variety of Biblical texts. The priest's chosen topics both echoed and Interpreted the changing state of circumstances in Antioch. His rhetoric was not aimless but consistently purposive in focus. In this chapter, I examine ten selected homilies from John's series, on The

statues. Each homily is discussed in terms of its setting in the overall context of the crisis. John's rhetorical purposes, stated and implied, are ldentifled and analyzed. 
HOMILY I

\section{Setting}

John delivered the flrst homily of his Lenten series in the Apostolic Church about a week before the actual riot engulfed Antioch. One may deduce from the nature of his rhetoric that tensions were already brewing among the citizenry. A major portion of the homily dealt with the problem of suffering and John's vocabulary included frequent use of words like dangers, terrors, hardships, punishment, afflictions, and death. At the conclusion of his homily he made reference to a vague group of "blasphemers" whom he felt represented a threat to the welfare of the city. John urged his audience to action with the words:

Correct on my behalf the blasphemers of this city.... Do thou too then contend, even to the death, for the truth, and God will fight for thee! and make me not this cold reply. 'What matters it to me?'...This indeed I, for my part, engage with the strictest certainty, and pledge myself to you all, that if all you who are present will but choose to take in hand the safety of the inhabitants of this city, we shall speedily have it amended throughout.... One man inflamed with zeal is sufficient to reform a whole community.

It is impossible to draw a definite conclusion, but one has to wonder what effect such rhetoric had on John's audience. Did his words add fuel, or even spark, to what was already a tinderbox of emotion in the city? Could his persuasive appeals have helped to precipitate the very crisis he sought to prevent? His message certainly seemed to advocate the use of vlolence if the goal was, in his estimation, a worthy one. John continued:

And should you hear anyone in the public thoroughfare, or in the midst of the forum, blaspheming God; go up to him and 
rebuke him; and should it be necessary to inflict blows, spare not to do so. Smite him on the face; strike his mouth; sanctify thy hand with the blow....For if it be necessary to punish those who blaspheme an earthly king, much more s $\xi$ those who insult God. It is a common crime, a public injury.

To support his argument, John pointed to the defiant behavior of the Biblical character, John the Baptist, who boldly condemned the sinful acts of even a king. His appeal was as follows:

Truly, if I had said unto thee, punish and correct those kings or judges who transgressed the laws, would you not say that I was mad? But John fgrsooth acted thus. So that even this is not too much for us.

Could such phrases have been interpreted by John's listeners as a justification for revolting against the Emperor's seemingly unfust taxation demands? It appears to this writer that John's rhetoric might indeed have had this effect, providing the discontented with a spiritual rationale for their destructive acts of rebellion against the Emperor Theodosius. In reference to John's behavior some years later as bishop of Constantinople, the secular historian, Zosimus, accused John of using his rhetorical skill to incite the crowds in opposition to the authorities. The result, according to zosimus, was that John's followers rioted and burned down the church. 5 what may have happened in both contexts was that John's overzealous disciples, motivated by his fiery eloquence, went far beyond their teacher's rhetorical intentions. These comments are presented only as conjectures to suggest that a possible link might have existed between John's first homily and the riot that ensued a few days later. 


\section{Rurposes}

In the opening words of his first address, John employed a musical metaphor to describe the purposive tones of the scriptures. The carefully drawn word picture clearly reflects how he perceived the task of preaching and provides insight into his rhetorical purposes. John said:

Ye have heard the Apostolic volce, that trumpet from heaven, that spiritual lyre! For even as a trumpet sounding a fearful and warlike note, it both dismays the enemy, and arouses the dejected spirits on its own side, and filling them with great boldess, renders those who attend to it invincible against the devil! And again, as a lyre, that gently soothes with soul-captivating melody, it puts to slumber the disquietudes of perverse thoughts; and thus, with pleasure, instills into us much profit.

The words "dismay," "arouse," and "soothe" accurately convey the basic thrusts of John's rhetoric. His statements alternated between warmly passionate expressions of comfort and strongly assertive messages of judgmental exhortation. Concerning his inner motivations as a speaker John declared:

And this we would do, not for the love of praise, nor because we study to exhibit powers of oratory... but in order that we may stir up those hearers who are too listless, and may convince them of the greatness of the treasure of the holy scriptures; and that it is nelther safe, nor free from perll, to run through them hastily.

In addition to these general purposes John had another specific objective in mind as he delivered Homily I. A considerable portion of his address focused on the problem of human suffering and was his attempt to answer the question of why good people experience economic loss, personal sickness and injuries, tragic and unexplainable reversals, and other "evil" consequences. Using scriptural examples, 
John sought to encourage his congregation to quietly endure such hardships, recognizing that the difficulties were an inevitable result of their faithfulness to God. His argument was as follows:

Do thou also, when about to perform any duty to God, look forward to manifold dangers, manifold punishments, manifold deaths; and be not surprised, nor be disturbed, if such things happen.... For surely no one choosing to fight, expects to carry off the crown without wounds! And thou, therefore, who hast undertaken to wage a complete combat with the devil, 8 think not to pursue a life without danger, and full of luxury! ${ }^{8}$

It is also possible to discern a subtle, implied purpose in John's first homily. Before becoming a priest, John had spent a number of years as a monk, practicing a rigid self-denial that had left his body weak and sickly. As he spoke of the suffering of the Biblical character, Timothy, his audience must have heard veiled references to his own predicament. He interpreted Timothy's stomach troubles as being the result of rigid fasting practices and held him up to the audience as a prime example of spiritual devotion. It would have been hard for John's listeners to miss the obvious comparison of their emaciated priest with the Timothy of the scriptures. Just as Timothy was not delivered from his suffering, so their leader had to live with the scars of his plety. To John's congregation these scars were badges of honor won in spiritual battle. By drawing subtle attention to his infirmitles, via the example of Timothy, John was enhancing his own crediblilty and authority as a speaker. John went on to contrast apparent and real strength with the following assertion:

For as with those who possess well-regulated and sound constitutions, strength is of no avall, if the soul is abject, slothful, and stupld; so with those who are reduced to 
extreme weakness, no hurt arises from their infirmity, if the soul be noble and well awake.

The content of John's first homily took on special significance when, as a result of the sedition, the citizens of Antioch began to experience both physical and emotional suffering. Throughout the crisis he continued to sound the same two notes of comfort and challenge introduced in his opening message.

HOMILY II

\section{setting}

John's second homily was delivered on Saturday, seven days after the riot. John spent the intervening days in self-imposed silence as a symbolic declaration of his serious grief over the circumstances that had consumed Antioch. The anticipation of his audience must have been heightened to a fever pitch as they waited for him to finally speak to them. His first words were:

What shall I say, or what shall I speak of? The present season is one for tears, and not for words; for lamentation, not for discourse; for prayer, not for preaching. Such is the magnitude of the deeds daringly done.

John repeatedly emphasized the inappropriateness of rhetoric in such a moment, yet he continued to speak. He described the state of affairs in graphic detail, contrasting the peaceful past with the present moment of turmoil. John focused on the unique emotional nature of the crisis. The city was literally being held captive by fear. According to John:

Now our calamity has become an enigma; a flight without enemies; an expulsion of inhabitants without a battle, a captivity without a capture! We have not seen the fire of 
barbarians, nor beheld the face of enemies; and yet we experience the sufferings of captives.

Alluding to a recent earthquake, John characterized the paralyzing impact of the situation with these words:

Lately our city was shaken; but now the very souls of the inhabitants totter! Then the foundations of the houses shook, but now the very foundations of every heart quiver; and we

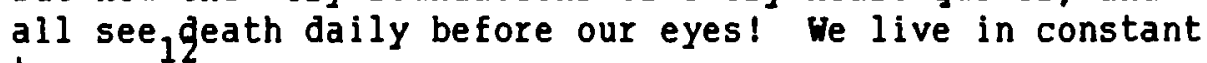
terror.

John took the Biblical lesson for the day: "Charge them that are rich in this world that they be not high-minded, " ${ }^{13}$ and amplified its meaning with 1llustrations drawn from the crisis. The marbled walls of the homes of Antioch's rich citizens were no defense against the threatened peril. Their money was useless in obtaining a pardon from the Emperor. According to John, all the gold of Antioch would be "utterly impotent" in appeasing the anger of God. ${ }^{14}$ The crisis provided John with ample materlal with whlch to adorn his persuasive appeals.

\section{Burposes}

In studying John's initial response to the calamity in Antioch, it is possible to discern four clear purposes in his rhetoric. His first priority was to place the crisis in a spiritual context. He clarified to his listeners what he saw to be the demonic and the divine counterparts in the historical drama of the riot. The devil had raged against the city of Antloch. But God had permltted the events to take place. In John's mind God's objective in allowing the tragedy was that "He may make us more sober-minded by the extremity of this tribulation." 15 
Secondly, John was qulck to $\mathrm{fix}$ blame on both his congregation and the instigators of the actual riot. He heaped shame on his listeners for failing to follow his command to seek out and correct the "blasphemers" who were troubling the city (See Homily I). His 'I told you so' argument went as follows:

I asked you to restrain those who are violent and insolent against God! I do not think that I then spoke these things of myself; but that God, foreseeing what was coming, injected these words into my mind; for if we had punished those who dared to do such things, that which has now happened would never have happened.... Bephold the crime was that of a few, but the blame comes on all!

John identified "certain strangers, men of mixed race--accursed and pernicious characters--hopeless of their own safety ${ }^{17}$ as the ones who perpetrated the treasonous acts against the statues.

John's third purpose was to encourage and comfort his audience. He directed their attention to the resources of God's love and their certain hope for the future. He concluded: "Let us not be cast down. Let us not lament, nor fear the difficulty of the times.... Let us beseech Him continually. 18

Finally, John again sought to mobilize his congregation to take action against the wicked men of the city. Chastizing them for their listlessness, he clearly identified what he expected them to do in response to his message:

Being chastened by our present calamity, let us now restrain the disorderly madness of these men. Let us shut up their mouths, even as we close up pestiferous fountains... and the evils which have taken hold of the city shall undoubtedly be stayed. The Church is not a theatre, that we should listen for amusement.... What need have I of these plaudits, these cheers and tumultuous signs of approval? The praise if seek, is that ye show forth all I have said in your works. 
The first two homilies, occuring on either side of the rlot, were inseparably linked together by John in his claim of prophetic insight: "These things I foretold, and they have now actually taken place. ${ }^{20}$ This must have deeply impressed his audience, causing them to listen even more carefully to their priest. John seized the opportunity, giving his interpretation of the events of the day and stressing his rhetorical agenda for the church at Antioch.

HOMILY III

\section{Setting}

John's third message was delivered on Sunday, the day after he preached Homily II. He communicated to his audience the most recent development in the affair of the statues. Bishop Flavian had left Antioch and was traveling to Constantinople to appeal to the Emperor for mercy because of the treasonous crimes that had been committed. John spent considerable time praising the Bishop's selfless act on behalf of the city, and rehearsed for his listeners the dialogue he imagined would take place between the aged Bishop and the angered Bmperor. It was the sunday before the commencement of Lent and John was eager to connect, in the minds of his listeners, the seriousness of the religious season with the seriousness of the crisis atmosphere in Antloch. He helghtened the audience's awareness of what was happening to those who had been selzed and charged in the matter. John painted a grim plcture of the helpless despair of family members witnessing the deaths of their loved ones: 
They were led away to the pit, without reprieve; armed soldiers conducting and guarding them on either side, lest anyone should carry off the criminals; whilst mothers also followed afar off, seeing their children beheaded, but not daring to bewall their calamity; for terror conquered grief, and fear overcame nature!

From John's words it is possible to discern that his audience was struggling not only with fear, but with questions regarding justice, the punishment of the innocent and the escape of the guilty.

\section{Purposes}

In addition to reaffirming some of the objectives previously stressed in his earlier homilies, John clearly and subtly presented some new concepts he hoped his audience would embrace. He focused his rhetoric on the issues of the Lenten fast, the triumph of ultimate justice, and the danger of greater calamities if the citizens of Antioch falled to change their pattern of living in the light of the present distress. John also wove into the fabric of his sermon a strong assertion concerning the authority of religious leaders in the Empire and a subtle negation of the role of women and Jews.

The proper observance of the Lenten fast was of major concern to John. He expended considerable rhetorical energy in emphasizing the value of virtuous fasting. For example, John preached:

When the fast makes its appearance...let us as soldiers burnish our weapons; and as husbandmen let us sharpen our sickle; and as sailors let us order our thoughts against the waves of extravagant desires; and as travelers let us set out on the journey tqwards heaven; and as wrestlers let us strip for the contest.

John was convinced that the issues of religion and the attainment of virtue were far more important than deliverance from the frightening 
circumstances of the crisis. ${ }^{23}$ He articulated a spiritual agenda for the days of Lent, extending the principle of fasting to include every facet of human communication and behavior. The mouth was to fast by avoiding both food and disgraceful speech and slander. The hands were to fast by being pure of thievery and greed. The feet were to fast by avoiding attendance at pagan events. The eyes were to observe Lent by ignoring the temptations of beauty and lust. Finally, the ears were to fast by refusing to listen to evil words and false reports. ${ }^{24}$

John repeatedly condemned the practice of slander, swearing, and the taking of oaths. It is interesting to speculate concerning his fixation on these communication topics. John was criticized by secular and ecclesiastical historians of his time for his own vicious tongue and a habit of slandering his opponents. ${ }^{25}$ Perhaps his preoccupation with these themes reflected something of his own internal struggle.

Matters of justice also demanded John's response. People were complaining that the guilty were escaping punishment while the innocent were being persecuted. John argued that divine justice guaranteed final equity. The innocent, experlencing present judgement, were paying for previous crimes for which they had falled to repent. Those who had seemingly escaped fustice had the present moment to repent or a greater chastisement would descend upon them. ${ }^{26}$ John warned his audience of the posslbility of greater divine retribution with the words:

May there be then speedily some favourable and propitious change! This certainly I foretell and testify, that although this cloud should pass away, and we yet remain in the same 
condition of listlessness, we shall again have to suffer much heavier evils than those we are now dreading; for I do not $5_{2} 7$ much fear the wrath of the Emperor, as your own listlessness.

John emphasized the growing power of the pulpit, and the political influence of the church in the context of the fourth century, by vividly describing the armaments of the priesthood in contrast with those of the Emperor:

He (Blshop Flavian) is also himself a ruler and a ruler of more dignity than the other IEmperor Theodosiusl. For the sacred laws take and place under his hands even the royal head. And when there is need of any good thing from above, the Bmperor is accustomed to fly to the priest; but not the priest to the Emperor. He too hath his breast-plate, that of righteousness. He too hath his girdle, that of truth, and sandals of much greater dignity, those of the gospel of peace. He too hath a sword, not of iron, but of the spirit; he too hath a crown resting on his head. This panoply is the more splendid. The weapons are grander, 28 he license of speech greater, and mightier the strength.

Such rhetoric reflected the changing times and reinforced John's own position of authority in the community. For a church fllled with those who could remember days of official government persecution under Emperor Julian, the new sense of power must have seemed like a divine validation of the hierarchy of Christianlty.

In contrast with this image of male religious dominance, John unfavorably characterized the role of women and Jews in the city. He used both of these groups as examples when illustrating moral or spiritual weakness and relished opportunities to contrast the power of Christianity with wat he felt to be the inadequacy of the Jewish faith. For example, if the old Testament Jewess, Esther, had been able to save her people from destruction, the Christians of Antioch could be certain that their holy Bishop would be successful in saving 
Antioch from ruin. ${ }^{29}$ It is possible to conclude that John's rhetoric served to further divide and polarize the community along social and religlous lines.

The introduction of these purposes further sharpened the focus of John's crisis rhetoric. The crisis, and surrounding controversy, provided a context for him to affirm his priorities for the church and the city.

\section{HOMILY V}

\section{Setting}

John delivered homilles II- $X$ on successive days. His fifth message was preached on Tuesday, two days after the sermon discussed above. With each passing day the mood of the citizens grew more ominous. The Impending wrath of the Emperor settled, like a dark cloud, over the city of Antioch. People debated whether to flee the city or remain behind to wait the unknown. Recognizing in his audience a spirit of depression and intense fear, John exhorted his congregation to stay in antioch and exhibit an attitude of patient endurance. He urged them to change their habits rather than their habitations. 30

\section{Purposes}

John's major rhetorical purpose in Homlly $\mathrm{V}$ centered on the fears of his listeners. Using Biblical characters as examples, he sought to redirect the emotions of his audience from the present crlsis to a greater spiritual drama. He articulated his premise with these words: 
Let us raise ourselves from the defection which oppresses us. For I have laid these histories before you, not that ye may applaud what is spoken, but that ye may imitate the virtue and patience of such noble men; that ye may learn from the very facts, that there is nothing of human ills to be dreadeg, save sin only...the true calamity consists of offending God.

Instead of being paralyzed by their fears, John wanted his congregation to demonstrate a contempt for death. Embarrassed by their fear of physical death, John proclaimed:

Is our doctrine, indeed a fable? If thou art a Christian, belleve in Christ; if thou believest in Christ, shew me thy faith by thy works. But how mayest thou shew this? By thy contempt of death: for in this we differ from the unbelievers. They may well 3 fear death; since they have no hope of a resurrection.

He preached on, describing what he called: "this childish terror of ours, if we fear death, but are not fearful of sin. ${ }^{33}$ The Christian "soldier" will never carry out his God-given tasks if he is terrified by earthly dangers. "In contrast the man who is bold and lofty minded "remains impregnable and unconquerable." 34 John repeated his theme again and again, using a varlety of arguments and persuasive appeals. He concluded with the challenge:

It is impossible to fly from the hands of God; whithersoever any one may roam, dragging his sin after him, he will have to undergo a thousand evils.... Let us not then provide for our safety by flight, but by a change of moral character. Is it for remaining in the city that God is angry with thee...that thou shoulgुgst fly? It is because thou has sinned, that He is ind ignant.

With each passing day of the crisis, John's call for spiritual reformation became more pronounced. 
HOMILY VI

\section{Setting}

The next day John again stood and addressed the troubled crowds. He was encouraged by what he perceived as a visible change of behavior among the citizens of Antioch and he felt there was cause to rejoice. Because of the crisis, people were more serious and diligent. Prayers and tears were replacing laughter and the singing of lustful tunes. In the place of drunkeness and profane language there was an attltude of quiet attentiveness. ${ }^{36}$ In John's words: "the city is now in all respects, like the pattern of a modest and virtuous woman... be thankful to God, that by the terror of a few days He hath put an end to such stupidity. ${ }^{37}$

There was another reason for optimism. John had received news that the messengers who had been dispatched by the governor with word of the riot had been delayed on their journey to the Emperor. To John this was a powerful omen of God's intervention on behalf of the city and a further cause for thanksgiving.

The sacred season of Lent, coupled with the strong religious sentiments of their Emperor, provided a third cause for renewed hope. John communicated a message of confidence: "This...will assuredly rescue us from the Emperor's wrath. " 38

\section{Purposes}

Buoyed up by the changing state of affairs, John continued to comfort his listeners. He descrlbed hls role with these words: 
As long as the sore of despondency remains, we will apply to it the medicine of consolation. For if in the case of bodily wounds, physicians do not give over their fomentations, until they perceive that the pain has subsided; much less ought this to be done in regard to the soul. Despondency is a sore of the soul; and we must foment it continually with soothing words.... The judges affright; the priests therefore must conşgle! The rulers threaten; therefore must the Church give comfort.

In addition to this basic intent, John urged the masses to show proper respect for their divinely ordained political leaders. God had armed the magistrates with authority for the good of all citizens. The recent riot provided a good illustration of this "truth." If the leaders and soldiers had not intervened, the mob would probably have destroyed the entire city. Without the structure of authority and the fear of punishment, John continued, "cities would fall on one another in unrestrained confusion, there being no one to repress, or repel, or persuade them to be peaceful. ${ }^{40}$

John concluded the homily by commanding his audlence to further reform their speech behavior by avoiding all oaths and swearing. Discussions concerning God's laws ought to replace profane talk in every context, including at home, during meals, in the forum, and every gathering of friends. This was John's solution to living through the crisis:

Giving our leisure to discourse respecting these things, we should be able to withdraw our soul even from this despondency that hangs over us, instead of looking with so much anxiety as we do, whilst we say one to another, 'Hath the Emperor heard what hath happened? Is he incensed? What sentence hath he pronounced?... Will he destroy utterly a city so great and populous?'... Should only ten act rightly, we shall light up a general fląme throughout the city to shine forth, and to procure us safety.

This brief survey of the five homilies, discussed above, has traced John's rhetorical response to the citizens of antioch from just 
prior to the riot through the inltial days of turmoil and uncertainty. The selected quotations provide a clear perspective of his rhetorical motivations and the desired effect he hoped they would have on his audience. Homilies IV and VII-XII reflect similar purposes as John attempted to both encourage and exhort his listeners on a day to day basis.

\section{HOMILY XIII}

\section{Setting}

In Homily XIII, delivered some three and a half weeks after the riot, John reviewed for his audience what had recently transpired in the forum. A tribunal, sent by the Emperor, had begun their investigation into the affair of the statues. The fear that had slowly died down with the passing of time had been rekindled. According to John, the mood of the city was characterized by a profound silence, suspicions between neighbors, concern over further arrests, and anxiety regarding the punishment of prisoners. ${ }^{12}$ Soldiers armed with swords and clubs stood guard, adding fuel to the volatile atmosphere. Outside the forum people could be heard imploring the judges to show mercy. others held their breath, wondering if they would be implicated in the revolt by the confessions of their beaten loved ones and friends. John described what he had seen: "one saw tortures both within and without.... There was lamentation within, and without...inside, on the part of those who were found gullty, and outside on the part of their relatives. " 43 


\section{Purpose}

John had a clear purpose in mind as he carefully communicated to his parishioners the details of the horrors he had observed before the tribunal. He wanted to "soften their hearts," persuade them to "shake off all listlessness," and shift their focus from "worldy cares" so that they might readily hear what he was about to say. ${ }^{44}$ The helpless behavior exhiblted in the presence of the earthly judges provided John with a powerful spiritual contrast. He described his inner dialogue with the words:

I said within myself, if now, when men are judges, neither mother, nor sister, nor father, nor any other person, though guiltless of the deeds which have been perpetrated, can avail to rescue the criminals; who will stand by us when we are judged at the dread Tribunal of Christ? Who will dare to raise his voice? Who will be able to rescue ${ }_{5}$ those who shall be led away to those unbearable punishments?

Many of those being trled by the Emperor's tribunal represented the wealthy upper-class of Antioch; however, John warned, their wealth, nobility, and influence were worthless in light of their crimes. He was equally convinced that the same fact would hold true on the future day of divine judgment when all would stand before God. That conviction powered his rhetoric.

HOMILY XV

\section{Setting}

This message was communicated on Saturday, three days after the homily discussed above. Circumstances in the city had not changed. The tense mood of fear created a unique rhetorical context and provided John with a receptive audience. 


\section{Purpose}

John again constructed his message around the reality of fear.

His intent in this particular homily was to demonstrate the positive impact of that fear. Fear had taught the citizens of Antioch lessons that they had failed to learn during times of complacency and security. John observed, "Discourse will not be able to effect as much as fear does. ${ }^{46}$ He illustrated his point by referring to the behavior of some within his congregation:

How many words then did we spend before this in exhorting many... counseling them to abstain from the theatres, and the impurities of these places! And still they did not abstain; but always on this day they flocked together to the unlawful spectacles of the dancers; and they held their dlabolical assembly in opposition to the full congregation of God's Church; so that their vehement shouts, borne in the air from that place, resounded against the psalms which we were singing here. But behold, now whilst we were keeping silence, and saying nothing on the subject, they of themselves have shut up their orchestra; and the hippodrome has been left deserted! Before this, many of our own people used to hasten to them; but now they are all fled hither frop thence to the church, and all alike join in praising our God!

According to John: "nothing so swallows up sin, and makes virtue to increase and flourish, as a perpetual state of dread. ${ }^{48}$ He argued that the devil had intended the dread to be destructive, but God had used the same fear to bring needed spiritual reformation to the residents of Antioch. 
HOMILY XVI

\section{setting}

The next day, the third Sunday in Lent, John delivered this homily. Rumors of a planned sack of the city were circulating among the populace. Those who crowded into the church were in a state of near panic and about to flee the city. In response to the situation, the City Prefect (Governor) had entered the church and had addressed the people. Settling the assembly down, he dispelled the rumors and gave the people fresh hope of a peaceful resolution to the crisis. Following the Prefect's successful appeal, John rose to speak:

I commend the Prefect's consideration that...he hath come here.... But for you I blushed, and was ashamed, that after these long and frequent discourses ye should have needed consolation from without. I longed that the earth would open and swallow me up, when I heard him discoursing with you, alternately administering comfort, or blaming such 1ll-timed and senseless cowardice. For it was not becoming, that you should be instructed by himi 4 gut you ought yourselves to be teachers to all unbellevers.

His ego obviously bruised, John repeatedly ventilated his anger and sorrow at their "unmanly" behavior in response to a mere rumor.

\section{Burpose}

Like a disappointed parent, John heaped guilt on his children for letting him down before the Prefect. His rhetoric focused on their failure, with the intent that the resulting shame would motivate them to a deeper level of devotion. Rather than being held captive by their imaginations, the church members should have "captured" the Prefect by their falthfulness in the face of adversity. Highlighting the qualities he wanted them to demonstrate to unbelievers, John 
communicated the following message:

This Prefect, on coming among you, ought to have admired your magnanimity, your fortitude, your perfect tranquillity; and to have gone away, taking with him a lesson from your good order, admiring your assembly, praising your congress, and learning from the actual fact, howg great a difference there is between Gentiles and Christians!

John connected their embarrassing performance with the remaining days of Lent, challenging the people to demonstrate a practical and visible change of behavior. He said: "Shew me not the wrestler in the place of exercise, but of the actual contest; and religion not at the season of hearing, but at the season of practice. ${ }^{51}$ The critical issue for John was not how many weeks his parishioners might have fasted during Lent, but whether they had been reconciled to an enemy, broken a habit of evil-speaking, conquered a problem of swearing, or displayed some other good work. 52

The priest repeated the same exhortations again and again. His stated purpose was to keep on addressing those issues until it was clearly apparent that his listeners had been fully persuaded. John attempted to follow the divine example and urged his audience to do the same: "Every day God is addressing us, and we do not hear; and yet He does not leave off speaking. Do thou, therefore, imitate this tender care towards thy neighbour. ${ }^{53}$

\section{HOMILY XVII}

\section{Setting}

A few days after he preached the above homily, the good news reached Antioch that the city was to be spared by Emperor Theodosius. The city jubilantly celebrated the reconciliation. For John it was 
time to give thanks, worshlp, and reaffirm the lessons of the crisis before they were forgotten in the excitement. He addressed the church:

Let us give thanks then, not only that God hath calmed the tempest, but that He suffered it to take place; not only that He rescued us from shipwreck, but that he allowed us $t_{94}$ fall into such distress...let us never forget these trials.

John reviewed the terror of the weeks of the crisis, especially the inquisition of the tribunal, and commended the monks who had recently come to the aid of the city during the darkest days of fear.

\section{Purpose}

Now that the crisis was over, John's main rhetorical concern was to nurture the growth of the religious revival that had started during the calamity. It was a time for prayer, tears, piety, and caution. The priest was afraid that since the "bridle" of tribulation had been removed and the "cloud" had passed away, the people would return to their former pattern of careless living. He urged them to "continue in the same state of godly fear" that had characterized their behavior during the crisis. 55

John also wanted to give proper credit to those he felt had played a major role in the deliverance of the clty. He saw a strong contrast between the behavior of Antioch's nobility, and the response of the desert monks who had interceded for the city before the dreaded tribunal. He vividly described how these hermits, upon learning of the crisis, had come to console the citizens of the city like a band of "angels." Instead of enjoying the distant safety of their caves they had willingly entered the arena of danger. ${ }^{56}$ Furthermore, these 
"weak" monks had confronted the magistrates, and had offered to give their own lives as a ransom for the residents of Antioch. John quoted

a reported speech of one of these advocates:

The statues which have been thrown down are again set up, and have resumed their proper appearance; and the mischief was speedily rectified; but if ye put to death the image of God, how will ye be again able to revoke the deed! or how to reanimate those who are 57 deprived of 1 ife, and to restore their souls to their bodies?

The action of the monks provided John with an excellent opportunity to denounce the contrasting behavior of the secular philosophers of Antioch. He attacked them with the words:

Where now are those who are clad in threadbare cloaks, and display a long beard, and carry staves in the right hand; the philosophers of the world, who are more abject in disposition than the dogs under the table; and do everything for the sake of the belly? All these men then forsook the city, they all hasted away, and hid themselves in caves! But they only, who truly by works manifest the love of wisdom, appeared as

fearlessly in the forum, as if no evil had overtaken the city. And the inhabitants of the city fled away to the mountains and to the deserts, but the citizens of the desert hastened into the city; demonstrating by deeds what, on preceding days, I have not desisted from saying, that the very furnage will not be able to harm the man who leads a virtuous life.

John's words were no doubt colored by his loyalty to his former friends of the desert, where he had spend the formative years of his own spiritual pilgrimage. By drawing attention to their brave acts he was also serving to reinforce his own credibility before his audience. They were well aware of his ties to the wilderness and would most likely connect the courage of the band from the desert with the behavior of thelr own priest.

In this homily of thanksgiving, John also wanted to underscore what he felt contributed to the dignity and greatness of a city. The Emperor had punished the city of Antloch by temporarily closing down 
the baths, the hippodrome, and the orchestra. He had also forbidden that Antioch should be designated as a "metropolis" within the Empire. These penalties injured the civic pride of the residents of Antioch. John saw the situation differently. These imperial decrees were, according to John, a "correction, his punishment a discipline, his wrath a means of instruction. ${ }^{59}$ John continued:

Dost thou grieve that the dignity of the city is taken away? Learn what the dignity of a city is; and then thou wilt know clearly, that if the inhabitants do not betray it, no one else will be able to take away the dignity of a city! Not the fact that it is a metropolis; nor that it contains large and beautiful buildings; nor that it has many columns, and spacious porticoes and walks, nor that it is named before other cities, but the virtue and piefy of its inhabitants; this is a city's dignity, and ornament.

Having impressed on his audience the need for continued plety, having applauded the courage of the monks, and having affirmed the true dignity of a city, John concluded his homily. He urged his listeners not to forget, in their excitement, the plight of those fellow members still behind bars. His final words of warning were; "Let no one say, 'What farther concerns me? I am freed from danger.' Let us not provoke God by this indifference. ${ }^{61}$

\section{HOMILY XXI}

\section{Setting}

The final homily in John's series, on The Statues, was preached on Easter Sunday, approximately three weeks after the message discussed above. Bishop Flavian, who had traveled to Constantinople on behalf of the city of Antioch, had returned in time to foin the resurrection festivities. John learned from the Bishop the details of 
what had transpired when Flavian had entreated the Emperor Theodosius to forgive the city's treasonous crimes. Their reunion with the Bishop, plus their joy over a crisis that was past, multiplied by the church's celebration of Easter all added up to create a powerful occasion for John's final message on the affair of the statues.

\section{Purpose}

John's purpose was clearly to guide the audience in reliving the drama of the crisis. Flavian's dialogue with the Emperor, embellished for rhetorical effect, was communicated in great and moving detail. Every argument, every move and countermove, were graphically and dramatically acted out in words. By the time John reached the climax of the story and the Emperor had pronounced his words of forgiveness, his audience must have felt as if they were right there in the Emperor's chambers, listening to every word as it was spoken. Portraying the account in this fashion must have aided the audience in retaining a vivid picture of what had taken place. John's eloquent masterpiece was the fourth century's closest thing to a video tape of the event.

Having etched the elaborate account on the minds of his listeners, John quickly closed his address with these final words of application:

What therefore ye then did, in decking the forum with garlands; lighting lamps, spreading couches of green leaves before the shops, and keopling high festival, as if the clty had fust come into being, this do ye although in another manner, throughout all time;--being crowned, not with flowers, but with virtue;-kindling in your souls the light which comes from good works; rejolcing with a spiritual gladness. And let us never fail to give God thanks continually for all these things.... For the 
history of what has lately happened to us, will have power to profit not only ourselves, if we constantly remember it, but also those who shall come after us.

\section{SUMMARY}

In this chapter I have examined the specific settings and purposes of ten selected homilies from John's series, on The statues. The primary focus has been to analyze these homilles in terms of John's crisis rhetoric. It is clear that John adapted his rhetoric to the changing state of affairs in the city of Antioch. He was sensitive to the emotions and needs of his audience and carefully integrated his material into the context of their experiences. Two general purposes repeatedly surface in his sermons. His first objective was to comfort and calm his troubled parishioners through words of encouragement.

His second task, pursued with equal fervor, was to challenge his congregation to more virtuous living. His exhortations were generally practical and frequently focused on matters of communication such as slander and swearing. John repeatedly reminded his audience of their progress toward these spiritual goals and continued to stress the importance of these priorities after the crisis had been resolved.

I have also briefly introduced a wide variety of John's favorite themes in this survey of John's preaching response to the crisis of A.D. 387. In the next chapter, I will attempt to draw these varlous themes together in order to create a holistic plcture of John's rhetorical vision of crisis. 


\section{CHAPTER IV NOTES}

1 Chrysostom, on The statues, IV.1.

2 Chrysostom, I. 32, 33.

3 Chrysostom, I. 32 .

4 Chrysostom, I. 32

5 zosimus, V. 24.

6 Chrysostom, I.1.

7 Chrysostom, I.2.

8 Chrysostom, I.30.

9 Chrysostom, I.10.

10 Chrysostom, II.1.

11 Chrysostom, II. 4.

12 Chrysostom, II.5.

13 Chrysostom, II.13. The Biblical reference is I Timothy $6: 17$.

14 Chrysostom, II.16.

15 Chrysostom, II.1.

16 Chrysostom, II 10.

17 Chrysostom, II.10.

18 Chrysostom, II.26.

19 Chrysostom, II.12.

20 Chrysostom, II.11.

21 Chrysostom, III.17.

22 chrysostom, III.7.

23 Chrysostom, III.20.

24 Chrysostom, III.11.

25 zosimus, V.22,23; socrates, VI.3-21; Sozomen, VIII.2. 
26 Chrysostom, III. 20.

27 Chrysostom, III. 19.

28 chrysostom, III.6.

29 Chrysostom, III.6.

30 Chrysostom, IV.17.

31 Chrysostom, IV. 4.

32 Chrysostom, V. 6 .

33 Chrysostom, v.11.

34 Chrysostom, V.14.

35 chrysostom, v. 19.

36 chrysostom, VI. 3 .

37 Chrysostom, VI. 3.

38 Chrysostom, VI. 6.

39 Chrysostom, VI.1.

40 Chrysostom, VI.6.

41 chrysostom, VI.18.

42 Chrysostom, XIII.2.

43 Chrysostom, XIII.3.

44 Chrysostom, XIII.7.

45 chrysostom, XIII.4.

46 chrysostom, XV.1.

47 Chrysostom, XV.1.

48 Chrysostom, XV. 2 .

49 Chrysostom, XVI.1.

50 chrysostom, XVI.7.

51 chrysostom, XVI.4. 
52 Chrysostom, XVI.13.

53 Chrysostom, XVI.17.

54 Chrysostom, XVII.1.

55 Chrysostom, XVII. 2.

56 Chrysostom, XVII.3.

57 Chrysostom, XVII.3.

58 Chrysostom, XVII.5.

59 Chrysostom, XVII.9.

60 Chrysostom, XVII.10.

61 Chrysostom, XVII.15.

62 Chrysostom, XXI.20. 
CHAPTER $\mathrm{V}$

JOHN CHRYSOSTOM: HIS RHETORICAL VISION

\section{INTRODUCTION}

To this point I have traced the various factors that deeply influenced the llfe of John Chrysostom. In Chapter II, I examined the unique integration of John's home environment, his secular rhetorical training, and his intense religlous experiences. The political, social, economic, and religlous elements of John's historicalrhetorical context were analyzed in Chapter III. H1s evolving oratorical response to the Antiochene crisis of A.D. 387 was the subject of chapter IV. Building on this essential foundation, my purpose in the present chapter is to further investigate and analyze the specific characterlstics of John's rhetorical vision of the crisis.

The concept of "rhetorical vision" 1 is used to describe the way John combined his varlous themes into a coherent interpretation of what was happening in Antloch. John's homilles were his communicative attempt to make sense out of the crisis, both for himself and his troubled audience. By dramatizing certain themes, already familiar to his audience, John sought to convince his listeners to adopt his viewpoint of the crisis and respond accordingly.

such dramatic rhetorical scrlpts are labeled as "fantasy themes" by Ernest Bormann. As part of his "symbolic convergence" 
commmunication theory, Bormann describes how the sharing of group

fantasies can create an entire social reality for the group's

participants. He writes:

Fantasy is a technical term in the symbolic convergence theory and does not mean what it often does in ordinary usage, that is something imaginary, not grounded in reallty. The technical meaning for fantasy is the creative and Imaginative interpretation of events that fulfills a psychological or rhetorical need. The scholar working to reconstruct the consciousness embodied in the sharing of rhetorical fantasies of the past must depend heavily upon the traces left in the messages that created those fantasies. Rhetorical fantasies may include fanciful and fictitious scripts of imaginary characters, but they often deal with things that have actually happened to members of the community or that are reported in authenticated works of history, In the news media, or in the oral history and folklore of the group. The content of the dramatizing message that sparks the fantasy chain is called the fantasy theme.

These fantasy theme "traces," suggested above by Bormann, are clearly evident in the rhetoric of John Chrysostom. By continually reafflrming certain crisis themes to his audience, John nurtured the group's sense of what it meant to be a Christian in the pluralistic culture of Antioch. He gave his listeners a new subcultural identity. Bales describes this type of fantasy building process as follows:

The culture of the interacting group stimulates in each of its members a feeling that he has entered a new realm of reality--a world of heroes, villains, saints, and enemies--a drama, a work of art. The culture of a group is a fantasy established from the past, which is acted upon in the present. In such moments... one is "transported" to a world which seems somehow even more real than the everyday world. One may feel exalted, fascinated, perhaps horrifled or threatened, or powerfully impelled to action, but in any case, involved. One's feelings fuse with the symbols and images which carry the feeling in communication and sustain it over time. One is psychologically taken into a psychodramatic fantasy world. ${ }^{3}$

This process, 1dentifled by Bales as a function of small group

Interaction, can also be readily applled to John and his mass 
communication appeals to the citizens of Antioch. He sustained the Christians' sense of community, while at the same time strongly motivating them to take specific steps of action in line with the rhetorical vision he had created. ${ }^{4}$

Fantasy theme analysis is characterized by a unique taxonomy of terms (See Chapter I, page 8). This dramatistic approach provides a valuable framework for analyzing narrative materials like John's homilies. However, one major criticism of fantasy theme analys is is the tendency of critics to employ the vocabulary in an imprecise or arbitrary fashion. Therefore, while I draw from the concepts of this critical method, I have not chosen to subdivide John's dramatic scripts into separate and distinct categories of themes, cues, types, and visions. In this thesis I utilize the general term "theme" in describing the major dramas that comprised John's rhetorical vision of the crisis.

In this chapter I discuss the five dominant fantasy themes which characterized John's rhetorical vision. The themes are drawn from an analysis of the ten selected homilies from on The Statues, surveyed in the last chapter. These unifying themes are presented as follows:

1) CRISIS: A SUPERNATURAL DRAMA

2) CRISIS: A TRANSFORMATIONAL DRAMA

3) CRISIS: A JUDGMENT DRAMA

4) CRISIS: A SOCIAL DRAMA

5) CRISIS: AN EVANGELISTIC DRAMA

Following this descriptive analysis of John's themes, I conclude the chapter with a critical evaluation of the priest's rhetorical 
vision. In this section I address such concerns as the quality, appropriateness, and consistency of John's rhetoric. Since John attempted to dramatically reconstruct the world view of his audience through his rhetoric, it is also important to consider the possible effects his homilies had upon the consciousness and actual behavior of his parishioners. We focus on these issues by examining flrst the strengths and then the weaknesses of John's rhetorical vision.

\section{CRISIS: A SUPERNATURAL DRAMA}

Following the riot, John immediately recast the historical circumstances of the crisis into a spiritual script complete with actors and dramatic plot. Throughout the weeks of the crisis he continued to embellish this fantasy theme. It was as if John and his congregation were spectators, seated in a great cosmic theatre, watching a divine conflict unfold before their eyes.

\section{The Actors}

The main characters in John's scripts were the devil and God. Their contrasting purposes stood behind all that had taken place in the city of Antioch. Demons and angels made up the supporting cast. John dressed the human instigators of the crisis in demonic costumes. According to John the "accursed and pernicious characters" 5 who perpetrated the crime of tearing down the Emperor's statues were in reality Satan's emissaries. For John the city had been "bewitched by demons." ${ }^{6}$ John played out the theme in recounting for his audience the imagined dramatic dialogue between Blshop Flavian and the 
Emperor. John put the following words in the Blshop's mouth as he appealed to the angered Theodosius:

The demons have lately used all their efforts, that they may effectually rend from your favour that city which was dearest of all to you. Knowing this then, demand what penalty you will, but let us not become outcasts from your former love! Nay, though it is a strange thing, I must say, display towards us now still greater kindness than ever, and again write this city's name among the foremost in your love;--if you are indeed desirous of being revenged upon the demons who were the instigators of these crimes! For if you pull down, and overturn, and raze the city, you will be doing those very things which they have long been desiring. But if you dismiss your anger, and again avow that you love it even as you did before, you have given them a deadly blow... and you would be just in acting thus, and in shewing mercy tq a city, which the demons envied on account of your affection.

In contrast with these diabolical agents of crisis, John described the monks who came to the aid of the distressed city as "so many angels arriving from heaven. ${ }^{8}$ These human-divine messengers were willingly to lay down their very lives as a sacrifice in order to preserve Antioch from the assaults of the Enemy and his troops. In John's rhetorical vision the monks, the Bishop, and the priests represented the purposes of God in the crisis. God was not distant from, nor disinterested in, the troubled state of the Antiochenes. He too was acting to win the city for himself. ${ }^{9}$

The Plot

The 0ld Testament story of Job became John's master analogy ${ }^{10}$ in characterizing this supernatural drama for his audience. In his first homily, delivered a week before the crisis, John had introduced Job as a supreme example of virtuous living in the face of unfair demonic attacks. John spoke: 
For when Job was surrounded with great wealth, and enjoyed much opulence, that wicked demon, being reproached by God on his account, and have nothing to say; when he could neither answer the accusations against himself, nor impugn the virtue of this just man; took refuge at once in this defense, speaking thus, 'Doth Job fear thee for nought? Hast thou not made a hedge about him on all sides. For reward then,' saith he, 'that man is virtuous, enjoying thereby so much opulence.' What then did God? Being desirous to show, that it was not for reward that his saints serve Him, he stripped him of all his opulence; gave him over 1 fo poverty; and permitted him to fall into grievous disease.

The scriptural plot of Job's story provided John with graphic materlal for developing his own fantasy theme for the Antiochene audience. This repeated theme occupied center stage in John's rhetorical vision of the crisis. The heavenly drama of the old Testament was being enacted again in the city of Antioch. It was as if Satan had again entered the heavenly courts complaining that the Chrlstlans of Antloch served God only because they lived in such ease and luxury. John vividly articulated his comparison:

He [Job] then sat down on his dunghill; she [Antloch] is now seated in the midst of a great snare. For even as the devil then leaped violently the flocks, and herds, and all the substance of the just man, so now hath he raged against this whole city. But then, as well as now, God permitted it; then, indeed, that he might make the just man more illustrious by the greatness of his trials; and now, that he may maks us more sober-minded by the extremity of this tribulation.

John even enacted elements of the Biblical story by remaining silent for seven days after the riot. In the old Testament account, Job's friends, upon hearing of his tragedies, came to support him in his crisis. Before they uttered a word in response to their friend's pain, they silently sat with him for seven days in a spirit of lamentation. 13 John called the Antioch's nelghboring cities to come, like Job's friends, and lament with all sympathy what had happened to 
the great city. He also dramatically underscored his thematic plotline by his own symbolic act of silence. John described his rhetorical motivation with these words: "Suffer me to mourn over our present state. We have been silent seven days, even as the friends of Job were. Suffer me to open my mouth today, and to bewail this common calamity." 14

When John's congregation was panic stricken by rumors that troops were coming to destroy the city, he again employed the Job theme to remind his listeners of their appropriate response to the supernatural drama in which they were participants. He addressed them with the appeal:

Thou hadst heard indeed a false report of the march, and wert in danger of being severed from the present life. But that blessed Job, when the messengers came one after another, and he had heard them announcing their dreadful news, and adding thereto the insupportable destruction of his children, neither cried nor groaned, but turned to prayer, and gave thanks to the Lord. Him do thou too imitate; and when any comer announces that soldiers have encircled the city, and are about to plunder its wealth, flee to thy Lord and say, 'The Lord gave, the Lord hath taken away; as it seemeth good to the
Lord, so it is done. Blessed be the name of the Lord forever. ${ }^{2}$

These examples demonstrate John's careful use of the Job analogy in creating a vivid supernatural script for his audience. By systematically repeating and rephrasing elements of the Job story, he was able to direct his congregation to respond in line with his rhetorical vision. Once the theme was embedded in the consclousness of his people, John only had to mention "Job" and the crowd would "see" their crisis circumstances in the context of a Heaven-Hell, Divine-Demonic confllct. Bormann describes the function of such a master analogy as follows: 
The master analogy pulls the various elements together into a more or less elegant and meaningful whole. Usually, a rhetorical vision is indexed by a key word, a slogan, or a label. Such indexing is a special case of symbolic cuing phenomenon, but in this instance, the rhetorical community has reached such a high level of symbolic maturity that the cryptic allusion can be not just to details of fantasy themes and types but t ${ }{ }_{6}$ a total coherent view of an aspect of their social reality.

The "Job" label was, to John and his audience, what such labels as "The New Deal," "Black Power," or "The Moral Majority," have been to more contemporary groups and speakers. 17

In John's mind, the crisis of the statues reflected the deeper "reality" of a supernatural drama between God and his angels and Satan and his demons. This drama provided John with an answer to the fundamental cosmic question of "Who" was in charge of the world. All of his subsequent rhetorical fantasy themes were based upon this foundational drama.

\section{CRISIS: A TRANSFORMATIONAL DRAMA}

The conclusion of the Biblical story of Job strongly supported John's second theme. In Job's case, God's goodness triumphed over the evil schemes of the devil. Job was richly rewarded, physically and spiritually, for his faithfulness while under the stess of extreme crisis. John was convinced that the people of Antioch could reap the same positive results from their time of testing. He was equally certain that the peaceful resolution of the Antiochene crisis had had its basis in the dramatic transformation of evil to good.

Bormann identifies a similar drama in the sermons of America's Puritan preachers. He contends that they made clear rhetorical use of 
times of calamity in developing their "Fetching good out of evil" fantasy message. To the puritan preachers and followers nothing happened by chance. Times of success were interpreted as signs of spiritual blessing, while troubles and hardship were viewed as the visible results of having offended God in some way. Bormann writes:

Evil always has a purpose since God does not afflict his chosen people with troubles unless they are failing to live up to the covenant he has with them. The community members and its spokesmen must, therefore, search the evil and discover the good within it. The participant does not wring his hands in the face of evil and say, 'How meaningless' or 'Why me?' 'Why does this happen to me?' Rather the participant in the 'Fetching Good out of Evil' fantasy type 1 asks, 'How have I sinned?' 'What must we do to be saved?'

In simllar fashion, Chrysostom developed and expounded his transformatlonal drama.

\section{The Actors}

The citizens of Antioch, particularly those crowded into John's church, were asked to imaginatively leave their spectator seats and become actively involved in the supernatural drama. God was willing and able to do his part in triumphantly conquering all the evil effects of the terrible crisis. However, the people of the city also needed to assume their appropriate roles. John rehearsed his scripts for his listeners on a number of different levels. The transformational drama was first and foremost an intrapersonal drama of conversion, of personal virtue winning out over vice. The characters in John's audience were also to adopt new Interpersonal roles. They were challenged to reform their behavior in relationships with family, friends, and enemles. To these two actor dimensions, John added a larger corporate responslbility. Individuals with 
changed beliefs, values, and priorities would have an impact upon the entire city, bringing a significant social transformation to the whole culture of Antioch.

\section{The Plot}

John's formula for turning the evil of the crisis to a redemptive conclusion was relatively simple. First of all, the backdrop for this drama was his conviction that past crises, as well as the present distress, symbolized God's punishment of the city. There was no cause and effect question in John's mind. The purpose was clearly proclaimed by the priest: "It is because thou hast sinned, that He is indignant. ${ }^{19}$ John supported his point by graphically describing a type of spiritual surgery with the words:

Suppose any one hath a wound; which is the most deserving of fear, gangrene, or the surgeon's knife? [sic] the steel, or the devouring progress of the ulcer? Sin is gangrene, punishment is the surgeon's knife. As then, he who hath a gangrene, although he is not lanced, hath to sustain the malady, and is then in the worse condition, when he is not lanced; so also the sinner, though he be not punished, is the most wretched of men...so those who live 20 in iniquity, if they are punished, may have favorable hopes.

The calamity, resulting from the overturning of the Emperor's statues, was yet another opportunity for Antloch's earthly actors to get the divine message of needed correction. John urgently exhorted his audience that their failure to benefit from the present chastisement would only lead to more painful crises in the future. According to John:

For many times, when we have been surprised by earthquakes, as well as famine and drought, after becoming more sober and gentle for three or four days, we did but return again to the former course. For this cause our present troubles have 
happened. But if we have not done so before; yet, now at least let us all persevere in the same piety; let us persevere in the same meekness, that we may not again need another stroke. Was not God able to have prevented what has taken place? He did, however, permit it, that He might make those who despised Him more sober-minded, through dread of a fellowservant!

If the citizens of the city accepted this truth and truly reformed their lives they would then experience the glorious blessing of a peaceful resolution to the entire affair. John repeatedly set this "If-then" script before his congregation. The following examples reflect this aspect of John's transformational fantasy theme:

If we thus set our lives in order, I warrant you and promise, that from this there will be deliverance from the present calamity, and a removal of these dreadful ills; and what is greater than al\}, there will be the enjoyment of the good things to come.

I understand this much of the future, and I proclaim, both loudly and distinctly, that if we become changed, and bestow some care upon our souls, and desist from inlquity, nothing will be unpleasant or painful. And this I plainly know from the love of God toward man, as well as from those things which He hath 23 done for men, and cities, and nations, and whole populations. 23

If we thus regulate ourselves, none of these heavy events which may befal [sic] us will give us pain; but from those things which may seem to be grievous, we shall be even gainers, and loss will be sweeter and more desired than wealth, pain than pleasure, and mirth and inglt than honour. Thus all things adverse will turn to our gain.

John outlined a clear pattern of reform for his audience. Using the clrcumstances of the actual riot, he dramatized their need to radically change their communication behavior. Evll speaking, foul language, blasphemy, speaking 111 of one's neighbor, and speaking 111 of God were all condemned as unacceptable. It was just such speech that had provoked the riotous actions of the mob. John Intensifled his appeals by fusing together vivid details of recent events with a 
spiritual-transformational message. For example, John dramatized the problems of slander and greed with these words:

For many of our evil speakers have run into such madness, as to $11 \mathrm{ft}$ up their own tongue from their fellow servants against their Master. But how great an evil this is, you may learn from the affairs in which we are now involved. $A$ man is insulted, and 10, we are all fearing and trembling, both those who were guilty of the insult, and those who are conscious of nothing of the kind! But God is insulted every day... but He forbears, and suffers long, and still offers to pardon those who have insulted $\mathrm{HIm}$.... How many men have not only cast down, but also trodden under foot the images of God! For when thou throttlest a debtor, when thou strippest him, when thou
draggest him away, thou tramplest under foot God's Image.

In another context, John compared the daily practice of certain virtues with the paying of taxes. It had been frustration with an increase in taxes that had provoked the sedition. By combining these ideas, John captured the attention of his audience and provided them with a new spiritualized script.

And as when we hear that some money tax is imposed, each one going within, and calling his wife and chlldren and servants, considers and consults with them how he may pay this tribute, so also let us do with respect to these splritual precepts. Let every one when he has returned home call together his wife and children, and let hIm say, that a spiritual tribute was imposed this day: a tribute by which there will be some deliverance and removal of these evils; a tribute which does not make those who pay it poor, but richer; that is to say, to hazye no enemy, to speak evil of no man, and to swear not at all.

During the weeks of the crisis, John was quick to focus his audience's attention on the wonderful reforms that had resulted from the calamity. God was indeed transforming the evil to good. John encouraged his despondent followers, assuring them that they should rejoice, rather than mourn, over the blessed state of affairs. God had frustrated the devil's wishes and by means of the adversity had accomplished a miracle in Antioch. John described the scene: 
For our city is being purified every day; and the lanes and crossings, and places of public concourse, are freed from lascivious and voluptuous songs; and turn where we will there are supplications, and thanksgivings, and tears, instead of rude laughter; there are words of sound wisdom instead of 27 obscene language, and our whole city has become a Church.

Once the crisis had been peacefully resolved, John immediately brought his transformational plot to an appropriate climax. He began and concluded his final homily in the series with the same dramatized message. It was time to celebrate God's glorious victory. The spiritual equation was complete in all its parts. First, God had used the devil's strategies to correct his people. Secondly, both Christians and pagans had been "converted" through the impact of events. As a result, God saved the city from destruction. In John's words: "God, by means of this calamity, hath adorned the city, the Priest, and the Emperor; and hath made them all more illustrious....He ever disposes all things for our advantage." 28

\section{CRISIS: A JUDGMENT DRAMA}

The legal ramifications of the crisis provided John with ample material for a third fantasy theme. Prisoners were being executed for their complicity in the crimes against the Emperor. Others were waiting to stand trial. The Emperor had sent his legal representatives to Antioch to fully investigate the crimes and carry out justice. Citizens were fearful of further arrests. Members of John's congregation were perplexed by the apparent infustices that had transpired. They felt that some innocent parties had suffered unfairly, while others who were guilty had managed to escape detection and punishment. John perlodically updated his audience with hls own 
eye-witness accounts of courtroom proceedings. ${ }^{29}$ More importantly, from a rhetorical point of view, John utilized the legal scenario to dramatize a message of future divine judgment.

\section{The Actors}

For the earthly judges of Antioch, John substituted a heavenly judge: Jesus Christ. He translated his audience from the present legal crisis to a future heavenly courtroom scene. All of his listeners would one day have to stand before that righteous Judge. There would be no way of escape, no mockery of justice. For John, the concerns of the earthly city of Antioch were insignificant compared to the splendor of the heavenly city and the threat of an eternal hell. ${ }^{30}$

\section{The Plot}

John fashioned the script for this fantasy drama by contrasting a series of possible "realities" for his audience. His first rhetorical dichotomy weighed the suffering of the present crisis against the Christians' future hope. The Emperor or earthly judge might have the power to carry out a sentence of death, but only the heavenly fudge had the power to bestow eternal life. John's rhetoric was characterized by frequent appeals to his audience to boldly endure the present pain by visualizing their future deliverance. John reasoned:

It is evident that our affairs are not bounded within the limits of this present state; and this becomes manifest from our trials. For God could never suffer those who have endured so many and so great evils, and who have spent all the present $11 \mathrm{fe}$ in trials and dangers without number, to be without a recompense of far greater gifts;... it is certain that he has prepared another, a better and brighter life, in which he will 
crown those who have wrestled in the cause of godliness, ąnd proclaim their praises in the presence of the whole world.

The preacher chastized his listeners for fearing the reality of physical death while neglecting to tremble over the conseguences of their sin. The urgency of the present crisis afforded an opportunity for the Christians of Antioch to demonstrate their falth and if necessary die as martyrs. ${ }^{32}$ No matter what the outcome of the crisis they would still be winners.

Secondly, John contrasted the apparent injustices of the present circumstances with the perfect equity of the divine judgment. John was convinced that the guilty would pay for their crimes. He was also certain that what appeared to be unfair punishment might in fact be payment for a previously overlooked sin. John counseled his parishioners by anticipating their questions and engaging them in a dramatic dialogue:

But let not any one say, that many of the guilty escaped, and that many of the innocent incurred punishment. For I hear of numerous persons who frequently say this; not only in the case of the present sedition, but also in many other circumstances of this nature. What then should I reply to those who make such observations? Why, that if he who was captured was innocent of the present sedition, he had wrought some other transgression before this still more grievous, for which, not having afterward repented, he has paid the penalty at the present time. For thus is the custom of God to deal with us. ${ }^{33}$

Lastly, John vividly dramatized the outcomes of the future "Day" of divine fudgment. There would most certainly be heavenly rewards for the falthful. There would also be the eternal damnation of hell for the unconverted. John used this theme to motivate his congregation to change their behavior while there was still time. He culminated his fantasy theme with the following argument: 
Would you have me declare unto your Charity, whence it is that we are afraid of death? The love of the kingdom hath not penetrated us, nor the desire of things to come inflamed us: otherwise we should despise all present things.... Add to this, on the other hand, that we do not stand in awe of hell; therefore death is terrible. We are not sensible of the unsufferable nature of the punishment there, instead of sin, we fear death; since if the fear of the one held possession of our 3 gouls, the fear of the other would not be able to enter.

For those who shared in John's construction of reality, the persuasive impact of his fudgment drama must have been overwhelming. HIs stark polarizations of the present with the future, infustice with perfect equity, and heaven with hell, were loaded with staggering implications. John's intense symbolism of the future became a powerful fantasy theme cue, triggering a range of emotional responses from hope and commitment on the one hand, to fear and guilt on the other.

\section{CRISIS: A SOCIAL DRAMA}

The social system of Antioch was based upon rather rigid economic divisions. A peasant farming population occupied the bottom rung of the social ladder. The upper class was comprised of wealthy and well-educated professionals and included civic leaders, lawyers, veterans, prominent teachers, doctors, and influential clergy. John had experienced both social extremes. He had been born into the upper class, but had voluntarily exchanged that status for the intense ascetic life of a poor desert monk. Throughout his career as a priest, John was torn by the tension of these two contrasting life styles. As a priest he saw the clergy amassing prestige and economic power. However, John was never comfortable in plush surroundings. He 
frequently spoke out against the church's abuse of resources and her neglect of the poor.

The crisis of the statues had directly involved many of Antioch's socially elite. A number of these rich and powerful leaders of the community had been jailed and were awaiting trial for treason. The dominant and financially secure were now common criminals. This radical reversal of social standing gave John an opportunity to express his value system in the form of another dramatic fantasy script complete with social and spiritual implications.

\section{The Actors}

John drew his characters from a variety of sources. He illustrated his theme with Biblical sketches of those who had been poor in the world but rich in spirit. He exhorted his listeners with the words:

Remember the Apostles, who lived in hunger, and thirst, and nakedness; the prophets, the patriarchs, the just men, and you will find all these not among the rich or luxjurious, but among the poor, the afflicted, and the distressed.

John contrasted the bravery of the poor monks who had traveled from the wilderness to ald the citizens of Antioch, with the cowardly behavior of those rich citizens who had fled the city for safety in the desert. 36

The preacher also invited his audlence into the drama by repeatedly emphasizing the vanity of earthly fame, fortune, and power. John felt there was a critical lesson to be learned from what had happened to the wealthy of Antioch during the crisis. 
The plot

The key thrust of John's fantasy theme was the paradoxical contrast of wealth and poverty. Those who were extremely rich could also be tragically weak and helpless. John rhetorically dramatized the scene he had observed outside the courtroom:

As for me, while I sat and beheld all this, how matrons and virglns, wont to live in seclusion, were now made a common spectacle to all; and how those who were accustomed to lie on a soft couch, had now the pavement for their bed; and how they who had enjoyed so constant an attendance of female servants and eunuchs, and every sort of outward distinction, were now bereft of all these things; and grovelling at the feet of every one, beseeching him to lend help by any means in his power...I exclaimed, in those words of solomon, 'Vanity of vanities, all is vanity.' For I saw both this and another oracle fulfilled in every deed which salth, 'All the glory of man is as the flower of grass.'...For then, indeed, wealth and nobility, and notoriety, and the patronage of friends, ang kinshlp and all worldly things, were found worthless.

For John, the circumstances of the crisis again demonstrated the translent nature of physical prosperity. He focused the attention of his audience on this reality, "he who is rich today, is poor tomorrow." John continued:

For although riches may remain with us all our lifetime, undergoing no change, we must transfer them in the end, whether we will or not into the hands of others; having enjoyed only the use of them, and departing to another 1 ife naked and destitute of this ownership!

Having scripted the potential poverty of wealth, John reversed the paradox and stressed the possible wealth of the poor. According to John:

Let us not consider riches to be a great good; for the great good is, not to possess money, but to possess the fear of God and all manner ot piety. Behold, now if there were any righteous man here, having great boldness toward God, notwithstanding he might be the poorest of mortals, he would 
be sufficient to liberate us from the present evils! For he only needed to spread forth his hands towards heaven, and to call upon God, and this cloud would pass away! But now gold is treasured up in abundance; and yet it is more useless than mere clay for the 9 purpose of deliverance from the impending calamities!

John further spiritualized his theme. The rich might lavishly decorate their homes with external trappings and yet neglect the internal development of their lives, "letting their soul abide desolate and squalid, and full of cobwebs." 40 John proclaimed his rhetorical answer to this social dilemma, "Wouldest thou be rich? Have God for thy friend, and thou shalt be richer than all men! "4l John brought his social fantasy theme to a climax by expanding the drama to include the whole social order of the city. Antioch was famous for its standing as a major metropolis. The social life of her inhabitants was enhanced by famous festivals and the illustrious olympic Games. The events of the riot had devasted civic pride. The Emperor had shut down their extravagant forms of entertainment and had reduced the city's cherished position in the eastern part of the Empire. 42

Building on these facts, John constructed two contrasts. First of all, he described what he felt brought "true" dignity to a city. The real glory of a city was not found in buildings, art, titles, or landscapes. In John's rhetorical vision the important issue was not being a metropolis on earth, but earning that designation in heaven. spiritual virtue and piety were the "ornaments" of John's restored city. In his own words, "To me, a city that hath not pious citizens is meaner than any village, and more ignoble than any cave." 43 
In addition, John challenged his audlence to visualize the radical difference between the earthly city of antioch and their eternal heavenly city. John rhetorically pictured the difference:

If thou art a Christian, no earthly city is thine. of our City 'the Bullder and Maker is God.' Though we may gain possession of the whole world, we are withal but strangers and sojourners in 1t all! We are enrolled in heaven: our citizenship is there! Let us not, after the manner of little children, despise things that are great, and admire those which are little! Not our city's greatness, but virtue of soul is our ornament and defence. If you suppose dignity to belong to a city, think how many persons must partake in this dignity, who are whoremongers, effeminate, depraved, and full of ten thousand evil things, and at last despise such honour! But that City above is not of this kind; for it is impossible that he can a partaker of it, who has not exhibited every virtue.

It is not difficult to discern the influences of John's own spiritual experiences in the formation of this social drama. His psyche was deeply imprinted with the value of self-denial. The spiritual lessons of his former desert cave convinced him of the paradoxical wealth of poverty. This social reality made sense to John and the evidence from the crisis reinforced his rhetorical vision. John's fantasy theme must have also appealed to the many economically depressed persons in his congregation. No doubt the preacher's rhetoric, concerning the vivid status reversal of Antioch's socially elite, brought forth cheers and applause from those who had envied such wealth. They too, could find meaning and identity in accepting their physical poverty as a symbol of their greater capacity for abundant spiritual resources. Embracing their priest's dramatic vision also helped them to weather the uncertainties of the days of 
crisis. If their earthly home was destroyed they were assured of an eternal one. In the interim, their faithfulness on earth would be accruing heavenly interest.

\section{CRISIS: AN EVANGELISTIC DRAMA}

The setting of crisis also provided John with a unique opportunity to dramatically articulate a clear fantasy theme concerning the nature and mission of the church. The priest was convinced that the church played the central role in preventing crises in society. He believed, as well, that the church was to triumphantly lead the way through crisis. Christians were to act out their parts on the stage of pagan culture. John continually integrated this missionary theme into the subject matter of his crisis homilies.

\section{The Actors}

John began his evangelistic drama by parading before his listeners the heroes of faith who had founded the church in Antioch. The historical record of the church was filled with examples worthy of emulation. John was persuaded that the past accomplishments of these saints, in times of persecution and calamity, had definite present meaning for his audience. If they were willing to accept their role in the evangelistic drama, history would record thelr zealous deeds as we 11 .

\section{The Plot}

John characterized the unique identity of the church by creating a rhetorlcal polarization between insiders and outsiders. HIs "us" and 
"them" vision of reality dominated his vlew of the world and fueled his rhetoric. John pronounced this assertion in his first homily:

Let the Jews and Greeks learn, that the Christians are the saviours of the clty; that they are Its guardians, its patrons, and its teachers. Let the dissolute and the perversye also learn this; that they must fear the servants of God too.

In John's mind, the church at Antloch was especially unique and had a significant reputation to maintain. John frequently reminded his followers of their valuable heritage and responsibility. He unfolded his rhetorical argument as follows:

For our city is dearer to Christ than all others both because of the virtue of our ancestors, and of your own. And as Peter was the first among the apostles to preach Christ, so as I said before, this city was the first of cities that adorned itself by assuming the Christian appellation, as a sort of admirable diadem. But if where only ten just men were found, God promised to save all who dwelt therein, why should we not expect a favourable issue, and become assured of all our lives, when there are not only ten, twenty, or twice so mąpy only, but far more; who are serving God with all strictness.

John challenged his listeners to see themselves, first of all, as preventors of crisis. It was their responsiblity to correct those whose actions threatened the welfare of the city. Prior to the outbreak of the tax riot, John pleaded with his congregation to infiltrate the community and do whatever was necessary to "correct...the blasphemers of the city." 47 John even advocated the use of physical violence to restrain the influences of evil persons. ${ }^{48}$ John warned them of the urgent task:

But when not merely one, or two, or three, but so great a multitude are able to take on them the care of the neglected, it is in no other way but are our own supineness, and not from our want of strength, that the majority perish and fall....If, perchance, we see an ass fallen down, we all make haste to stretch out a hand to raise him up. Yet we neglect our perishing brethren! The blasphemer is an ass, unable to bear 
the burden of his anger, he has fallen. Come forward and raise him up, both by words and by deeds; and both by meekness and by vehemence; let the medicine be various. And if we thus administer our own part, and take pains for the safety of our neighbors, we shall soon become objects of desire and affection to the very persons who have the benefit of our correction. ${ }^{49}$

John soundly chastised his audience for their passivity. The outbreak of the crisis was the direct and painful result of their failure to follow his instructions. According to John, "If we had taken them in time, and cast them out of the city, and chastised them, and corrected the sick member, we should not have been subjected to our present terror." 50

Having failed to prevent the crisis, the church was faced with a new opportunity. John expanded his fantasy theme by dramatizing the church's evangelistic agenda for the weeks of uncertainty and fear. John verbalized three essential roles for the church during the crisis.

First, the church was to provide stablizing comfort both to her members and to the larger community. In John's words, "the Church, which is the common mother of us all, opening her bosom, and cradling us in her arms, administers dally consolation." 51

In addition, the church was again to embrace the task of correction. John was not satisfied with the fact that the church was filled with those seeking encouragement. There was work to be done. John warned them of what would happen If they did not carry out their evangelistic assignment:

The Church is not a theatre, that we should listen for amusement. With profit ought we to depart thence, and some fresh and great galn should we acqulre ere we leave this place. For it is but vainly and Irrationally we meet together, if we 
have been but captivated for a time, and return home empty, and void of all improvement from the things spoken.... Let every one correct his neighbor, for...if we do not do this, the crimes of each 5 pe will bring some general and intolerable damage to the city.

The final dynamic aspect of the Church's character in crisis was Her ability to overcome trials by modeling an unconquerable faith. The tragic circumstances provided an opportunity for church members to demonstrate the superiority of their religion by demonstrating a spirit of nobility, perserverance, and calmness in the face of hardship. On one occasion, the pagan prefect had to enter the church and still the terrified crowd. John leveled a blast of guilt producing rhetoric against his audience for their poor behavior in front of the ungodly outsider. The prefect should have left their gathering with the realization of "now great a difference there is between Gentiles [pagans] and Christlans. 53

John dramatically stressed the importance of each individual's response to the calamity. With God's help, one person could make a tremendous impact on the entire city. In John's words:

Thus shall we rid ourselves of all these sorrows; and although ten only among us should succeed, the ten would quickly become twenty; the twenty fifty; the fifty a hundred; the hundred a thousand; the thousand all the city. And just as when ten lamps are lighted, one may easily fill the whole house with light, so also with respect to right actions; should only ten act rightly, we shall light up a general flame fhroughout the city, to shine forth, and to procure us safety.

Once the crisis had been peacefully resolved, John was able to bring his evangelistic drama to a fitting climax. The Emperor's forgiving attitude was but another proof supporting John's fantasy theme. God had accomplished his purpose through his people, the church. A new chapter of faithfulness had been added to the splendid 
record of Antioch's Christian heritage. The spreading power of the church was visible in all of society, not only on the streets of Antioch, but in the imperial chambers as well. John concluded:

Heavens! how great is the power of Christianity, that it restrains and bridles a man who has no equal upon the earth; a sovereign, powerful enough to destroy and devastate all things; and teaches him to practice such philosophy as one in a private station had not been likely to display! Great indeed must be the God of the Christians, who makes angels our of men, and rendegs them superior to all the constraining force of our nature!

By means of this fantasy theme, John was able to present a clear and forceful vision to his congregation. He answered their identity question: "Who are we?" on both a personal and corporate level. His rhetoric provided a means of discerning who was inside and who was outside of the church family. He also clarified what was expected of the convert and heralded a unifying message to a fragmented church. The church at Antioch had been torn by years of divisive debate and various personality clashes. John's dramatization of the church's role in society must have been extremely appealing to his audience. The pressure of the crisis drew the Christian community together and provided a perfect context for reassessing the church's priorities.

\section{summary}

In this section of the chapter I have described the various fantasy themes that together comprised the rhetorical vision of John Chrysostom. I have isolated the themes in order to clearly identify the characterisitics of each one. In his homilies, John fused these five themes together into an integrated whole. 
John continually made use of polarized terms in communicating his message. In his supernatural drama, God and the devil were in opposition to each other. John's transformational drama contrasted the miraculous divine benefits that could be enjoyed in spite of the insidious strategies of the evil enemy. The judgment motif pitted an imperfect earthly judge against an equitable heavenly judge. Dichotomies of the $\mathrm{r} 1 \mathrm{ch} / \mathrm{poor}$ and the weak/strong, characterlzed John's social drama. His evangelistic drama was built around the differences between "Us" and "Them." His either-or rhetoric was forceful. John's fantasy theme scripts were vivid, creating and sustaining a clear subcultural sense of identity for Christians living through a time of crisis in fourth century Antioch. Appendix chart 1 provides an overview of John's fantasy themes.

Fantasy theme analysis is a valuable methodological tool in understanding the unique dynamics of John's rhetoric. However, It is now appropriate to shift our focus from description to a critical evaluation of his rhetorical vision. 


\section{CRITICAL EVALUATION}

Bormann describes the task of the rhetorical critic as follows:

Rhetorical criticism involves more than descriptions of discourse and the background, emergence, growth and decline of public consciousnesses. Once the rhetorical critics document the presence of rhetorical visions, communities, and consciousness, they can make a humanistic evaluation of the quality of the rhetoric and the social realities of the people who share the consciousness. A critic needs to evaluate and 58 judge the discourse and to provide insight into how it works.

In the first part of this chapter we have documented the presence of a clear rhetorical vision in the homilies of John Chrysostom. In this section we are concerned with questions regarding the quality, effectiveness, and appropriateness of his communicative response to crisis. We attempt to answer these questions by examining the possible strengths and weaknesses of John's rhetoric.

\section{strengths}

Writing some fifty years after John's death, the ecclesiastical historian, Sozomen, penned the following words in describing the rhetorical skill of the fourth century preacher:

There was...at Antioch on the Orontes, a certain presbyter named John, a man of noble birth and of exemplary life, and possessed of such wonderful powers of eloguence and persuasion that he was declared by the sophist, Libanius the Syrian, to surpass all the orators of the age.... Many of those who heard the discourses of John in the church were thereby excited to the love of virtue and to the reception of his own religious sentiments. For by living a divine life he imparted zeal from his own virtues to his hearers. He produced convictions similar to his own, because he did not enforce them by rhetorical art and strength, but expounded the sacred books with truth and sincerity.... He devoted himself to a prudent course of life and to a severe public career, while h $\$ 7^{a l s o}$ used a clear diction, united with brillance in speech. 
Such sentiment was expressed by many of John's contemporaries within the church. Sozomen's observation that John did not enforce his arguments with "rhetorical art" was certainly intended as a compliment, however, he falled to be objective in drawing such a conclusion. By the rhetorical standards of the fourth century John was a verbal artist and his homilies, on The statues, are indicative of the type of rhetoric for which he became famous. According to Schaff, John was the greatest puplit orator of both the Greek and Latin branches of the Church and an excellent model for preachers in large clties. ${ }^{58}$ My purpose in this section is to seek to evaluate some of the reasons for that rhetorical effectiveness. The following three roles, assumed by John in response to the Antiochene crisis, provide a helpful framework for assessing his strengths as a communicator: 1) John as an effective commentator, 2) John as an effective interpreter and 4) John as an effective rhetorician.

Effective Commentator. Throughout the crisis John regularly reported to his audience the latest information concerning the state of affairs in Antioch. Coming to the church to hear John speak was roughly a fourth century equivalent to turning on the radio or television to listen to the nightly news. The residents of Antioch were in a state of panic with various rumors of impending destruction circulating among the populace. In the midst of all the confusion, John attempted to obtain the latest facts and communicated them to his troubled congregation. By disseminating information and challenging false rumors, John deliberately tried to calm the crowds. It is obvious that he embellished the details and used material for his own 
rhetorical purposes; however, he still communicated information that was needed by his audience. Drawing on his unique access to the court and ecclesiastical news sources, John presented an optimistic view of the crisis. As a stablizing force, he encouraged his listeners to be patient and remain in Antioch, rather than to flee the city in fear. By combining the latest news with his rhetorical appeals, John kept his congregation informed and also attracted outsiders who were anxious to learn what the priest had to say about the crisis.

Effective Interpreter. In our discussion of John's fantasy themes, I have considered in detail the way in which John sought to interpret the events of the crisis to his audience. Whether one agrees with the content of John's dramatized crisis scripts or not, it is clear that he did provide a coherent view of "reality" for his listeners. Certainly one strength of his rhetorical vision was his ability to present simple and persuasive answers to complex questions about life, death, injustice, and values. John systematically employed themes that were familiar to his audience as he explained the seemingly unexplainable circumstances of the tragedy that had paralyzed the city.

John sought to convince his congregation that the crisis was not just the result of political frustration over the raising of taxes. The overturning of the statues of the Emperor was not Just a random accidental outburst of mob violence. They were not just spectators observing an historical event, they were witnesses of a divine drama. Furthermore, he portrayed the frightened and economically depressed of his congregation as special and valuable persons who were able to play 
a far more important role in influenclng the outcome of the crisis than the rich and prestigious leaders of the city.

John's interpretation of the crisis was comprehensive and provided his audience with a clear sense of ldentity and purpose for living through difficult days of unrest. There is, of course, another side to John's rhetorical explanations which I will consider in the section on weaknesses. My purpose at this point is only to emphasize that his forcefully articulated rhetorical vision grew out of both the belief systems and the pyschological needs of his listeners and was an important factor in his success as a communicator.

Effective Rhetorician. In evaluating John's communication skills, the fifth century ecclesiastical historian, Sozomen, objected to the idea that the priest might have utilized the devices of "rhetorical art" in persuading his audience to embrace spiritual truths. He preferred to think of the preacher as one free from the polluting stains of secular rhetorical thought and practice. ${ }^{59}$ that Sozomen failed to see, or perhaps refused to see, was that secular rhetorical theory had begun to strongly influence preaching in the fourth century. John's homilies clearly reflected this subtle change in the nature of Christian preaching. Hubbell describes this transformation of the sermon as follows:

The form of the Christian sermon varied, and was the product of many streams of influence. The most important point of contact with pagan literature was in the diatribe, the instrument of the Cynic, preaching virtue on the street corner, who was the closest approach in purely pagan society to the Christian preacher. The influence of this $k$ ind of address is evident in homiletic literature in the second and third centuries. This was a tendency inherited from the philosopher rather than from the rhetorician. But in the 
fourth century the great preachers began to conform more or less closely to certaig types well known in the oratorical literature of the day.

John's preaching was characterized by a combination of his fervent spiritual message with the fine rhetorical skills he had learned under his secular instructor, Libanius. His ability to weld together rhetorical vision and rhetorical technique certainly increased his impact upon a fourth century audience that was beginning to expect, and even demand, great oratorical performances from their pastors. We will examine John's strengths as a rhetorician by applying the classical rhetorical devices of invention, arrangement, style, and delivery to his homilies.

Invention, writes Wilken, "was a technique of discovery, a device to prompt the memory and stimulate the imagination." 61 Three modes of proof were used in constructing the persuasive argument: 1) ethos appeals focused on the character and credibility of the speaker, 2) logos appeals were based on reasoning skills, and 3) pathos appeals were centered on the listener's emotions.

Invention--Ethos: As I have previously mentioned, John's credibility before the Antiochene audience was greatly enhanced by his experiences as a desert monk. The rigid ascetic lifestyle of the wilderness had nearly cost John his life. The physical effects of that spiritual ordeal marked John as a true athlete of chrlst. To the Antiochene Christians, his active self-denying falth had earned for him the right to speak. John reinforced this nonverbal ethos factor by his verbal communication. Then he called his congregation to embrace the rigors of the Lenten fast, they were well aware that he 
had certainly practiced what he was preaching. Then he illustrated his themes with Biblical characters who had undergone extreme suffering, they were visibly reminded, by their priest's emaciated appearance, that he too had voluntarily experienced pain in demonstrating his faith.

John also affirmed the credibility of the priesthood by lavishly pralsing the actions of Bishop Flavian. The following quotation is an excellent example of how he not only elevated the status of his associate bishop, but also reaffirmed his own character and motivation.

He [Bishop Flavian] has disregarded, however, the ties of kindred, of old age, of infirmity, and the severity of the season, and the toils of the journey; and preferring you and your safety above all things, he has broken through all these restraints. And, even as a youth, the aged man in now hastening along, borne upon the wings of zeal! For if Christ gave Himself for us, what excuse or pardon should we deserve, having undertaken the charge of so numerous a people, If we were not ready to do and to suffer anything for the security of those committed Into our hands...much less doth it become us, who preside over those, who are not irrational, but spiritual sheep; who are about to give an account of this charge, not to man, but to God, to be slack in any respect, or shrink from anything which might benefit the flock...so it behoves us $6 \frac{5}{2}$ manifest a greater and more intense anxiety and diligence.

John effectively used such statements to underscore his authorlty as their spiritual guardian. Through both his actions and his words, he declared to the audience that he was of noble character and that he had only their best interests at heart. If they listened to him and followed his counsel, they would most assuredly be saved from the dangers of the crisis.

Invention--Logos: Chrysostom constantly based his arguments and appeals upon examples drawn from the Biblical record. The suffering 
Job, the three children of Israel in the fiery furnace, and numerous other Biblical characters were held up as prime models of patient trust in the face of adversity. John expressed the logic behind his illustrations when he said:

I have not referred to this history without a reason, but that ye may learn whether it be the wrath of a $k i n g$, or the violence of soldiers, or the envy of enemies, or captivity, or destitution, or fire, or furnace, or ten thousand terrors, nothing will avail to put to shame or terrify a righteous man. ${ }^{63}$

A few examples will give the reader a clear picture of the kind of proofs John employed in his rhetoric. Using his favorite subject, Job, he appealed to his audience to thankfully endure unjust suffering with the words:

The blessed Job is proof of this, who received so many intolerable wounds through the devil's plotting against him uselessly, vainly, and without cause. Yet, nevertheless, because he bore them courageously, and gave thanks to God 64 who permitted them, he was invested with a perfect crown.

John used the old Testament story of the fiery furnace in challenging his parishioners to remain in the city rather than fleeing to the Imagined safety of the desert. He reasoned:

Let us not entrust our safety to flight, but flee from sins, and depart our evil way.... Let us again call to mind those three children, who were in the midst of the furnace, yet suffered no evil, and those who cast them into it, how they that sat around were all consumed. What is more wonderful than this? The fire freed those whom it held possession of, and violently seized those whom it did not hold, to teach thee, that not the hapitation, but the habit of life, bringeth safety or punishment.

John was certain that the Bible provided ample proof to support his assertion that nothing disastrous could happen to Antioch if the citizens would just repent. The account of Jonah and the anclent clty 
of Nineveh provided all the evidence John needed. John asked his rhetorical question:

For He [God] threatened the city of Nineveh, and said, 'There are yet three days, and Nineveh shall be overthrown.' What then, I ask, was Nineveh overthrown? Was the city destroyed? Nay, quite the contrary; it both arose, and became still more distinguished... and we all still celebrate and admire it even to this day. For from that time it hath been a sort of excellent haven for all who have sinned, not suffering them to sink into desperation, but calling all to repentance; and by what it did, and by what it obtained of God's favour, persuading men never to despair of their salvation, but exhibiting the best life they can, and setting before them a good hope, $t g$ be confident of the issue as destined to be favourable.

John also used the Biblical drama of the Jewish Queen Esther to substantiate his belief that the crisis would be resolved by the effective appeal of Bishop Flavian. John developed his argument:

There was a certain Hebrew woman, Esther was her name. This Esther rescued the whole people of the Jews, when they were about to be delivered over to destruction. For when the Persian king gave the orders that all the Jews should be utterly destroyed, and there was no one who was able to stand in the way of his wrath,--this woman supplicated the merciful God to go with her to the king; and offering up her prayer to Him, these were the words she uttered, ' $O$ Lord make my words acceptable, and put eloquent speech in my mouth.' Let this be the prayer which we offer to God for our Teacher [Bishop Flavian]. For if a woman, supplicating on behalf of the Jews, prevailed to allay the wrath of a barbarian, much rather will our Teacher, entreating on behalf of so great a city, and in conjunction with so great a churgh, be able to persuade this most mild and merciful Emperor.

These examples clearly demonstrate how Chrysostom reasoned with his audience. The Bible was John's a'thority. From his perspective he could use greater proofs than those contained in that book. His audience also accepted the validity of the Biblical record, making his arguments appropriate for the context in which he spoke.

Invention-Pathos: John stressed the character development of 
his listeners and his rhetorlc strongly appealed to their splritual sensitivities and emotions. As Demosthenes and Cicero had confronted the apathy of their audiences, John repeatedly confronted the "listlessness" of his congregation. The goal of his rhetoric was to redirect their attention from the natural fears surrounding the crisis to a deep spiritual "fear" of God. For John, the terror of the Lord far surpassed any posslble terror they might experience at the hands of the Emperor. His effectiveness as a rhetorician was obviously enhanced by his ability to play on the emotions of his audience. We know that his listeners cheered his rhetorical skill. They must have also been deeply moved by his appeals to repentance and reformed behavior. The appropriateness of these "pathos" appeals will be addressed later in this chapter. One example will be sufficlent to demonstrate the nature and forcefulness of his rhetoric of fear:

If the dread of future punishment remained in the soul, that would overshadow all human fear.... For he who is always afraid of hell, will never fall into the fire of hell; being made sober by this continual fear...this is a childish terror of ours, if we fear death, but are not fearful of sin. Little children too are afrald of masks, but they fear not the fire. on the contrary, if they are carried by accident near a lighted candle, they stretch out the hand without any concern towards the candle and the flame; yet a mask which is so utterly contemptible terrifies them; whereas they have no dread of fire, which is really a thing to be afraid of. Just so we too have a fear of death, which is a mask that might well be despised; but have no fear of sin which is ffuly dreadful; and even as fire, devours the consclence.

John developed his persuasive arguments by skillfully using the three modes of proof I have presented above. He chose appeals that were familiar to his audience and that had powerful meaning within the context of his rhetorical community. Furthermore, John selected 
supporting material that paralleled the circumstances of the crisis. His Biblical characters had all endured their own crises and had triumphed. The trauma of the crisis also provided a clear opportunity for him to embellish his arguments with emotionally ladden calls to action.

Arrangement: At first glance, John's homilies seem to lack any clear organizational pattern. One is inclined to agree with Young's observation, "For the modern reader, the most disturbing aspect of Chrysostom's sermons is their chaotic form." 69 John did not prepare his homilies as written treatises, but delivered them extemporaneously. After closer study, however, a structural pattern becomes more apparent. The sermons roughly divide into three main parts; an introduction, an exposition of a Biblical text or character, and a conclusion which is always framed in the form of an exhortation to better living. 70

of special interest to this study is where John chose to place material that specifically related to the crisis in Antioch. This writer believes that John's rhetorical arrangement was not haphazard, but rather significantly effected his ability to successfully influence his audience. In looking at the homilies as a whole, it seems as if John scattered his focused references to the calamity throughout the various parts of his sermons. Upon closer investigation a different pattern emerges. John tended to concentrate his strongest crisis rhetoric at either the very beginning or the very end of his homily. From the perspective of the audience John's strategy must have greatly increased their retention of his themes. 
A powerful example of this effect can be seen in John's first homily which was preached just days before the riot. This was the longest of John's sermons in the series. For the most part, John's lengthy discussion of suffering and his exhaustive treatment of the Biblical text, "Drink a little wine for thy stomach's sake," must have been somewhat difficult for the audience to fully assimilate. The one thing that they did probably take with them, as they exited the church, was John's final admonition, which had little to do with the rest of the homily. That final appeal was John's request that the Christians of Antioch take it upon themselves to cleanse the city of all those "blasphemers" who were an "insult to God." 71 As "savlours of the city" John Implored them to do whatever was necessary, even if that meant attacking those who were guilty of such "common crimes," in order to fulfill their God-given destiny. ${ }^{72}$ John's rousing call to action, placed as it was at the very end of the sermon, was what his audience remembered. That aggressive appeal, as we have suggested elsewhere, may have also played a crucial role in precipitating the very crisis John hoped to avold. This approach to rhetorical arrangement was also employed in other homilies.

John's other technique was to open his homily with a direct reference to the state of affairs in Antioch. Arresting the audience's attention with poignant descriptions of the crisis, John exhorted his listeners to respond. Much of the rest of the sermon was rather anticlimactic. John had made his point and his audience would not likely forget it. The following example highlights this effect:

There is a silence blg with horror, and loneliness everywhere; and that dear hum of the multitude is stlfled; and even as 
though all were gone beneath the earth, so speechlessness hath now taken possession of the city; and all men seem like stones, and being oppressed by the calamity like a gag on their tongues; they maintain the profoundest silence, yea, such a silence as if enemies had come on them, and had consumed them all at once by fire and sword!...But afford me your attention! Lend me your ears awhile! Shake off this despondency!...For should the Lord see that His words are listened to carefully; and that our love of divine wisdom stand the trial of the difflculty of these times, He will quickly take us up again, and $7 y^{1} 11$ make out of the present tempest a calm and happy change.

From a rhetorical perspectlve these patterns of arrangement are certainly significant. This strategy of emphasis must have contributed to John's effectiveness in moving his audience to action. Both his knowledge of rhetorical theory and his skill in rhetorical practice were also reflected in his organizational plan.

Style: Although John protested that it was not his purpose to "exhibit powers of oratory, ${ }^{74}$ he clearly made use of the standard rhetorical tools of the sophists of hls day. He recognized the need to vary his style in order to appeal to the wldest audlence. John described his various stylistic options in comparing his role to that of one caring for the sick:

We must not set before them a meal prepared haphazardly, but a varlety of dishes so that the patient may choose what sults his taste. We should proceed in the same way in spiritual banquets. Since we are weak the sermon must be varied and embellished; it must contain comparisons, elaborations, digressions, $75^{\text {nd }}$ the like so that we may select what will profit our soul.

The rhetors of the fourth century made eloquent use of hyperbole. John was no exception. He frequently used exaggerated speech to magnify the issues at hand. For example, a simple report concerning the Blshop's trip to intercede before the Emperor was expanded and ornately rephrased as follows: 
When I look on that throne, deserted and bereft of our teacher, I rejoice and weep at the same time. I weep, because I see not our father with us! but I rejoice that he hath set out on a journey for our preservation; that he is gone to snatch so great a multitude from the wrath of the Emperor! Here is both an ornament to you, and a crown to him! An ornament to you, that such a father hath been alotted to you; a crowp to him, because he is so affectionate towards his children.

Vilken is correct when he says that such passages are "not lonely flights of rhetorical enthusiasm sprinkled here and there throughout his sermons; they are the very stuff of his preaching." 77 John's audiences expected and loved just such oratorical display.

Extensive metaphors and simlles also characterized the rhetoric of the fourth century. Certain stock metaphors were memorized and repeatedly used in various contexts. 78 John often began his homilles with a lengthy metaphor. One of his favorites was drawn from the medical world:

For if in the case of bodily wounds, physicians do not give over their fomentations, until they perceive that the pain has subsided, much less ought this to be done in regard to the soul. Despondency is a sore of the soul, and we 7 gust therefore foment it continually with soothing words.

John effectively used metaphors and comparisons drawn from the athletic arena, the sea, military science, and nature. His carefully drawn word pictures added clarity and forcefulness to his communication. Such compounded verbage is unnatural to modern ears, but John's audiences clapped for more.

In addition to these major stylistic devices, the fourth century communicator had a vast arsenal of figures of speech at his disposal. These various verbal aids were mastered in school and were carefully and appropriately employed according to established rules of 
rhetorical etiquette. Wilken describes a few of the vast number of technical verbal resources available to, and used by, the skillful preacher:

John uses figures for dramatic effect, such as asyndeton, omission of connectives, and polysyndeton, accumulation of connectives. He employs figures of sound: paronomasiaa, similarity of sound with dissimilarity of sense, and parachesis, two words of different roots but with similar sound....His sermons use diaporesis, pretended doubt: 'How shall I begin this speech?' or employing paraleipsis, he pretends to pass over a point in sllence, while emphasizing that very point. He raises questions and provides answers, giving the semblance of dialogue. He raises offectlons to his argument only to refute them in the next line.

With these techniques the rhetorician was prepared to respond in any speaking context. The same expressions or figures could be varlously applied and used to censure or to praise. Phrases that John's former secular teacher, Libanius, had employed in praise of pagan accomplishments, were utilized by John to pralse Libanius' Christian opponents. In this regard, John was modeling the typical ethical standards of the rhetoric of the fourth century. ${ }^{81}$ As wilken concludes, "the rhetor was less interested in the veracity of his language, whether it conformed to some objective standard of truth, than he was in the effect his words would have on his hearers." 82 John's flalr for the dramatic was especially evident in his homilies, on The statues. Our earlier discussion of John's fantasy themes has carefully documented John'; rhetorical strategy in this regard. On a number of occasions he created lengthy dramatic narratives in which he verbally portrayed for his audience supposed dialogues between Bishop Flavian and Emperor Theodoslus. The concluding sermon in his series was, almost in its entirety, a 
carefully constructed script of the Bishop's successful appeal to the Emperor. John's intent was certainly not to provide an accurate historical record of their conversation. By means of his rhetorical skill he made the event seem larger than life. The audience would be unable to soon forget the courage and wisdom of their spiritual father, Flavian. Thus, John was able to secure the cheers of the crowd and also accomplish his rhetorical goals. The following lines from John's creative dialogue clearly reflect his dual purpose (Bishop Flavian is speaking):

But at the present time I have come not from these only, but rather from one who is common Lord of angels and men, to address these words to your most merciful and most gentle soul. 'If ye forgive men their debts, your heavenly Pather will forgive you your trespasses.' Remember then that Day when we shall all give an account of our actions! Consider that if you have sinned in any respect, you will be able to wipe away all offences by this sentence and by this determination, and that without difficulty and without toil. Some when they go on an embassy, bring gold, and silver, and other gifts of that kind. But I am come into your royal presence with the sacred laws; and instead of all other gifts, I present these; and I exhort you to imitate your Lord, who whilst He is daily insulted by us, unceasingly minlsters His blessings to 811 ! and do not confound our hopes, nor defeat our promises.

John's exuberant and forceful style contributed to his success

as a fourth century rhetor-preacher. Young writes the following

evaluation of Chrysostom's style:

If his style and methods of sermon construction fail to appeal to our taste, they were neverthless the most effective method of communication in his time.... His brilllant use of sophistical conventions wh flexibllity and originality is hardly matched elsewhere.

Delivery: John was described by his contemporarles as short in stature, very thin, with a large bald head with a broad lofty 
forehead, deep-set piercing eyes, with a searching look, and an expressive mouth. ${ }^{85}$ standing in the center of the church he was only a few feet above and only inches away from the audience. John preached extemporaneously, there was no manuscript to inhibit his contact with the congregation. They could easily see his facial expressions and observe his every gesture. John seldom disappointed them. Although we have printed records of his homilles, it must be remembered that John prepared his rhetoric for oral delivery. He thrived in the pulpit. John wrote, "Preaching makes me well....As soon as I open my mouth, all weariness is gone; as soon as I begin to talk, all fatigue is over....For just as you are hungry to hear, so am I hungry to preach. ${ }^{86}$

The epithet given him, "of the golden mouth," was descriptive of his fluent style of delivery, both in tone and expession. A contemporary compared his fluency to the inexhaustible flow of the Nile River ${ }^{87}$ John's command of the Greek language, his rhythmic flow of speech, dramatic vividness, and his intense earnestness to communicate were keenly appreciated by his audience.

In this section I have sought to explain John's effectiveness as a communicator in crisis by discussing his strengths as a commentator, interpreter, and rhetorician. John not only successfully relayed important information to his audience about historical events, he provided a completely new "social reality" for his listeners. He accomplished his goal by skillfully employing a vast variety of fourth century rhetorical devices. 


\section{Weaknesses}

My purpose in this section is to critically explore the other side of the issue concerning John's rhetorical effectiveness. It is not my intent to judge whether his rhetoric was excessively ornate and flowery, for I have already determined that he reflected the patterns and techniques of a time when great oratory was evaluated by a different standard than might be used today. Instead, my focus will be to investigate the question of whether John's rhetorical vision was consistent and appropriate in light of his own stated value system and beliefs. This is a difficult task because it is extremely hard to determine in some cases whether John intended his words to be taken literally, or if he was only indulging himself in the extravagances of fourth century rhetoric. Recognizing this potential danger I will examine apparent weaknesses in two categories: 1) internal contradictions in John's rhetorical vision and 2 ) divisiveness as a result of his rhetoric.

Internal contradictions. A careful analysis reveals a number of striking inconsistencies in John's rhetorlcal vision. The most obvious contradiction involved John's own view of crisis. He repeatedly stated his hopes and prayers that the tragic calamity might be brought to a speedy and peaceful end. His stated purpose was to provide comfort and encouragement for those overcome by fear and depression. Yet, at the same time, his rhetorical appeals rested upon a continued state of uncertainty and terror. If the city needed John to help them through the crisis, it might also be equally asserted that John needed the crisis to give impetus to his arguments. In fact 
his worst fear was that when the crisis was over, the people would drift back to their old patterns of behavior. The urgency of the moment sustained the sense of drama John had created in his fantasy themes. This is reflected in the selected homilies chosen for this study. John's rhetorical expression reached its zenith when the turmoil of Antioch was at it apex. Those sermons that were delivered during lulls in the crisis tended to lack the same kind of intensity. This ambivalence was reflected in John's response after the crisis was peacefully resolved. Rather than putting the turmoil behind them, John urged his listeners to constantly keep alive the memory of that painful time. God was to be praised for permitting the crisis as well as providing deliverance. ${ }^{88}$

A second major contradiction can be observed in the way John used strong emotional appeals to stimulate his audience's sense of guilt and need for repentance. In John's vision the very crisis was evidence of God's punishment of evil. Suffering was portrayed as a visible consequence of sin. In other contexts, John commended those who had endured suffering at the hands of Satan. The audience was left to interpret their own experiences of pain and suffering. Was it a curse from God, meaning they should repent? Or was it a time of testing from Satan, to be patiently endured? The potential guilt resulting from such cause and effect reasoning could be intense. John believed in divine grace and forgiveness and was confident that the Emperor would mirror those same qualities to the citizens of Antioch; however, rhetorically he seemed to place far more emphasis on cataloging sin. His fantasy themes presented an impossible goal of 
human perfection for his 1 isteners. Any progress they made in following their priest's counsel was rewarded with even more stringent demands. By placing before his audience such unattainable ideals, John could both accent their failures and sustain his dramatic appeal for reformation. One might consider this a rhetorical version of the carrot on a string suspended before the horse. John held out the carrot of promised forgiveness in order to move persons toward change, but he never let them taste it.

John fostered a third inconsistency in promoting his view of the church as an instrument of social change. He clearly proclaimed that he saw Christians as the "saviours of the city." 89 They were to represent the person of Christ to their fellow pagan neighbors. For John, the task required a mllitant church that was not afraid to correct wrongdoers. Aggressive evangelism for John implied the acceptability of using violence if the goal was holy. John introduced the possibility of a new type of martyrdom when he said, "contend, even to the death, for the truth, and God will fight for thee." 90 John may not have been the first to develop such a theme, he certainly was not the last. Yet, the stark contradiction of his terms was so blatantly portrayed: saviours who fulfilled their destiny by violence done to others, rather than saviours who laid down their lives in sacrificial love for others. It is difficult to discern the roots of John's theological aberration. The church was enjoying a new sense of power in the fourth century. Perhaps it was partially a reaction to the church's history; the persecuted now became the persecuters. WIth a Christian emperor on the throne John may have envisioned a glorlous 
new era, a Christian Empire on earth. More likely it was symptomatic of his zeal for the faith and his conviction that the end did justify the means.

Closely aligned with the contradictory message above, was John's use of abusive rhetoric. He was quick to label those outside the church as "perverse and dissolute." 91 John seemed to find a special joy in exposing the cowardice of the secularist leaders of the community. He described them as, "more abject in disposition than the dogs under the table... who do everything for the sake of the belly. ${ }^{92}$ What makes his use of invective so fascinating is that John invested considerable rhetorical energy, especially in his homilies, on The Statues, in soundly castigating the practice of slander. This seems, at least on the surface, as a classic example of failing to practice what one preaches. The issue is somewhat clouded by the fourth century sophistic use of the invective, or psogos. Wilken describes this denigrating technique:

In the invective, the rhetor deliberately twisted the material to distort, to falsify, to condemn.... In a psogos, the rhetor used omission to hide the subject's good traits or amplification to exaggerate his worst features, and the cardina ${ }_{3}$ rule was never to say anything positive about the subject.

The fifth century church historian, Socrates, viewed the use of such language as a standard element in the rhetorician's bag of verbal tricks. Socrates and John apparently saw no moral or ethical dilemma in the Christian condemning slander and falsehood on the one side, while spewing forth vindictive half-truths or lies on the other. According to Socrates: 
For everyone who enters into controversy with another, sometimes trying to pervert the truth, and at others to conceal it, falsifies by every possible means the position of his antagonist. And an adversary is not satisfled with doing malignant acts against one with whom he is at variance, but will speak against him also, and charge upon the object of 94 his dislike the very faults he is conscious of in himself.

Interestingly, this same historian, socrates, critically evaluated the rhetoric of Chrysostom with the words, "the liberty of speech he allowed himself was offensive to very many." 95 Perhaps John's tirades against slander were disguised manifestations of his own weakness. It has always been easier to fixate on the speck in a brother's eye while ignoring the $\log$ in one's own.

A final contradiction of belief and practice focuses on John's possible prioritizing of rhetorical impact above the presentation of truth. Wilken writes that fourth century communicators "appear more interested in the effect their speeches had on their audience, in how things sounded and how people responded, than in the truth of what they said." 96 It is difficult to establish if John deliberately distorted information in his homilies, on The statues. He obviously stretched the truth in creating his dramatic scripts. By masterfully mixing fact and fiction with a little imagination he produced fantasy themes complete with heroes and villains. We do know from Libanius's parallel account of the crisis that John did slant the facts to some extent. From John's point of view, the Christians were clearly responsible for guiding the city through the crisis. The pagan leaders were negatively portrayed as all fleeing the city in panic. In contrast, Libanius maintained that the city was saved because of the dlligent action of pagans like himself. The truth probably rested 
somewhere between the two. John was sllent about the political efforts of Libanius because such information would weaken his rhetorical argument about the superiority of the christian faith. Likewise, Libanius was mute about the preaching of John, the mission of Flavian, and the intervention of the monks, because he, also, was only interested in conveying his rhetorical agenda and defending paganism. In another of his works, John provided his own justification for magnifying or even altering the truth:

For that man would fairly deserve to be called a deceiver who made an unrighteous use of the practice, not one who did so with a salutary purpose. And often it is necessary to deceive, and to do the greatest benefits by means of this device, whereas he who has gone by a straight course has done great mischief to the person whome he has not deceived. 97

The five contradictions I have discussed above give the reader another glimpse of Chrysostom, a look that is needed if one is to develop an accurate and balanced view of the ancient "golden-mouthed" orator.

Divisiveness. One very visible characteristic of John's rhetoric, discussed in the section on fantasy themes, was his frequent use of dichotomies. He not only painted reality in black and white colors, he also placed persons in separate and distinct categories. The rich and the poor, pagan and Christian, Jew and Gentile, male and female, zealous and listless, sinners and saints, and the good and bad were all easily identifiable in John's fantasy themes. Correspondingly, John censured and praised the various social groups he had polarized for his audience. such rhetoric must, to some extent, have served to further alienate people as it nurtured misunderstanding and fostered extreme prejudice. It ma have also led 
to hostility and violence. The riot in Antioch at least suggests that possibility. By identifying the enemy and sending his troops out to attack the troublemakers, John was at the least adding fuel to an already volatile situation. Wilken evaluates John's use of abusive and divisive rhetoric and concludes:

The ancients, however, were not embarassed by name calling and obloguy. They seem to have thrived on it, and by providing new occasions for rhetorical display, the religious conflicts of this period revived the art of rhetoric and breathed new life into stale and musty language. The rhetors now had real, not imagined, foes. Yet the asperity, the hostility and enmity, the capacity to hate still give us pause. For surely something of this charged and emotive language must have passed over into the attitudes of people toward one another and their relations with each other. One would think that such language would incite passiong $g_{8}$ and lead an angry crowd to storm the homes of one's enemies.

Such occurences rarely happened in the fourth century, however, Antioch may have been one of the exceptions to the rule. Most likely John's rhetoric did not precipitate the actual riot. Looking at the other side, his first homily, delivered the week before the riot, certainly contained nothing to help heal the festering social unrest. In that regard, Chrysostom, missed a "golden" opportunity to attempt to unify an already polarized city through his eloquent rhetoric.

\section{SUMMARY}

In the second part of this chapter I have critically examined the strengths and weaknesses of John's rhetorical vision. John played a critical role before, during and after the events of the actual crisis. We have attempted to be both fair and critical in our survey of the materials. Wilken writes that, "every act of historical 
understanding is an act of empathy. ${ }^{99}$ an honest understanding of the forces of the fourth century is critical in appreciating the qualities and faults of John Chrysostom. By expanding our awareness of one who lived some 1600 years ago, we also gain insight into ourselves and the various strengths, weaknesses, and fantasy themes that comprise our own rhetorical visions. 
CHAPTER $V$ NOTES

1 Bormann, The Force of Fantasy 8 .

2 Bormann, 5.

3 Robert F. Bales, Interactive Process Analys is: A Method for the study of Small Groups (Cambridge, Mass.: Addison-We1ley, 1950) 152.

4 Bormann, "Fantasy and Rhetorical Vision: The Rhetorical Criticism of Social Reality," Quarterly Journal of Speech 58 (1972): $396-407$.

5 Chrysostom, II.10.

6 Chrysostom, XXI.8.

7 Chrysostom, XXI.9.

8 Chrysostom, XVII.3.

9 Chrysostom, II.1.

10 Bormann, The Force of Fantasy 8.

11 Chrysostom, I.18. Also see the Biblical book of Job, chapters 1,2 .

12 Chrysostom, II.1.

13 Job $2: 13$.

14 Chrysostom, II.1.

15 Chrysostom, XVI.2.

16 Bormann, Fantasy 8.

17 Bormann, 8

18 Bormann, "Fetching Good out of Ev1l" 134.

19 Chrysostom, V.19.

20 Chrysostom, VI. 14. 
21 chrysostom, III.19.

22 chrysostom, III.20.

23 Chrysostom, V.15.

24 Chrysostom, XV.16.

25 Chrysostom, III.17,18.

26 Chrysostom, III.21.

27 Chrysostom, XV. 3.

28 Chrysostom, XXI.1, 20.

29 chrysostom, XIII. 2.

30 Chrysostom, XIII.6.

31 Chrysostom, I. 20.

32 Chrysostom, I I.10.

33 Chrysostom, III.20.

34 Chrysostom, V.9.

35 Chyrsostom, I. 28.

36 chrysostom, XVII. 5.

37 Chrysostom, XIII.4. (Scripture references are from

Ecclesiastes $1: 2$, and Isaiah $43: 6,7$ )

38

Chrysostom, II.18.

39 Chrysostom, II. 27.

40 Chrysostom, II.17.

41 Chrysostom, II.17.

42 Chrysostom, XVII.10.

43 Chrysostom, XVII.10.

44 Chrysostom, XVII.12 (The Biblical reference is from Hebrews $11: 10$. 
45 Chrysostom, I. 32.

46 Chrysostom, III.4.

47 Chrysostom, 1.32.

48 Chrysostom, I.32.

49 Chrysostom, I. 33.

50 Chrysostom, II.10.

51 Chrysostom, VI.1.

52 Chrysostom, II.11, 12.

53 Chrysostom, XVI.7.

54 Chrysostom, VI.18.

55 Chrysostom, XXI.13.

56 Bormann, The Force of Fantasy 3,4 .

57 Sozomen, Ecclesiastical History VIII.2.

58 Schaff, Nicene and Post-Nicene Fathers $9: 22$.

59 Sozomen, VIII.2.

${ }^{60}$ Harry Hubbell, "Chrysostom and Rhetoric." Classical Philology 19 (July 1924): 263.

61 wilken, 98.

62 Chrysostom, III.1.

63 Chrysostom, IV.9.

64 Chrysostom, IV.9.

65 Chrysostom, VI.10.

66 Chrysostom, V.15.

67 Chrysostom, III.6.

68 Chrysostom, v.10,11.

69 Young, Erom Nicea to chalcedon 155. 
70 Burns, Saint John Chrysostom's Homilies on The Statues 117.

71 Chrysostom, I.32.

72 Chrysostom, I. 32 .

73 Chrysostom, II.6,9.

74 Chrysostom, I.2.

75 Chrysostom, Proph. obscur., I; 56.165 as quoted by wilken, 107.

76 Chrysostom, III.1.

77 wilken, 107.

78 wilken, 107.

79 Chrysostom, VI.1.

80 wilken, 111.

81 wilken, 112.

82 wilken, 112.

83 Chrysostom, XXI.17.

84 Young, 158-159

85 Currier, Nine Great Preachers p.42.

86 Chrysostom, Hom.post terrae, 50.713, quoted by Wilken, p. 106.

87 currier, 43.

88 Chrysostom, XXI.20.

89 Chrysostom, I. 32.

90 Chrysostom, I. 32.

91 Chrysostom, I.32.

92 Chrysostom, XVII.5.

93 wilken, 113. 
94 Socrates, III. 23.

95 socrates, VI.3.

96 wilken, 111.

97 Chrysostom, On The Priesthood I. 8

98 wilken, 122-123.

99 Wilken, 162. 


\section{CHAPTER VI}

JOHN CHRYSOSTOM: CONCLUSIONS ON HIS CRISIS RHETORIC

Throughout this study it has been my purpose to analyze the characteristics of the crisis rhetoric of John Chrysostom as reflected in his homilies, on The statues. To this end I have carefully examined John's background, the historical setting of his homilies and the specific rhetorical purposes that motivated him to speak. I have also identified and critically evaluated John's rhetorical vision by focusing attention upon the various themes he employed as he attempted to dramatize and interpret the events of the crlsis for his audience. In this concluding chapter, I summarize the results of my research, discuss some implications suggested by this study and present some proposals for further research.

SUMMARY

Biographical Summary of John's life

John was born in the important syrian city of Antioch circa A.D. 350. His cultural roots were grounded in both the Roman soil of his father and the Greek heritage of his mother. As a child, John enjoyed the special privileges of life among the well-educated upper class of Antioch. Most significant among these privileges was the opportunity to be exposed to the finest educational training of the time. John's rhetorical instruction began when he was enrolled in the 
school of the famous rhetorician, Libanius. Under his tutelage he studied the rhetorical curriculum of the Second Sophistic Period with its predominant emphasis upon artistic style and exuberant display of eloquence. From his secular professor John acquired the skills preparatory to an expected career in the legal profession or imperial service.

John was uncomfortable with the ethical practices of the courts and instead of pursuing a career in law or politics he chose to embrace Christianity, withdraw from society and assume the ascetic life style of a monk. John's life and rhetoric were deeply influenced by his monastic experiences. For over ten years he practiced a fanatical devotion to the ascetic principles of extreme self-denial and solitude. It was only after his health failed that he left the wilderness and returned to the city of Antioch.

Church leaders in Antioch recognized John's potentlal and he was given new responsibilities which eventually led to his ordination to the priesthood in A.D. 386. John devoted his energies to his new role as pastor, exercising the rhetorical techniques he had learned from the secularist, Libanius, in a sacred context. He had been in the pulpit of the Antiochene church about a year when the city was engulfed in political and social crisis. An imperial degree increasing taxes prompted an outbreak of mob violence. In their anger and frustration the crowds pulled down the revered statues of the Emperor Theodosius. It was during this time of unrest and anxiety that John preached his twenty-one homilies entitled on The statues. His decisive response to the situation in Antioch contributed 
significantly to his growing reputation as an effective and eloguent communicator. Political and religious leaders in the capital city of Constantinople also became aware of his rhetorical abilities and they appointed John to the position of bishop of that city in A.D. 398 . Following an initial perlod of mutual admiration between John, the religious hierarchy and the imperial family, relationships deterlorated rapidly. In his homilies John had severely criticised the behavior of his fellow clergy. He had also directed his rhetoric against the Empress Eudoxia. This conflict eventually resulted in his banishment from Constantinople in A.D. 404.

During his years of exile, John continued to influence the Christian community through his correspondence. Angered by his power, even at a distance, the Empress succeeded in having him moved to a more inhospitable location. John died while enroute to Pityus in A.D. 407.

John's career was marked equally by success and controversy. He could thrill the crowds with his words and they freguently applauded his accomplishments. Conversely, he was often outspoken and abusive and may have been responsible on more than one occasion for having incited the crowds to violence by his rhetoric.

\section{Summary of John's Rhetorical Imperatives}

In researching John's turbulent fourth century world, I identifled a number of political, social, economic, and religious factors that made it both possible and necessary for John to deliver his message to the Antiochene audience. The combination of these factors created a receptive climate for John's message. 
Politically, the Roman Empire was experiencing tremendous change. Early in the century, the Emperor Constantine had begun the process of merging the affairs of the state with those of the church. The Emperor Julian had reversed this trend about the time that John was an adolescent, studying rhetoric under the pro-Julian, Libanius. After Julian's death, the tide again turned in favor of the church. Theodosius, Emperor during the crisis of A.D. 387, solidified the new sacred-secular alliance, eventually passing legislation forbidding pagan ceremonies and sacrifices. Instead of preaching in a context where there was religious persecution of Christians, John spoke at a time when the clergy was enjoying considerable power and influence in political circles. The very building in which John preached had been commissioned by constantine. The state was encouraging pagans to accept the "faith" of the Empire. Consequently it was not surprising that the crowds flocked into John's church when the crisis engulfed Antioch. The church seemed to provide the best possibility for safety from the impending wrath of the Emperor. At the same time, John felt that it was important that he defend and commend the actions of his Christian Emperor. With great foy, he triumphantly proclaimed that the crisis was over and the city had been spared because thelr political leader had responded with Christian grace and mercy, rather than in destructive rage.

Socially and economically, the citizens of Antioch were divided into various classes with a large gulf separating the rich from the poor. All felt the weight of oppressive taxation. Throughout the Eastern part of the Empire, citizens grew increasingly frustrated with 
the financial demands placed upon them by their leaders. When Emperor Theodosius issued an edict calling for additional tax revenues in February of A.D. 387, members of Antioch's city council protested. What may have begun as a political demonstration to express dissatisfaction with the tax levy turned into a full-fledged $r$ iot. During the riot, the statues of the Emperor and his family were pulled down and dragged through the streets of Antloch. Such behavior constituted an act of open treason. The actual riot lasted only a few hours. However, once the citizens of Antioch realized what had taken place they began to panic. Fearful that the Emperor would destroy Antioch in his anger, many fled the city and hid in the wilderness. John's homilies, on The Statues, were his response to this significant crisis. John's church was packed with church members and outsiders who suddenly got "religious" in the context of uncertainty and distress. The crisis provided John with a unique opportunity and a captive audience. The riot was the immediate "imperative" that compelled him to try and calm the terrified crowds. The occasion also gave him a chance to vividly impress his audience with his spiritual agenda for the Christians of Antioch.

If one is to fully understand John's rhetorical context and the reasons he felt he had to communicate, one must also recognize the forces which were at work within the religious community of Antioch. The government, in legalizing Christlanity, had removed the threat of external persecution of the falthful. Free of this "enemy" the church began to direct its energy agalnst such groups as heretlcs, pagans and Jews. John's sermuns clearly reflected this trend. He identified 
for his audience who the new "enemies" were and he challenged his congregation to assume their role as purifying agents in society by correcting those who failed to embrace the standards of the faith.

The believers of Antioch periodically fragmented into a number of diverse camps. Sometimes they divided over theological differences, at other times they were split in their allegiance to different leaders. There was a definite need for someone who could foster a spirit of unity within the Christian community. In this sense, the crisis was especially valuable to John. The crisis brought the Christian community together. John seized the opportunity to further enhance the group's solidarity by stressing what he felt were the differences between those on the inside ("us") and those on the outside ("them").

It is also important to remember that Christian preaching in the fourth century was being strongly affected by the rhetorlcal theory and practice of the time. The pulpit became the stage for the performance of rhetorical art. The parishioners cheered their preachers much like the pagans had applauded their rhetors. We know that people were drawn to hear John preach because of his rhetorical reputation. John's style of rhetoric fit the expectations of his audience. They came, not only to be instructed, but to be entertained. John usually did not disappoint them.

The political, social, economic and religious factors described above provided John with a unique context and occasion for his homilies. These factors made it both possible and Imperative that he address the crisis-bound citizens of Antioch. 
Summary of John's Rhetorical Purposes

In this study I surveyed the settings of ten selected homilies from John's Lenten series, on The statues. The first homily in the serles was delivered the week before the actual rlot. The next eight homilles (II, III, V, VI, XIII, XV, XVI, XVII) that I investigated were communicated during the days and weeks of the crisis. John preached almost daily during this time while his listeners anxiously awaited some news regarding the Emperor's judgment in the matter of the sedition. The final homily ( XXI) examined was delivered after the crisis had been fully resolved. In exploring John's purpose in his first homily, I have emphaslzed in this study that he potentially may have helped to precipitate the riot by his invective against certain troublemakers in the city. He clearly instructed his followers that violent means were acceptable if the end was a worthy one. I have proposed the idea that such rhetoric may have been interpreted by his audience as a fustification for revolting against the unfair tax demands of the Emperor. The discontented citizens of the city needed little prompting to express their sense of frustration. While it is impossible to discern John's motives with complete accuracy, it seems at least possible, if not probable, that his fiery rhetoric may have contributed the small spark that was needed to ignite the emotions and actions of the mob.

Two clear rhetorical purposes are apparent in the homilles John proclaimed during the actual days and weeks of the crisis. First of all, recognizing the distress of his audience, he attempted to encourage his listeners to remain calm and not panic. In order to 
accomplish this goal John emphasized a message of hope and comfort. Using Biblical themes to support his assertions he assured them that all would turn out well. Their God and their faith would triumph over the events of the crisis. John's second objective was to exhort his audience to more virtuous living. He attacked their sinful behavior with zeal, condemned their spiritual apathy and blamed them for contributing to the crisis by their moral and spiritual failures. John addressed many issues of reform. His favorite topics centered, interestingly enough, on communication abuses such as slander and swearing.

John's rhetorical concerns did not end once the crisis was peacefully resolved. In his final homily, delivered on Easter Sunday, John led his congregation in celebration. With considerable rhetorical embellishment he reconstructed the dialogue that had taken place between the Emperor and Bishop Flavian. Flavian had journeyed to Constantinople, on behalf of the citizens of Antioch, in order to persuade Theodosius to forgive the Antiochenes for their acts of treason in destroying his statues. By means of his creative and vivid narrative, John reaffirmed his crisis themes. Only their continued reformation of character would prevent the city from being plunged into an even greater tragedy. Once the crisis was over, John did everything in his rhetorical power to make sure the spiritual implications of the tragedy remained clearly etched in the memories of his listeners. 
Summary of John's Rhetorical Vision

In studying John's crisis rhetoric I have made use of the terminology and critical framework of fantasy theme analysis proposed by Ernest Bormann. I have discovered, in my research, that John repeatedly dramatized certain rhetorical themes in his effort to interpret the meaning of the crisis to his audience. By utilizing examples, narratives, metaphors and theological concepts that were very familiar to his audience, John created a new "social reality" for the Christians of Antioch. Those who accepted John's rhetorical message "saw" the events from a new perspective. John provided his listeners with a whole cast of heroes and villians engaged in a divine plot. John also involved his parishioners in the spiritual play. They were not only spectators of a cosmic drama being acted out in the crisis of Antioch, they were participants who, by assuming their appropriate roles, could write their own ending to the story. I have identified five dominant dramatized themes that together comprised John's rhetorical vision of the crisis.

John's first concern was to recast the historical events of the crisis of the statues into a cosmic supernatural drama. In John's rhetorical vision, God and satan were engaged in a battle over the citizens of Antioch. The Christian forces, led by their bishop, priests and monks took on angelic proportions. The instigators of the rlot were costumed in demonic attlire and were representatives of Satan's desire to destroy Antloch. Through the use of this theme John sought to provide his audience with an answer to the basic question of "Who" was In charge of world events. According to John, Satan was 
able to work his schemes only because God had permitted him to do so. God would triumph through the patient perseverance of his people. This was John's central rhetorical theme. All of his other dramatized scripts of the crisis grew out of this major vision of reality. John directly involved his listeners through his second theme, which I identified as his transformational drama. John was certain that "if" the Christians of Antioch reformed their lives, they "then" would experience God's transformation of the evil of the crisis into ultimate good. For John, the transformation began with personal conversion and climaxed in a new society where Christian behavior and values would triumph over the wickedness of humanity. The positive outcome of the crisis was further proof to John that this had indeed happened in Antioch. The christians of the city had met the divine prescription for spiritual change. Conversion and spiritual reformation had resulted in divine dellverance from the crisis, just as John had promised. In this way, John provided his congregation with an answer to "Why" the crisis had taken place. They could find meaning in their suffering because God was accomplishing his good in their lives.

John utilized the legal aspects of the riot and the subsequent courtoom proceeding in Antioch to fashion a third spiritualized script which I labeled his judgment drama. The priest magnified the events of the crisis by introducing Christ as the perfect heavenly Judge who would execute perfect justice. In John's vision the danger was not what the Emperor or his representatives might do in exacting 
punishment upon the guilty of the city, but what God would do in judging persons worthy of heaven or deserving of hell. By means of this intense rhetorical vision of future reward and punishment, John was able to arouse strong emotions of hope, fear, and guilt.

As John surveyed the impact of the crisis upon Antioch's social structures, he found ample material for another portrayal of $h$ is vision of reality. In what I have called his social drama, John repeatedly emphasized the vanity of earthly fame, fortune, and power. The wealthy of Antioch were unable to buy forgiveness from the Emperor. The circumstances of the crisis proved the transient value of earthly riches. In contrast, John declared that the poor man who trusted in God was richer than all. No earthly crisis could threaten the ultimate security and destiny of that person. John's vision must have been quite appealing to the lower-class members of his audience. This dramatized reversal of poverty and wealth would give them something to cheer about in the midst of the crisis as well as something to hope for beyond it.

John was convinced that the church played the crucial role in social crises. The circumstances of the statues-riot provided him with the opportunity to articulate this role to his audience. In his evangelistic drama, John clearly expressed his rhetorical vision of the church's mission in the world. In a pagan environment, believers were responsible for preventing crisis by correcting the ungodly members of the community. When the community was embrolled in conflict and distress, Christians were to demonstrate their faith through prayer, perseverance, and converting others to the truth. In 
John's rhetorlcal vision the identitles of insiders and outsiders were clearly portrayed. He answered the question of "What" the purpose of the church was, gave his listeners a new sense of cultural identity, and united his followers into a spiritual army ready to face the common enemy in a pagan world.

In assessing John's strengths as a communicator I have concluded that he demonstrated effectiveness as a commentator, interpreter, and rhetorician. John succeeded as a commentator-gatekeeper in keeping his congregation informed of what was taking place in Antioch. In this sense he functioned as a stablizing force in the midst of chaos. Rhetorically, he went far beyond the details of the crisis to proclaim his interpretation of the events. John's fantasy themes were vivid and forceful. By contrasting God and the Devil, good and evil, heaven and hell, the rich and poor, and insiders and outslders John created a coherent vision of reality. Heroes and villians were easily identifiable. Earthly events took on cosmic proportions. John's fantasy themes seemed to offer simple and persuasive answers to life's complex problems. I also concluded that judged by the standards of the fourth century, John sklllfully employed the rhetorlcal devices of invention, arrangement, style, and delivery to gain and hold the attention of his audience.

In my critical analysis of his homilies, I also identified a number of significant weaknesses in John's crisis preaching. These weaknesses were discussed under the two categories of internal contradictions and divisiveness as a result of his rhetoric. Five 
rhetorical contradictions became apparent in my research of John's homilies.

First, and most obvious, was his own view of crisis. Although he verbally stated his desire to see the crisis end quickly, John needed the crisis to give force to his rhetorical appeals. The terror of riot and the resulting fear of Antioch's citizens served to sustain John's dramatic themes. John needed to preserve the crisis, or at least its memory, in order to motivate the church to further reform and social action.

Secondly, John created a vision of perfection that was unattainable for his audience. His offer of mercy and forgiveness was always just out of reach of his listeners. John continued to fuel his rhetoric of reformation with their moral failures and spiritual apathy.

John's vision of the church was also tarnished with a stark inconsistency. According to John, the church was to accomplish its holy purpose of soclal transformation by forcing others to conform to its beliefs. Rather than following Christ's sacrifical pattern of service, John belleved that violent means were justified in reaching his goal of a Christian society.

A fourth inconsistency was observed in John's use of abusive rhetoric. He appealed to his audience to avold slanderous speech and to practice care in their verbal communication. At the same time, John enjoyed attacking and denouncing his opponents with a variety of half-truths, innuendos, and falsehoods. He certalnly falled to practlce what he demanded of his audience. 
Finally, I ralsed the issue whether John was more concerned with rhetorical effect than he was with presenting the truth. John must be criticized for slanting his portrayal of historical events. Reading his homilies, one might conclude that the Christians had saved the city while the pagans were running in fear. From parallel accounts of the crisis it can be determined that this was clearly not the case. John seemed to find nothing wrong with distorting the facts, or even lying, if the goal was a righteous one.

I have concluded that John's rhetorical vision, complete with vivid stereotypes and rigid dichotomies, must have contributed to further misunderstanding and prejudicial behavior among Christians. Perhaps his call to "Christian combat" helped to plunge Antioch into the events of the riot. Of that possibility I cannot be certain. Unfortunately, the "golden-mouthed" did nothing to help and heal the social, political, and religious unrest of the Antiochenes. His eloquent rhetoric served only to polarize, rather than unify the citizens of the city.

Any honest attempt to reconstruct Chrysostom's story, or to evaluate his "golden" rhetoric, must consider these weaknesses alongside of the historical tributes that herald his communication skills. 
SOME IMPLICATIONS OF THIS STUDY

In the course of my analysis of the crisis rhetoric of John Chrysostom, four significant implications have surfaced. In this section I briefly consider these possible implications as follows: 1) the relationship of crisis to rhetoric, 2) the interpretation of history, 3) the relationship of church and state, and 4) the vision of the preacher.

\section{The Relationship of Crisis to Rhetorlc}

The results of this study certainly underscore the essential link that exists between times of crisls and great oratory. The words of Ralph Waldo Emerson, quoted in the introduction, have been supported: "Times of eloquence are times of terror." Events leading to public panic, as well as times of community or national fear concerning the future, combine to create a powerful need for someone to speak to the issues. Such circumstances also assure the presence of an audlence that is often desperately looking to find answers for how to live through such times of unrest. The responsible civic or religious leader will be expected to respond to the crisis. The skillful, albeit unethlcal speaker, can take advantage of such a vulnerable moment to present simplistic, even dangerous, solutions to the masses.

I have also suggested some other possible connections between crisis and rhetoric. Rhetoricians do not only speak after problems have arisen, they speak prior to those events as well. Eloguent, but 
divisive, rhetoric can incite passions that explode in social unrest, mob action, and tragic injury. It is important to recognize that such rhetoric may be a significant factor in precipitating crises.

Because of the strong bond between crisis and rhetoric, the speaker may be tempted to subtly nurture and sustain the unrest in order to keep the crowds in attendance. If the crisis is speedily resolved, the communicator may direct his or her energles to commemorating the event in order to keep alive, for the audience, that sense of urgency that will result in the desired action.

These potentially inappropriate and manipulative uses of crisis by the rhetorician are concerns that have been raised by my study of Chrysostom. The influential politician, clergyperson, or public speaker, must exercise care in avolding these dangers.

\section{The Interpretation of History}

In researching the life and rhetoric of John Chrysostom, I have discovered an interesting phenomenon in the area of historicalcritical studies. Generally, the ancient historians were rather candid in their analysis of John's rhetoric. Even the ecclesiastical historians of John's day were quick to criticize his abusive style. over the centuries the pattern changed. The martyred rhetorician grew larger than life. Many of John's recent biographers have simply rehearsed the story of his great character and eloguent rhetoric. By failing to critically analyze the primary sources of the fourth and fifth centuries, they contributed to the formation of the chrysostom myth. As a result, John became a fantasy theme hero for the church. 
His name became a rhetorical cue symbolizing the epitome of great preaching. Certainly these biographers were not the first, nor will they be the last, to selectively portray a favorite "saint" out of the past. Their error focuses attention on the danger of the historian seeing what he wants to see in the records of the past. No researcher can maintain total objectivity; however, it is essential that the scholar work with the primary materials of the time period.

\section{The Relationship of church and state}

The end of the fourth century was a time of tremendous change for both the church and the Roman Empire. Supported by the power of the state, the church had gained the upper hand against paganism. Likewise, imperial leaders were becoming increasingly dependent upon the approval of ecclesiastical leaders. John's rhetorical career clearly reflected the intrigue, conflict, and compromise that resulted from such an alliance of the sacred and the secular. One could easily argue that the unholy marriage was detrimental to both partners.

This writer believes that there is an important lesson to be learned from this period in history. American contemporary culture is as pluralistic as that of ancient Antioch. There are certainly those within the present Christian community, who like the ancient priest, would relish the opportunity to force their spiritual agenda upon this religiously diverse society. These individuals would gladly welcome the enthronement of a new Holy Christian Emperor who would have the political influence to enact religious legislation. The evidence of the fourth and flfth centuries seems, to this writer, to provide an 
Important warning to those of the extreme religious rlght who seem motivated by just such zeal for political control. By joining hands with the state, the church was weakened in character. Its new strength was only an lllusion that quickly became a mask for corruption and vicious plays for power. Also, the "holy" crusades which have historically resulted from such alliances have been traglcally destructive in terms of individual freedoms.

Ironically, Chrysostom's rhetoric was at one time admired and promoted by the imperial authorities. In the end, however, he was a victim of the same political games that vaulted him into power, His refusal to serve as a puppet or mouthpiece for the Emperor contributed to his demise. It must also be remembered that his undoing was spearheaded by another bishop who felt his political voice was being threatened by the upstart priest from Antioch. His political and religlous conflicts and eventual martyrdom clearly reveal the inherent inconsistency and danger of expecting that the state and church can or should sit together in the seat of government.

Implicit in this conclusion is the further warning of what can happen when the members of a religious organlzation blindly accept as divine authority every word of their leaders. Then followers cease to think for themselves and readily buy the rhetorical vision being sold by their speakers the results can be as tragic as prejudice, murder, or mass suicide. 
The Vision of the Preacher

My analysis of the crisis rhetoric of John Chrysostom also raises some important issues concerning the rhetorical visions of contemporary preachers. By virtue of their prophetic role, preachers raise issues, clarify options, and promote a world view. Like their ancient predecessor, they create and dramatize various spiritual fantasy themes in their zeal to communicate truth. Many of John's themes have been rephrased and echoed throughout church history. These themes, as well as many others, still surface in religious rhetoric as preachers attempt to explain the crises and complexities of 1 ife to their modern parishioners.

It is not my purpose to systematically pass judgment on the appropriateness of these various themes. I would, however, suggest that preachers need to be aware of the themes that comprise their own rhetorical visions. They need to consider the possible impact their dramatized messages and proclamations of "reality" will have upon a trusting audience. This writer believes that the priest/preacher must exercise care in selecting and emphasizing themes that promote understanding and peace rather than espousing those which foster stereotypes or fuel prejudices. The Christian rhetoriclan would do well to remember the words of Jesus, "Blessed are the peacemakers." In addition to this concern, the priest/preacher must also ask whether his vision encourages disagreement and dialogue or stifles creative thought. Is the speaker threatened by those who would raise questions concerning his conclusions? Are all who would dissent viewed as heretics? Are threats and scare tactics used to arouse fear 
and guilt. Is the preacher encouraging the development of a tight little religious kingdom over which he or she can rule with complete power and authority? The contemporary preacher would do well to explore these questions carefully in order to avoid some of the inconsistencies and abuses observed in the life and rhetoric of Chrysostom.

In this section I have proposed some possible implications arising out of my study of the crisis rhetoric of John Chrysostom. I have identified and briefly discussed the following important issues: the crucial relationship of times of crisis to rhetorical expression, the critical task of doing primary historical research, the danger of the church becoming entangled in matters of the state, and the necessity of the contemporary preacher exploring the dynamics of his or her own rhetorical vision.

\section{SUGGESTIONS FOR FURTHER STUDY}

As a result of my research into the crisis rhetoric of Chrysostom, I would recommend that additional studles be undertaken in the following areas: 1) primary research focused on Chrysostom's rhetoric, 2) fantasy theme analysis of contemporary preachers, and 3) preaching in the context of crisis.

\section{Further Research Concerning the "Golden-mouthed"}

I believe that there is need of a fresh English translation of some of Chrysostom's homilies. The reader who has examined John's quoted materials in this study has probably struggled to follow the 
cumbersome and dated language style of the translator. Such translation work might be combined with a thorough critical analysis of one of John's themes as reflected throughout his entire rhetorical career. For example, one might focus on John's dramatized vision of the church in society, or investigate his portrayal of the Imperial state from his first sermonic attempts through to his exile.

\section{Eantasy Themes in the Contemporary Pulpit}

I found the framework of fantasy theme analysis to be an extremely helpful critical tool in identifying Chrysostom's themes and in understanding the social dynamics of his rhetorical vision of the world. Comparative studies might also be conducted in relationship to modern preachers with significant followings. It would be fascinating to apply the fantasy theme framework of analysis to selected sermons by Billy Graham, Oral Roberts, Robert Schuller, or any of a number of other possible Christian, Jewish, Islamic, or cultic speakers. For example, one might explore the dramatized messages of one of the contemporary gurus of the new age movement in order to identify the components of their rhetorical vision.

\section{Crisis Preaching}

I believe it would also be valuable to analyze religious rhetorlc that has been delivered in the context of contemporary crises. For example, one might compare and contrast speakers from a variety of religious persuasions regarding their rhetorical response to a significant event such as the assassination of President Kennedy, Watergate, the shuttle tragedy, or the AIDS epidemlc. One might also 
explore the rhetoric of television evangelists Baker or swaggert before and then after their "sins" became public. Rhetorical responses to the present crisis of integrity surrounding well-known religious figures offers another possible topic for research.

These suggestions will hopefully stimulate the creativity of the reader who is interested in pursuing the study of religious crisis rhetorlc, whether in the fourth or twentleth centuries. Such research not only opens the door on the past but provides the scholar with the opportunity to explore his or her own rhetorical visions of $\mathrm{l}$ ife and faith. 


\section{REFERENCES}

\section{Primary Sources}

Chrysostom, John. On The Priesthood: Ascetic Treatises; Select

Homilies and Letters; Homilies on The statues. Translated by

W.R.W. Stephens in Vol. 9 of The Nicene and Post-Nicene

Fathers. Ed. Philip Schaff. 14 vols. Grand Rapids, Michigan:

Eerdmans Publishing Company, 1978.

\section{Secondary Sources}

Ammianus Marcellinus. The Surviving Books of the History of Ammianus

Marcellinus. Translated by John C. Rolfe in Ammianus

Marcellinus. 3 Volumes. Cambridge, Massachusetts: Harvard

University Press, 1935.

Eunapius. The Lives of the Philosophers. Translated by wilmer c.

Wright in philostratus and Eunapius. Cambridge, Massachusetts:

Harvard University Press, 1921.

Eusebius. The Life of Constantine. Translated by Arthur Cushman

McGiffert in The Nicene and Post-Nicene Fathers. Vol. I-

2nd Series. Grand Rapids: Eerdmans Publishing Company, 1952.

Libanius. Selected Orations. Translated by A.F. Norman in Libanius:

Selected Works. Cambridge, Massachusetts: Harvard University Press, 1977. 
Palladius. Dialogue on the Life of Saint John Chrysostom.

Translated and edited by Robert T. Meyer in Vol. 45 of

Ancient Christian Writers. Edited by Johannes Quasten, Walter

Burghardt, and Thomas Lawler, 46 vols. New York: Newman Press, 1985.

Philostratus. The Lives of the Sophists. Translated by wilmer C.

Wright in Rhilestratus and Eunaplus. Cambridge, Massachusetts:

Harvard University Press, 1921.

Socrates Scholasticus. Ecclesiastical History. Translated by A.C.

Zenos in Vol. 2 of The Nicene and Post-Nicene Fathers. 14 vols.

New York: Christian Literature Company, 1890.

Sozomen. Ecclesiastical History. Translated by A.C. Zenos in Vol. 2 The Nicene and Post-Nicene Fathers. 14 vols. New York:

Christian Literature Company, 1890.

2osimus. Historia Nova. Translated by James J. Buchanan and Harold

T. Davis. Texas: Trinity University Press, 1967.

\section{Special Works on Chrysostom}

Ameringer, T.E. "The stylistic Influence of the second sophistic on

the Panegyrical sermons of St. John Chrysostom." Diss.

Washington D.C.: Catholic University of America, 1921.

Attwater, Donald. St. John Chrysostom. Pastor and Preacher.

London: Harvill Press, 1959.

Baur, Chrysostomus. John Chrysostom and His Time. Translated by M. Gonzaga. 2 Vols. Westminster, Maryland: Newman Press, 1959-1960. 
Burns, Mary Albania. Saint John Chrysostom's Homilies on The

Statues. Washington D.C.: Catholic University of America, 1930.

Perthes, Frederic. Life of John Chrysostom. Boston: John P. Jewett and Company, 1854.

Sawhill, J.A. "The Use of Athletic Metaphors in the Biblical Homilies of St. John Chrysostom." Diss. Princeton, 1928.

Wilken, Robert L. John Chrysostom and the Jews. Los Angeles: University of California Press, 1983.

Willey, John. Chrysostom: The Orator. Cincinnati: Jennings and Graham, 1906.

\section{Special Works on Antioch}

Downey, Glanville. Ancient Antioch. New Jersey: Princeton University Press, 1963. - Antioch in the Age of Theodosius The Great. Norman, Oklahoma: University of Oklahoma Press, 1962.

Liebeschuetz, J.H.W.G. Antioch. Oxford: Clarendon Press, 1972. Pack, Roger, studies In Libandus and ant lochene soclety under Theodosius. Menasha, Wisconsin: George Barita, 1935.

\section{General Works}

Baldwin, Charles Sears. Medieval Rhetoric and Poetic. Gloucester, Massachusetts: Peter Smith, 1959.

Bowder, Diana, ed. Who Was who in the Roman World. Ithaca, New York: Cornell University Press, 1980. 
Cloonan, John. "The Effect of Classical Rhetoric upon Christian Preaching During the 1st-5th Centuries A.D." Diss. Pennsylvanla: Pennsylvanla state Unlverslty Graduate school, 1959.

Hatch, Edwin. The Influence of Greek Ideas on Christianity. New York: Harper and Row Publishers, 1957.

Holum, Kenneth G. Theodosian Empresses. Los Angeles: University of California Press, 1982.

Jones, A.H.M. The Later Roman Empire. Baltimore: Johns Hopkins Universisty Press, 1986.

Kennedy, George. Greek Rhetoric Under Christian Emperors.

Princeton, New Jersey: Princeton University Press, 1983. Quasten, Johannes. Patrology III. The Golden Age of Greek Patristic Literature. Westminster, Maryland: Christian Classics Inc., 1983.

Young, Frances. From Nicaea to Chalcedon. Philadelphia: Fortress Press, 1983.

\section{Works on Rhetorical Criticism}

Aristotle, Rhetoric. Translated by Rhys Roberts in The Rhetoric and Poetics of Aristotle. Introduction by Edward P.J. Corbett. New York: The Modern Library, 1984.

Andrews, James R. The Practice of Rhetorical Criticism. New York: Macmillian Publishing Company, 1983. 
Bales, Robert F. Interactive Process Analysis: A Method for the study of Smal1 Groups. Cambridge, Massachusetts: AddisonWe iley, 1950.

Black, Bdward. Rhetorical Criticism-A study in Method. New York: Macmillian Publishing Company, 1965.

Bormann, Ernest G. The Force of Fantasy. Carbondale: Southern Illinois University Press, 1985.

Brock, Bernard L; Scott, Robert L., eds. Methods of Rhetorical

Criticism. Detroit: Wayne st. University Press, 1972.

Thonssen, Lester; Baird, A. Craig; and Braden, Waldo w. Speech

Criticism. Second Edition. New York: The Ronald Press Company, 1970.

Tucker, Raymond; Weaver, Richard L. II; and Berryman-Fink, Cynthia. Research in Speech Communication. New Jersey: Prentice Hall, 1981.

\section{Journal Articles}

Bormann, Ernest. "Fetching Good out of Evil: A Rhetorical Use of Calamity." Quarterly Journal of Speech 63 (April 1977): $130-139$.

"Fantasy and Rhetorical Vision: The Rhetorical Criticism of Social Reality." Quarterly Journal of Speech 58 (1972): 396407.

Browning, Robert. "The Riot of A.D. 387 in Antioch." Journal of Roman studies 42 (1952): 13-20. 
Carter, Robert. "Saint John Chrysostom's Rhetorical Use of the Socratic Distinction Between Kingship and Tyranny." Traditio 14 (1958): $367-371$.

Coleman-Norton, Raul R. "Saint Chrysostom's Use of the Greek Poets." Classical Phllology 27 (1932): 213-221.

Cox, James. "Eloquent...Mighty in the Scriptures: Biblical Preachers from Chrysostom to Thielicke," Review and Expositor 72 (1975): 189-201.

Goodrich, Laurence. "Chrysostom, King of Preachers." Quarterly Journal of Speech 24 (February 1938): 27-35.

Gronbeck, Bruce E. "Dramaturgical Theory and Criticism: The State of the Art (or Science?)" Western Journal of Speech communication 44 (1980): 315-330.

Hubbell, Harry M. "Chrysostom and Rhetoric." Classical Philology 19 (1924): 261-276.

Jones, A.H.M. "St. John Chrysostom's Parentage and Education." Harvard Theological Review 46 (1953): 171-173.

Lantz, William. "Rhetoric and Theology- Incompatible?" Journal of Western Speech 19 (March 1955): 77-82.

Pack, Roger. "Two Sophists and Two Emperors." Classical Philology 42 (January 1947): 17-20.

Sedgwick, W.B. "The Origins of the Sermon." Hibbert Journal 45 $(1947): 158-164$.

Williams, Pericles S. "The Attitude of the Three Hierarchs Towards Knowledge and Learning." Greek Orthodox Review 24 (Spring 1979): 43-57. 
APPENDIX

\begin{tabular}{|c|c|c|c|c|c|c|}
\hline & 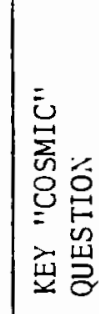 & 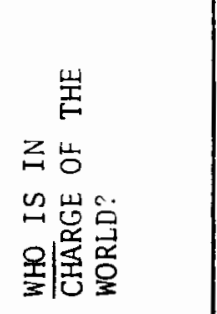 & 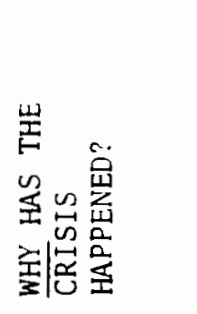 & 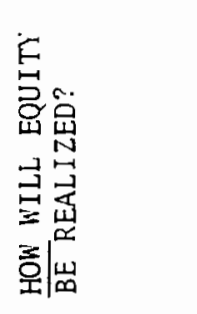 & 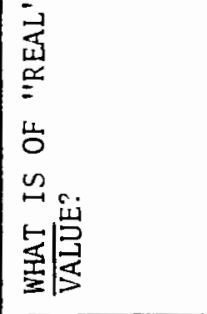 & 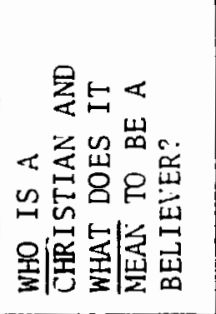 \\
\hline 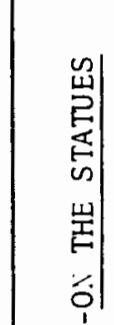 & 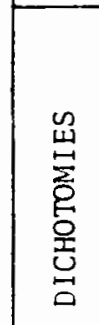 & $\begin{array}{l}\overrightarrow{5} \\
\dot{\vec{u}} \\
\dot{9} \\
\dot{8}\end{array}$ & 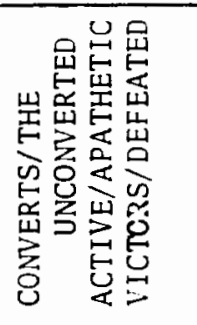 & 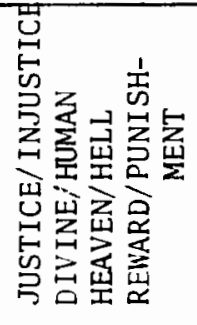 & 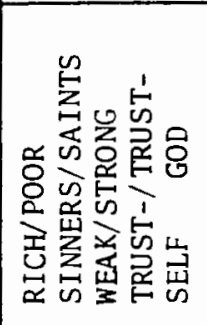 & 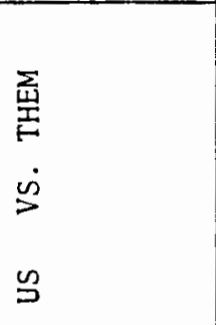 \\
\hline 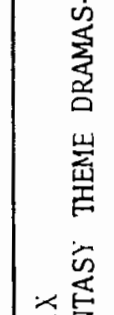 & 点岩 & 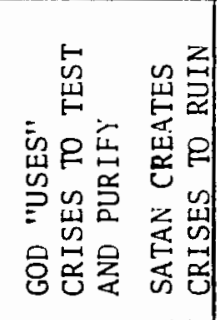 & 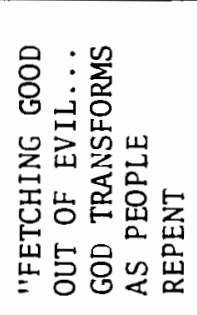 & 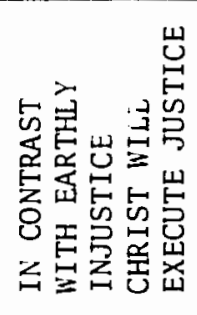 & 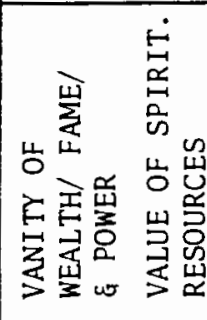 & 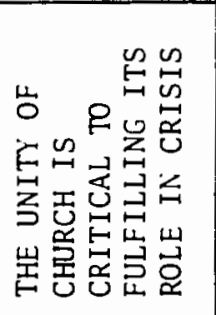 \\
\hline 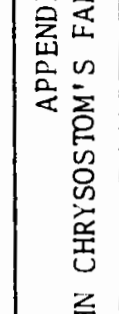 & 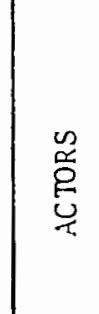 & 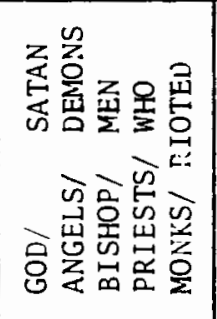 & 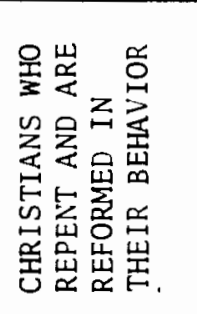 & 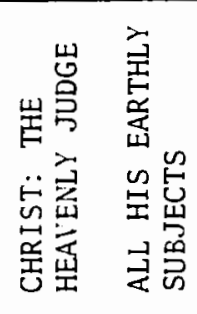 & 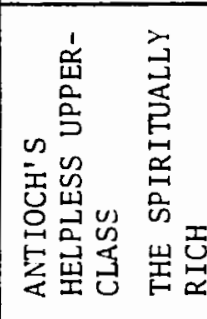 & 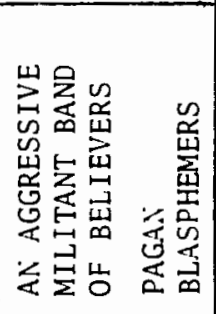 \\
\hline 立 & 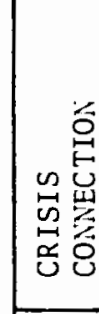 & 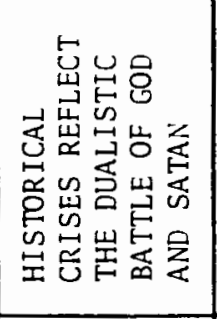 & 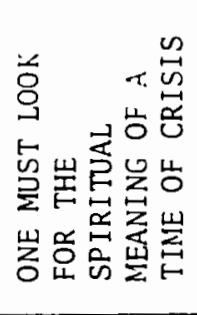 & 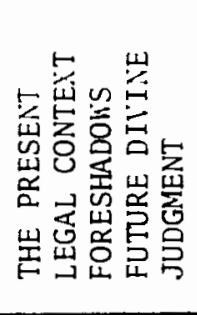 & 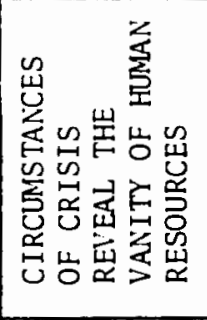 & 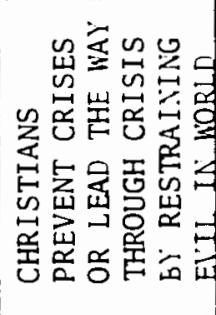 \\
\hline & 慈意 & 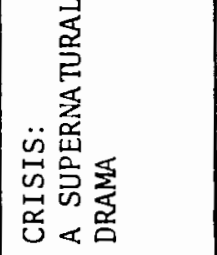 & 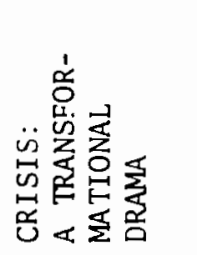 & 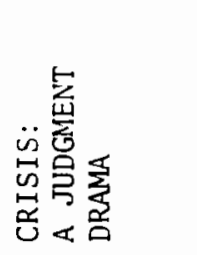 & 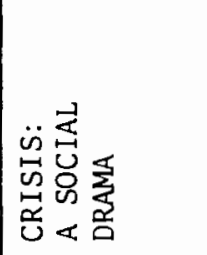 & 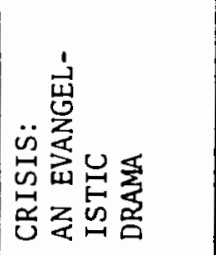 \\
\hline
\end{tabular}

